Maurice A. Deane School of Law at Hofstra University Scholarly Commons at Hofstra Law

Hofstra Law Faculty Scholarship

2002

\title{
The Constitution as Family Arbiter: A Moral in the Mess?
}

Janet L. Dolgin

Maurice A. Deane School of Law at Hofstra University

Follow this and additional works at: https://scholarlycommons.law.hofstra.edu/faculty_scholarship

\section{Recommended Citation}

Janet L. Dolgin, The Constitution as Family Arbiter: A Moral in the Mess?, 102 Colum. L. Rev. 337 (2002)

Available at: https://scholarlycommons.law.hofstra.edu/faculty_scholarship/491

This Article is brought to you for free and open access by Scholarly Commons at Hofstra Law. It has been accepted for inclusion in Hofstra Law Faculty Scholarship by an authorized administrator of Scholarly Commons at Hofstra Law. For more information, please contact lawcls@hofstra.edu. 


\title{
THE CONSTITUTION AS FAMILY ARBITER: A MORAL IN THE MESS?
}

\author{
Janet L. Dolgin*
}

Tro interconnected social upheavals that occurred in the second half of the twentieth century underlie an intensifying legal debate about the conception of family. First, Western culture openly challenged a set of assumptions that supported a vision of family as hierarchical, holistic, and almost completely separate from the marketplace. Second, a group of social institutions (including schools, churches, and voluntary communal groups) that once anchored moral debate began to recede in significance. To these upheavals, American law has increasingly responded by eliding traditional legal responses to family issues and by seeking moral direction from constitutional principles. The second of these responses has been problematic, since constitutional jurisprudence, committed to autonomous individuality, is not well suited to resolving an important question central to the debate about family: the extent to which family relationships that involve children should value autonomous individuality. In attempting to answer this question, constitutional jurisprudence has produced significant social and legal confusion, as this Article shows through analysis of Troxel v. Granville, a 2000 Supreme Court decision that involved a challenge to a state nonparental visitation statute.

\section{INTRODUCTION}

Increasingly, Americans debate the parameters of the family and the meaning of childhood. While the debate is not entirely new, it is occurring in a substantially new environment. In earlier times a series of social institutions anchored moral debate generally and the debate about family matters more specifically. These institutions included schools, churches, communal groups-and the family itself. As these institutions have changed, and to a significant degree withered, in the years following World War II, Americans have turned to the law-not only to resolve particular disputes about familial matters, but far more generally and significantly, to define familial relationships and to help construct new familial forms. But the task is beyond the capacities of most judges, themselves uncertain about the dimensions of the domestic sphere. As a result, litigants, torn by the complicated strains of domestic turmoil, and judges, confused about how to respond, have sought answers in the Constitution. These appeals to the Constitution have been facilitated by shifts in constitutional jurisprudence during the second half of the twentieth century

* Maurice A. Deane Professor of Constitutional Law, Hofstra University School of Law, Visiting Professor of Law, Benjamin N. Cardozo School of Law, Yeshiva University. B.A. Barnard College; Ph.D. Princeton University; J.D. Yale Law School. 1 am grateful to Connie Lenz, Assistant Director, Law Library, Hofstra University School of Law, for her unfailingly intelligent and generous assistance, and to Professor Mark Movsesian for his insightful comments on an earlier draft of this Article. 
that established a doctrinal ground for applying due process and equal protection rights to challenge family laws. ${ }^{1}$

Unfortunately, constitutional jurisprudence is largely inadequate to the task of discerning the proper scope of familial relationships. In particular, constitutional principles do not respond adequately to the conundrum at the center of the social debate about family. That conundrum, a product of the transformation of the domestic arena from a universe of status to a universe of contract, ${ }^{2}$ is reflected in the continuing reluctance of society to redefine children (and thus the parent-child relationship) through the terms of a universe based in contract. That universe, committed to the presumption of autonomous individuality, is unable to provide for groups (such as children) defined through status. Constitutional rules are of little help in clarifying social confusion about the family because they presume individual autonomy. As a result, they have failedand will likely continue to fail-to satisfactorily resolve cases that question the scope of childhood and the meaning of the parent-child relationship. Constitutional rules are thus unable to protect children directly as long as childhood is understood as a status, presuming age as the determinant of a vulnerable and innocent stage of life.

Even a cursory review of Supreme Court decisions involving familial matters suggests the character and extent of the problem. In one set of cases, the Court has spoken coherently and strongly in protection of the intimate choices of adults in families. These cases, mostly concerned with reproductive decisions, generally invoke the Due Process or Equal Protection Clause of the Fourteenth Amendment to protect individuals' choices. But in a second set of cases, implicating children and the relationship between children and their parents, the Court has been far more confused and hesitant. In some of these cases involving children, the Court has wavered between defining children as individuals (at least for certain purposes) and presumptively catering to their interests through the notion that their parents will best effect their welfare. At the same time, however, in other cases involving children-including Troxel v. Granville, ${ }^{3}$ considered at length in this Article-the Court has presumed childhood to be and to remain a status, declaring, in effect, that the Constitution requires the state to recognize (and then largely exit from) a universe of status so that parents-properly in charge of that universe-can govern it as they see fit.

Part I of this Article provides historical background, describing the advent and development of the so-called "traditional" family at the start

1. See Eva R. Rubin, The Supreme Court and the American Family 13 (1986) (noting significance of Brown v. Board of Education, 347 U.S. 483 (1954), in initiating this process).

2. See Henry Sumner Maine, Ancient Law 163-65 (Beacon Press 1963) (1861) (noting the gradual replacement of status relationships with contractual ones); see also infra Part I (discussing transformation of the family).

3. 530 U.S. 57 (2000). 
of the nineteenth century. Part II delineates the evolution of the socalled "modern" family, a product of the extension to the domestic sphere of the central values of the nineteenth-century marketplace. Part II further suggests that the weakening of a set of institutional moral arbiters (including schools, churches, and voluntary communal groups) has exacerbated social perplexity about the scope of family life. Part III considers alterations in the law as the legal system has responded to transformations in the family. By the last decades of the twentieth century, the erosion of communal anchors compelled family litigants, and society more generally, to seek from legal institutions guidance that would once have been provided by educators, peers, and priests. Increasingly, federal courts, including the Supreme Court, have been called on to resolve family disputes by applying constitutional principles. Parts IV and V analyze Troxel in order to illuminate the confusions that underlie efforts to resolve questions about the parameters of family relationships through constitutional principles. Part IV supplies background about the case, and Part V focuses on the inadequacy of the Court's response to the issues presented in Troxel. Finally, Part VI considers the implications of Troxel for lower courts and legislatures considering nonparental visitation.

In sum, this Article argues that constitutional law has rarely provided a suitable tool for understanding family relationships, and that its limitations become increasingly transparent as society becomes less and less certain about how to evaluate the changing contours of the domestic sphere.

\section{I. "Traditional" Understandings of Family: The Roots of the Contemporary "Debate About Family"}

The contemporary "debate about family" reflects both a complicated yearning for an earlier time widely presumed to have been free of the problems ${ }^{4}$ that now beset American families and their children, ${ }^{5}$ and a

4. These problems range from comparatively benign to genuinely terrible. They include increases in rates of divorce during the second half of the twentieth century, Barbara Dafoe Whitehead, The Divorce Culture 3 (1997), "the crack epidemic of the 1980s," Peter Applebome, Growing Pains-No Room for Children in a World of Little Adults, N.Y. Times, May 10, 1998, $\$ 4$, at 1; Peter Kerr, Addiction's Hidden Toll: Poor Families in Turmoil, N.Y. Times, June 23, 1988, at A1, and students shooting, and sometimes murdering, classmates and teachers in American schools, Timothy Egan, What Makes Kids Kill? Student Shootings Share Similar Threads, Anchorage Daily News, June 21, 1998, at F1; Butch John \& Mario Rossilli, Prosecutors Hope to Try Boyette by MidAugust, Jackson-Clarion Ledger, June 16, 1998, at 1.

5. In some part, the yearning to "return" is misplaced because the American family never uniformly reflected the portrait of family suggested by the notion of the "traditional" family. See Stephanie Coontz, The Way We Never Were: American Families and the Nostalgia Trap 2 (2000 ed.) [hereinafter Coontz, Never Were] ("Families have always been in flux and often in crisis; they have never lived up to nostalgic notions about 'the way things used to be.'”). Even in its 1950 s heyday, the traditional family was more important as an ideological matter-especially as a putative model for behavior-than it was actually reflective of behavior within American families. Coontz notes: 
broad readiness to redefine family in terms of individuality and choice. Americans perceive the debate about family to set those who value "tradition" against those who value "modernity." ${ }^{\prime}$ ln fact, however, the ideological dynamic that underlies the debate about family reflects-and depends upon-both traditional and modern visions of family and the contradictions each poses to the other. Thus, the various understandings of family are informed by each other, and each is continually reinterpreted in light of the others. In the American family, as understood and as experienced, tradition is constantly threatened by the allure of modernity (in particular, the allure of choice), and modernity is reshaped and reinterpreted to reflect the values of tradition (enduring solidarity and love). Indeed, adherents of modernity in the domestic arena also generally value traditional goals-affectionate, committed families, raising secure, happy children. ${ }^{7}$ At the same time, adherents of tradition rely on the ideological perspective of modernity (in particular, the presumption

The reality of [1950s] families was far more painful and complex than the situation-comedy reruns or the expurgated memories of the nostalgic would suggest. Contrary to popular opinion, "Leave lt to Beaver" was not a documentary.

In the first place, not all American families shared in the consumer expansion that provided Hotpoint appliances for June Cleaver's kitchen and a vacuum cleaner for Donna Stone. A full 25 percent of Americans, forty to fifty million people, were poor in the mid-1950s . . .

In the second place, real life was not so white as it was on television. . . [Television] families were so completely white and Anglo-Saxon that even the Hispanic gardener in "Father Knows Best" went by the name of Frank Smith. Id. at $29-30$.

6. The terms "tradition" and "modernity" are being used primarily to refer to the aspects of a social debate. "Tradition"-as in "traditional values" and "traditional families"-is often used to imply an enduring social unit, validated by centuries of success. In fact, this concept of traditional family developed in the nineteenth century as one aspect of the emergence of modern capitalism. In consequence, the ideological dynamic that underlies the contemporary debate about family reflects both traditional and modern visions of family and the contradictions that each vision poses to the other. See John Demos, Past, Present, and Personal: The Family and the Life Course In American History 30-31 (1986). A "new sense that the family had a history of its own" arose in that century. Id. at 30 .

7. Self-proclaimed adherents of modernity resemble self-proclaimed adherents of tradition in assessing family life through reference to nostalgic images of treasured children, nurtured by loving parents. So, for instance, Kath Weston, delineating and analyzing "gay kinship ideologies," explains:

In practice ... [a] sense of creating kinship in the absence of precedent gave way to social arrangements that were meaningfully structured and choices that were inevitably constrained. The formal criteria used to differentiate chosen kin from nonkin incorporated signs of diffuse, enduring solidarity that did not differ substantially from those featured in dominant discourse on kinship. Ideally, gay families incorporated relationships forged and tempered over the course of years. Chosen kin were expected to "be there" for one another through ongoing, reciprocal exchanges of material and emotional support.

Kath Weston, Forever Is a Long Time: Romancing the Real in Gay Kinship 1deologies, in Naturalizing Power 87, 93 (Sylvia Yanagisako \& Carol Delaney eds., 1995). 
of choice) to effect traditional ends. ${ }^{8}$ Professor Marilyn Strathern suggests a peculiar consequence:

[I] $\mathrm{t}$ would seem we cannot be at both ends of the continuum at the same time. 1 want to suggest that is exactly where we might be. The suggestion arises from an otherwise perplexing sensation. This is the sense that there seems both more "status" and more "contract" around in the world, or at least in arguments about them. Would it also follow then that one might have both more tradition and more modernity at the same time?

Even a cursory look at contemporary family law reveals that we do indeed have "both more tradition and more modernity"-and that almost everyone is confused about the implications.

The debate-and genuine confusion-about what families are, and about what they should be, cannot be understood apart from the social and economic parameters that shaped the traditional and modern understandings of family. Both are, in large part, products of an ideology ${ }^{10}$ of personhood that developed in support of modern capitalism. ${ }^{11}$ The

8. Recent state laws providing for so-called "covenant marriage" illustrate this reliance. Covenant marriage laws offer couples contemplating marriage the opportunity to choose between no-fault marriage and "covenant" marriage. See, e.g., Ariz. Rev. Stat. $\$ \S$ 25-901-25-906 (2000) (Arizona covenant marriage statute); La. Rev. Stat. Ann. $\S \S 9: 272-9: 275.1$ (West 2000) (Louisiana covenant marriage statute). Those marrying under the "covenant" provision choose before marriage to curtail the possibility of divorce. Such laws suggest that tradition can be revivified if people choose tradition over modernity. The project from the start is endangered, however, in that those making choices not inexorably anchored in some ultimate (natural or supernatural) truth can later make other, less traditional, choices. See generally Jason Andrew Macke, Of Covenants and Conflicts-When "I Do" Means More than It Used To, but Less than You Thought, 59 Ohio St. L.J. 1377, 1382-87 (1998) (describing Louisiana's groundbreaking covenant marriage statute and its roots in traditional notions of family).

9. Marilyn Strathern, Enabling 1dentity? Biology, Choice and the New Reproductive Technologies, in Questions of Cultural Identity 37, 45 (Stuart Hall \& Paul du Gay eds., 1996).

10. This Article does not use the term "ideology" to refer to a system of political beliefs. Rather, the term refers to the pervasive forms in terms of which people understand what it means to be human and in terms of which they act in the world. The definition reflects that proposed by the French anthropologist Louis Dumont, who wrote:

Our definition of ideology thus rests on a distinction that is not a distinction of matter but one of point of view. We do not take as ideological what is left out when everything true, rational, or scientific has been preempted. We take everything that is socially thought, believed, acted upon, on the assumption that it is a living whole, the interrelatedness and interdependence of whose parts would be blocked out by the a priori introduction of our current dichotomies.

Louis Dumont, From Mandeville to Marx: The Genesis and Triumph of Economic Ideology 22 (1977).

11. This Article is concerned primarily with shifting ideologies of family and with the law's responses. See supra note 10 (defining ideology). Ideological shifts inevitably reflect-and effect-economic and political changes as well as changes in social institutions. This Part sketches the connection between understandings of family and the economic, political, and social universe within which families operate. It is not intended to provide a detailed history of the family. Useful historical accounts of the American family 
traditional family, as constructed during the early years of the Industrial Revolution, was defined in express contrast to the world of the marketplace. ${ }^{12}$ As the marketplace was associated with money, choice, and negotiation, and was understood to be populated largely by men, ${ }^{13}$ so the home was associated with love, sacred truths, and self-sacrifice, and was identified with women and treasured children. ${ }^{14}$ The nineteenth-century home and that of the first half of the twentieth century were understood as sanctuaries from the tensions of the marketplace. ${ }^{15}$ The traditional home contained the nuclear family, ideally composed of a working husband-father, a stay-at-home wife-mother, and their children. ${ }^{16}$ The an-

include: Stephanie Coontz, The Social Origins of Private Life: A History of American Families 1600-1900 (1988) [hereinafter Coontz, Social Origins]; Demos, supra note 6; Michael Grossberg, Governing the Hearth: Law and the Family in Nineteenth-Century America (1985); Steven Mintz, A Prison of Expectations: The Family in Victorian Culture (1983).

12. See Demos, supra note 6 , at 30-31 (describing contrast between home and work as an "adversary relation").

13. Poor women and children did work in the marketplace of the nineteenth and early twentieth centuries. Both groups provided sources of cheap labor for the industrial enterprise. See Viviana A. Zelizer, Pricing the Priceless Child: The Changing Social Value of Children 5-6 (1985) (stating that poor children remained economically valuable to their families during the nineteenth century, while middle-class and richer children were redefined as part of the "nonproductive world of childhood"). By the nineteenth century, middle-class mothers and children were expected to work only at home (or at school). As Steven Mintz and Susan Kellogg explain:

By the middle of the nineteenth-century, the older pattern in which husbands, wives, and children worked together as participants in a common economic enterprise had been replaced by a new domestic division of labor. The middleclass husband was expected to be the breadwinner for the family. Instead of participating in domestic industries, the middle-class wife was expected to devote herself full-time to keeping house and raising children.

Steven Mintz \& Susan Kellogg, Domestic Revolutions: A Social History of American Family Life 50 (1988).

14. Mintz \& Kellogg, supra note 13, at 43-65 (characterizing role of women and children in nineteenth century home). Women were understood as inherently nurturing, as ideally self-effacing, and as the backbone of the domestic sphere. During the nineteenth century, popular women's magazines described women as "forming the future patriot, statesman, or enemy of his country, [but] more than this, . . sowing the seeds of virtue or vice which will fit him for Heaven or for eternal misery." Mary Ann Mason, From Father's Property to Children's Rights: The History of Child Custody in the United States 52-53 (1994) (citing Maxine L. Margolis, Mothers and Such: Views of American Women and Why They Changed 33 (1984)).

15. Demos, supra note 6 , at 31 (describing home and family as refuge and "fortification" against outside dangers).

16. Stephanie Coontz describes the development of middle-class family morality in the mid-nineteenth century as having focused on the family as "a 'sanctuary,' an 'oasis,' an 'ivory tower,' [and] a moated 'castle" "-a universe centered around women who reminded men that "there [were] objects more elevated, more worthy of pursuit than wealth' and that these were under the care of women." Coontz, Social Origins, supra note 11, at 210-11 (quoting, with respect to second quotation, statement of Josepha Hale quoted in Nancy Cott, Bonds of Womanhood 68 (1977)). Coontz further explained that " $[t]$ he secular middle-class family [of the mid-nineteenth century] was increasingly cut off from 
thropologist David Schneider, who studied American kinship during the mid-twentieth century, described the American family as a cultural system based on the dichotomy between home and work:

The set of features which distinguishes home and work is one expression of the general paradigm for how kinship relations should be conducted and to what end. These features form a closely interconnected cluster.

The contrast between love and money in American culture summarizes this cluster of distinctive features. Money is material, it is power, it is impersonal and unqualified by considerations of sentiment or morality. Relations of work, centering on money, are of a temporary, transitory sort ....

... Money is material, but love is spiritual. The spiritual quality of love is closely linked with the fact that in love it is personal considerations which are the crucial ones. ${ }^{17}$

Sir Henry Maine, writing a century earlier, captured the distinction as part of an explanation of a historic shift from a world that values status-a world in which inherent rights and duties reflect inexorable truths-to a world that values contract-a world in which putatively equal autonomous individuals are expected to negotiate the terms of their own everyday lives, increasingly unharnessed by the dictates of status and tradition. ${ }^{18}$ Maine believed:

The movement of the progressive societies has been uniform in one respect. Through all its course it has been distinguished by the gradual dissolution of family dependency and the growth of individual obligation in its place. The individual is steadily substituted for the Family, as the unit of which civil laws take account. . . . Nor is it difficult to see what is the tie between man and man which replaces by degrees those forms of reciprocity in rights and duties which have their origin in the Family. It is Contract. Starting, as from one terminus of history, from a condition of society in which all the relations of Persons are summed up in the relations of Family, we seem to have steadily moved toward a phase of social order in which all these relations arise from the free agreement of individuals. ${ }^{19}$

public intercourse, not just conceptually but also physically. Specialized rooms emphasized the separation of family members from tradesmen and casual visitors." ld. at 231.

17. David M. Schneider, American Kinship: A Cultural Account 48-49 (2d ed. 1980). Schneider states that the goal of his work is to describe American kinship as a "system of symbols and meanings." Id. at 8 .

18. See Maine, supra note 2 , at 109-65.

19. Id. at 163. 
Although Maine's work has been discredited as a historical account, ${ }^{20}$ it does describe the contrasting notions around which the ideology of his own time was constructed and effected.

The family that Maine assumed, and that Schneider studied and described, differed from the marketplace not only in reflecting-but in valuing-hierarchy and the community as a whole rather than equality and individuality. ${ }^{21}$ Within the traditional family, roles followed statuses. ${ }^{22}$ The latter were largely determined through reference to age and gender. ${ }^{23}$ Society presumed the subservience of women and children to men, and the enduring solidarity of the hierarchical whole. ${ }^{24}$ Ironically, the traditional model of family as a social unit-characterized by "[e]nduring, diffuse solidarity" 25 - was promoted most ardently and actualized most widely in the middle years of the twentieth century, just before it began visibly to collapse. ${ }^{26}$

20. See John J. Honigmann, The Development of Anthropological Ideas 141 (1976) (criticizing ethnography on which Maine relied); Peter F. Drucker, The Employee Society, $58 \mathrm{Am}$. J. Soc. 358, 358 (1953) (arguing that the modern period has witnessed the opposite move, from contract to status).

21. See, e.g., Milton C. Regan, Jr., Family Law and the Pursuit of 1ntimacy 9-10 (1993) (describing nineteenth-century family law as having "reflected a relatively strong sense that men and women within the family should act in accordance with certain standard expectations that flowed from their statuses as husbands, wives, fathers, and mothers").

22. Milton Regan described the "basic organizing principle" of nineteenth-century family law as having been "status." Id. at 6 . He further defined status as "the notion that family members had specific legal identities that were the source of relatively fixed rights and obligations." Id. Professor Regan compared this vision with that of the late twentieth century. "The law," he asserted, "is now more likely to see 'individuals' rather than husbands, wives, parents, or children, and to see 'relationships' rather than 'marriages' or 'families." Id. at 39.

23. 1d. at 6 (describing nineteenth-century family roles as "based on the assumption that men and women by nature were fit for certain distinct pursuits, an assumption with which modern society takes issue").

24. Stephanie Coontz has explained that the "definition of sex roles and family life" in the mid-nineteenth century was constructed "upon conceptions of male-female differences and oppositions between home and world that had been formulated in the early nineteenth century." Coontz, Social Origins, supra note 11, at 229.

25. Schneider, supra note 17 , at $21,51-52$ (describing American family as a locus of love, characterized by "[e]nduring, diffuse solidarity").

26. The 1950s, in Coontz's view, did provide many Americans with "a secure oasis in their immediate nuclear families." Stephanie Coontz, The Way We Really Are 35 (1997) [hereinafter Coontz, Really Are]. Moreover, during this period "family life and gender roles became much more predictable, orderly, and settled ... than they were either twenty years earlier or would be twenty years later." ld. at 36 . Coontz compares family life in the 1950s with family life in 1990, and writes:

Ninety percent of all the households in the country were families in the $1950 \mathrm{~s}$, in comparison with only 71 percent by 1990 . Eighty-six percent of all children lived in two-parent homes in 1950, as opposed to just 72 percent in 1990. And the percentage living with both biological parents-rather than, say, a parent and stepparent-was dramatically higher than it had been at the turn of the century or is today: seventy percent in 1950 , compared with only 50 percent in 1990. 
That collapse reflects a variety of social and economic forces, including the replacement of a factory-oriented economy with a service-oriented economy that operates out of offices and, by the end of the twentieth century, out of homes as well; the entry of large numbers of women into the workforce during and after World War II; the strengthening of a vocal middle class in the context of the post-War boom; and the homogenization of world culture caused by the growth of electronic media and a global economy. ${ }^{27}$ The traditional myth of family became less firmly entrenched among a generation of Americans no longer firmly committed to distinguishing the person at home from the person at work.

\section{The Transformation of Families and the Withering of Community}

Shifts in understandings of family that entered into social consciousness at the end of the twentieth century signal a quantitative transformation in the scope and meaning of domestic life. It should not, however, be assumed that in earlier decades the American family changed little or not at all. Since colonial days, American families have been changing in response to developments in the larger social and economic world. ${ }^{28}$

Nearly 60 percent of kids-an all-time high-were born into male breadwinnerfemale homemaker families; only a minority of the rest had mothers who worked in the paid labor force.

Id. at 37 .

Nonetheless, "[n]ostalgia for the 1950s," explains Coontz, "is real and deserves to be taken seriously, but it usually shouldn't be taken literally." Id. at 34 . By this she means that families of the 1950 s were "traditional" in a way they never were again, but that "traditional" entailed significant disadvantages from a contemporary perspective. For instance, gender inequality was one of the central components of the 1950 s family. Id. at 34-35.

27. See Francis Fuktyama, The Great Disruption: Human Nature and the Reconstitution of Social Order 106 (1999) (reporting that percentage of women participating in labor force in U.S. between 1960 and 1995 increased from thirty-five to fifty-five percent); Robert D. Putnam, Bowling Alone: The Collapse and Revival of American Community 282-83 (2000) (describing "nationalization and globalization" of economy); Jeremy Rifkin, The Biotech Century 177-81 (1998) (noting that print technology has been subsumed by electronic technology with respect to "organization and management of production, commerce and trade" and describing shifts in human consciousness that result from information technology); Bruce J. Schulman, The Seventies 7 (2001) (describing the strengthening middle class); Sue Shellenbarger, Latest Backlash Against Dual Earners lgnores Some Realities, in Sue Shellenbarger, Work and Family 54, 55 (1999) [hereinafter Shellenbarger, Work and Family] (reporting seven percent growth each year in "home-based self-employment"); Sue Shellenbarger, Telecommuter Profile: Productive, Efficient . . . and a Little Weird, in Shellenbarger, Work and Family, supra, at 209, 209-11 (describing "telecommuting"). Detailed consideration of the effects of these changes on the family are beyond the scope of this Article.

28. The widespread promulgation of Married Women's Property Acts during the nineteenth century represents a significant reconstruction of relations between spouses. These acts granted married women the legal right to control at least some of their separate property. See, e.g., Lawrence M. Friedman, A History of American Law 209-11 (2d ed. 1985) (summarizing development of laws granting married women rights to manage 
Some of the strains that emerge clearly today began to appear less clearly in the nineteenth century. ${ }^{29}$ Most importantly, until the end of the twentieth century, society in large part assimilated the transforming American family into the venerated model of family life, and thereby preserved an understanding of family as a unified institution that remained distinct from the world of the marketplace. ${ }^{30}$

Two related shifts in our conception of family relationships appeared in the last decades of the twentieth century and have made it increasingly difficult to preserve a conception of family as distinct from the marketplace. In consequence, these shifts have exacerbated confusion and disagreement about families. First, an evolutionary shift toward the recognition of adults within families as autonomous individuals ${ }^{31}$ became revolutionary in the last decades of the twentieth century. ${ }^{32}$ Society did not, however, comparably reconstruct its understanding of children, and it still views them as dependant and vulnerable. As a result, while society provided opportunities for adults in families to negotiate and renegotiate openly the terms of their relationships, it became increasingly difficult to provide many children with the sorts of domestic security and stability still

property). At about the same time, American law recognized legal parentage through adoption for the first time. Id. at 21I-12. Both changes represent a significant shift in earlier understandings of family as the product of fixed-status relationships. However, both changes had more limited consequences than their nature might suggest. Married women were granted the right to control their own property. Insofar as most nineteenthcentury families included working husbands and stay-at-home wives, women rarely owned property acquired during a marriage. Lawrence Friedman suggests that these acts were intended primarily to provide for creditors rather than for wives. Id. at $21 \mathrm{I}$. The availability of legal adoption also had limited consequences. Until recent decades, adoptions were rarely "open," and the families that resulted from adoption were assimilated to the model of the "blood" family. Elizabeth Bartholet, Family Bonds: Adoption and the Politics of Parenting 53-57 (1993) (describing "sealed record" tradition in American adoption law).

29. See Mintz \& Kellogg, supra note I3, at 62-63 (noting development of families based on affection by end of colonial era and development of tensions created both by disparities between women's expectations and the role of wife/mother, and by the social isolation of nuclear families).

30. As Martha Minow asserts: "Where rights appeared for individual family members [during the nineteenth century], they were constrained by the larger conception of the family sphere as removed from the realm of liberal values." Martha Minow, Making All the Difference: Inclusion, Exclusion, and American Law 271 (1990); see also supra note I7 and accompanying text (describing David M. Schneider's ethnography of American kinship at mid-twentieth century).

31. The promulgation of the Married Women's Property Acts, beginning in the midnineteenth century, illustrates this process dramatically. See Leslie J. Harris \& Lee E. Teitelbaum, Family Law 13 (2d ed. 2000); see also, e.g., Illinois Married Women's Act, 1861 Ill. Laws 1433 (providing that "all property, both real and personal, belonging to any married woman, as her sole and separate property ... shall, notwithstanding her marriage, be and remain, during coverture, her sole and separate property"), quoted in Harris \& Teitelbaum, supra, at I3.

32. See infra Part III.B (delineating changes in law's regulation of adults within families in last decades of twentieth century). 
deemed essential during childhood by a broad based group of theorists. ${ }^{33}$ In consequence, society has struggled with competing conceptions of childhood $^{34}$ and with competing models of appropriate adult authority ${ }^{35}$ Second, these revolutionary shifts in the social understanding of adults within families occurred just as the set of social institutions that had provided moral guidance to earlier generations-including churches, ${ }^{36}$ schools, ${ }^{37}$ and a variety of voluntary communal groups ${ }^{38}$-began widely to wither.

This Part first describes the development of the "modern" family. It then broadly describes the withering of communal institutions since the middle of the twentieth century and suggests some consequences of that trend for the debate about transformations in the domestic sphere.

\section{A. The Development of the "Modern" Family}

The modern family arose, in large part, from a confluence of home and work. By the I960s and 1970s, the values of the marketplace were being applied to, and were redefining, the domestic arena. ${ }^{39}$ Family members (especially adults within families) began to understand themselves as autonomous individuals, free to negotiate the terms of their relationships, and as potentially liberated from traditional family roles by the

33. See, e.g., Joseph Goldstein et al., Beyond the Best Interests of the Child 3-8 (1973) (noting significance of providing adult care for children that safeguards children's psychological, as well as physical, well-being); Jerome Kagan, The Nature of the Child 256-64 (1984) (reviewing parental mechanisms for socialization used around the world and concluding that there is a need for adult authority in directing a child's socialization); Bruce C. Hafen, Exploring Test Cases in Child Advocacy, 100 Harv. L. Rev. 435, 445-46 (1986) (book review) (disapproving of "abandon[ing] children to their rights").

34. See, e.g., Minow, supra note 30, at 287-88 (considering alternative conceptions of children, as different from adults in their need for special guidance, and as future adults who need experience in an adult world).

35. See, e.g., Bellotti v. Baird (Bellotti II), 443 U.S. 622, 634 (1979) (allowing judicial authority to displace parental authority by authorizing judges to grant permission, in lieu of parental approval, to minors to undergo abortion).

36. Alexis de Tocqueville, in his remarkable study of American government and society in the nineteenth century, concluded that religion provided an essential bulwark in America against the greatest dangers of extreme individualism. 1 Alexis de Tocqueville, Democracy In America 304-05 (Francis Bowen \& Phillips Bradley eds., Henry Reeve trans., Alfred A. Knopf 1945) (1835) [hereinafter Reeve's de Tocqueville].

37. See Neil Postman, The End of Education: Redefining the Value of School 13-18 (1995) [hereinafter Postman, Education] (describing essential ideological role of schooling in American history).

38. Sec 2 Reeve's de Tocqueville, supra note 36, at 102-05 (describing significance of "free institutions" in protecting American democratic order).

39. Bruce Schulman describes the 1970 s, a decade generally understood to represent few significant cultural initiatives, as a decade that "reshaped the political landscape .... In race relations, religion, family life, politics, and popular culture, the 1970 s marked the most significant watershed of modern U.S. history, the beginning of our own time." Schulman, supra note 27 , at xii. 
possibility of exercising choice at home, as well as at work. ${ }^{40}$ The understandings of personhood and relationship that lay beneath these new understandings of family were not themselves new. They flowed, as did understandings of the traditional family, from the broad ideological arena that empowered and reflected nineteenth-century capitalism. ${ }^{41}$ By the second half of the twentieth century, however, notions of personhood, previously associated almost exclusively with life outside the home, were appearing within the domestic arena. ${ }^{42}$ This process of ideological transformation set the stage for, and was accelerated by, an active revival of feminism, beginning at about the same time. ${ }^{43}$ During the last three decades of the twentieth century, the feminist movement, in its liberal and radical guises, presented ideological justification for the reconstruction of American family life. ${ }^{44}$

lncreases in divorce, cohabitation, unmarried parentage, ${ }^{45}$ and reproductive options (including abortion and contraception) ${ }^{46}$ suggest the extent of the shift in understandings of family relationships and the do-

40. In 1991, the National Commission on Children noted that American families have undergone "[d]ramatic social, demographic, and economic changes during the past 30 years." National Commission on Children, Final Report: Beyond Rhetoric: A New American Agenda for Children and Families 15 (1991) [hereinafter National Commission on Children, Final Report]. Most of the changes described (smaller families, one parent families, working mothers as well as working fathers, inconsistent paternal support and involvement), reflect adult choices (the choice to use contraception, to divorce or separate, to bear children outside of marriage, to work outside the home, to abandon one's children).

4I. See, e.g., Regan, supra note 21, at 35-36 (noting that "modern family law has steadily moved toward contract as its governing principle").

42. Id. at 34-35 (describing modern family law as the result of a shift from Victorian "vision of [the private realm] as an arena defined in large part by family relations to a vision of it as a zone of individual autonomy").

43. The National Organization for Women (NOW), established in 1966, aimed to "bring women into full participation in the mainstream of American society . . . in truly equal partnership with men." Schulman, supra note 27, at 164 (quoting NOW Statement of Purpose, reprinted in Betty Friedan, It Changed My Life 109 (Harvard Univ. Press 1998) (1976)). At that time, the organization worked for passage of equal rights amendments, the legalization of abortion, and laws prohibiting discrimination on the basis of gender in housing and employment. Id. Many radical feminists asked for a basic revolution in social institutions that would completely eliminate patriarchal sentiments. Id. at 11 .

44. See Kay S. Hymowitz, Ready or Not: Why Treating Children as Small Adults Endangers Their Future-and Ours 42-43, 68 (1999) (asserting connection between feminism and change in social understandings of childhood and of parent-child relationships).

Moreover, the movement of women into the workforce in the second half of the twentieth century has inevitably altered the character of family life. See Putnam, supra note 27, at 194-203 (noting possible connection between increase of women in workforce and shift in character of communal involvements).

45. See Hymowitz, supra note 44, at 195-96 (connecting cohabitation and divorce to shifts in understanding of marriage).

46. See Janet L. Dolgin, Defining the Family: Law, Technology, and Reproduction in an Uneasy Age 6-7 (1997) [hereinafter Dolgin, Defining the Family] (considering ideological implications of choices offered through reproductive technology). 
mestic arena that swept the nation in the second half of the twentieth century. Each of those changes was enabled by, or instead itself encouraged, correlative changes in family law, including the promulgation of laws providing for no-fault divorce (beginning in the late 1960s), ${ }^{47} \mathrm{ju}$ dicial recognition of prenuptial agreements, allowing a couple to provide before marriage for the terms of a potential divorce (beginning in the early 1970s), 48 decisions of the United States Supreme Court providing for the paternity of unmarried fathers (in the 1970s and 1980s), ${ }^{49}$ and a line of Supreme Court cases defining a constitutional right to make reproductive decisions (beginning in the mid-1960s). ${ }^{50}$ Increases in divorce, especially, have altered understandings of childhood and transformed many children's lives. In the context of divorce, adults' choices, justified by an ideology that values liberty and freedom within the domestic arena, ${ }^{51}$ inevitably affect children. The valuation, or simply the acceptance, of divorce has required society to reconstruct an understanding of family that associated love with lasting commitment and kin relationships with communal solidarity.

These changes have been especially discomforting to a society that sustains a commitment, at least officially, to an understanding of children as innocent and fragile ${ }^{52}$ and thus as unprepared to make and effect ba-

47. California was the first state to provide for no-fault divorce. See The Family Law Act, ch. 1608, $\$ \$ 4500,4508-4509,1969$ Cal. Stat. 3312, 3323-3325. Other states quickly followed the California model. See Doris Jonas Freed, Grounds for Divorce in the American Jurisdictions (as of June 1, 1974), 8 Fam. L.Q. 401, 421-23 (1974) (listing grounds for divorce in each state and indicating that by 1974 only Illinois, Massachusetts, Mississippi, Pennsylvania, and South Dakota had only "fault" grounds).

48. See, e.g., Posner v. Posner, 233 So. 2d 381, 384 (Fla. 1970) (upholding a prenuptial agreement while taking judicial notice of the increase in the ratio of divorces to marriages in society). Many prenuptial agreements were previously dismissed by courts as violative of public policies that favored marriage. Id. at 383.

49. See, e.g., Caban v. Mohammed, 441 U.S. 380, 394 (1979) (declaring unconstitutional New York statute that gave unwed mothers, but not unwed fathers, right to withhold consent to adoption of child); Stanley v. Illinois, 405 U.S. 645, 651 (1972) (recognizing "private interest" of an unmarried father "in the children he has sired and raised").

50. See, e.g., Roe v. Wade, 410 U.S. 113, 154 (1973) (finding limited right to abortion); Eisenstadt v. Baird, 405 U.S. 438, 443 (1972) (invalidating state prohibition on the distribution of contraceptives to unmarried individuals); Griswold v. Connecticut, 381 U.S. $479,485-86$ (1965) (describing right to family privacy and thus invalidating a state birtb control law).

51. Whitehead, supra note 4, at 184 (noting that "[p]erhaps the most alluring and most powerfully sponsored claim for divorce has been its promise of greater personal freedom"). Whitehead contrasts the ideology of "freedom" surrounding divorce with the reality of divorce for men, women, and children. ld. at 184-85.

52. See, e.g., National Commission on Children, Final Report, supra note 40, at $71-72,74,76$ (identifying society's "primary goal" as "support[ing] and strengthen[ing] families so that children's needs can be met" and noting that "children's well-being must be a primary focus of families"). The report delineates eleven principles about children's needs, parents' roles, and society's obligations that form the backbone of the Commission's proposals. These principles include the following conclusions: 
sic choices about the scope of their domestic relationships. ${ }^{53}$ The National Commission on Children, for instance, has found that "[p]arents bear primary responsibility for meeting their children's physical, emotional, and intellectual needs and for providing moral guidance and direction." 54 Yet divorce, for instance, raises complicated questions about the scope of childhood and the appropriate role for children in divorce and post-divorce domestic settings, thus challenging the assumption that children are ill served by the loss of loving kin through parental death, divorce, or separation. ${ }^{55}$ In short, the collapse of a world that supported the ideology of traditional families and the reconstruction of domestic life within ongoing families have bred widespread confusion, disagreement, ambiguity and concern.

The elaboration and intermingling of the notions of tradition and modernity have perplexed both society and the law. ${ }^{56}$ There is widespread confusion about families in general and especially about children and the implications for children of the "modern" conception of adults within families as autonomous individuals, connected only insofar as, and for as long as, they choose to be connected. Society has been hesitant to

Parents bear primary responsibility for meeting their children's physical, emotional, and intellectual needs and for providing moral guidance and direction. It is in society's best interests to support parents in their childrearing roles, to enable them to fulfill their obligations, and to hold them responsible for the care and support of their children.

... Children do best when they have the personal involvement and material support of a father and a mother and when both parents fulfill their responsibility to be loving providers.

... The family is and should remain society's primary institution for bringing children into the world and for supporting their growth and development throughout childhood. Id. at xix.

53. There are exceptions. Some voices within the so-called children's rights movement have called for new understandings of children as putatively equal autonomous individuals. Richard Farson, for instance, argues for the liberation of children. Richard Farson, Birthrights 16 (1974). He advises that children should be given freedom to engage in sexual relationships with adults and with other children, id. at 146-48, that they not be "incarcerated" in schools unless they choose to spend their time there, id. at 96-100, and that they be allowed to avoid parental influence in their everyday lives, id. at 43 .

The children's rights movement has also taken a more gentle form than that represented by Farson. See Neil Postman, The Disappearance of Childhood 139-42 (1982) [hereinafter Postman, Childhood]. In this older form, understandings of appropriate social and legal responses to children remain grounded in traditional notions of childhood as a period of fragility and innocence. ld. This form of the children's rights movement has nineteenth-century precedents, including special laws concerned with children's labor and the enactment of special criminal codes applicable to children alone. Id. at 139.

54. National Commission on Children, Final Report, supra note 40, at xix.

55. See Whitehead, supra note 4, at 129-32 (noting the need for cultural reconstruction in the wake of demographic shifts brought by divorce and nonmarital parentage).

56. See supra note 9 and accompanying text (quoting Marilyn Strathern's description of the elaboration of notions of tradition and modernity). 
redefine children similarly. Yet, the consequences for children of adults' familial choices conflict with traditional understandings of children as treasured, innocent, and vulnerable. ${ }^{57}$ For instance, lawmakers struggle, with significant confusion and uncertainty, to harmonize rules that provide for easy divorce with those designed to preserve strong, stable bonds between children and their parents. ${ }^{58}$ In attempting to mediate contradictory understandings of adults within families and of children within families, lawmakers are forced to explore and compare various models of family. ${ }^{59}$

\section{B. Erosion of Institutional Arbiters}

In their quest for answers, however, lawmakers have had to search without the aid of institutions that traditionally would have assisted in the process of defining family norms. Many of the broad social and economic changes responsible for the widespread dissolution of traditional forms of families also weakened social institutions that served as moral arbiters with regard to familial and other matters. As a result, institutional supports that anchored moral debate about domestic matters began, like the family itself, to recede.

Chief among these institutional supports were the various churches that molded Americans' understandings of family life. De Tocqueville, the most trenchant observer of nineteenth-century American life, observed:

[American priests] are at pains to keep out of affairs and not mix in the combinations of parties. One cannot therefore say that in the United States religion influences the laws or political opinions in detail, but it does direct mores, and by regulating domestic life it helps to regulate the state.

1 do not doubt for an instant that the great severity of mores which one notices in the United States has its primary origin in beliefs. ... [Religion] reigns supreme in the souls of the women, and it is women who shape mores. Certainly of all countries in the world America is the one in which the marriage tie is most respected and where the highest and truest conception of conjugal happiness has been conceived. ${ }^{60}$

57. See, e.g., Bellotti v. Baird (Bellotti II), 443 U.S. 622, 634-35 (1979) (describing children as vulnerable and dependent on adult authority and direction); Zelizer, supra note 13, at 3-7 (describing nineteenth-century development of notion of children as precious "objects of sentiment").

58. See Whitehead, supra note 4, at 153-81 (exploring tension between newfound parental autonomy and children's need for stability).

59. Comparing and choosing between two such models (a nuclear model of family and an extended-kin model of family) played a central role in the Supreme Court's plurality opinion in Troxel v. Granville. See 530 U.S. 57, 63-67 (2000) (plurality opinion); see also infra Part V (describing these models of family and the Court's treatment of them in Troxel).

60. Alexis de Tocqueville, Democracy In America 268 (J.P. Mayer \& Max Lerner eds., George Lawrence trans., 1966) (1830) [hereinafter Lawrence's de Tocqueville]. 
By the second half of the twentieth century, the influence of churches had clearly begun to wither. Church attendance declined, and even those who continued to participate in religious life became "less committed to a particular community of believers" than had been the case a generation or two earlier. ${ }^{61}$ Wade Clark Roof and William McKinney describe Americans' religious participation during these years:

[L]arge numbers of young, well-educated, middle-class youth ... defected from the churches in the late sixties and the seventies. ... [S] ome joined new religious movements, others sought personal enlightenment through various spiritual therapies and disciplines, but most simply "dropped out" of organized religion altogether. ${ }^{62}$

Interest in schools, another social institution with the critically important power to influence domestic matters, has declined similarly. Not only has American education lost much of its raison d'être, ${ }^{63}$ but schools have largely lost the ability, so important to the nation in the nineteenth and early twentieth centuries, to define and inculcate moral values. ${ }^{64}$ That decline is suggested, among other things, by a dramatic loss of interest in parent-teacher associations, beginning in the last decades of the twentieth century. ${ }^{65}$ This shift is particularly important in that it appears to signal a loss of parental interest in the schooling of their children, perhaps even a sign of a loss of interest in schools generally. ${ }^{66}$ Decreasing national interest in public education in particular is starkly indicated by governmental failure to adequately support schools as compared with other nations or with this nation two decades ago. ${ }^{67}$ In concluding his 1997 book The End of Education, Neil Postman wrote:

61. Putnam, supra note 27 , at 74 .

62. Wade Clark Roof \& William McKinney, American Mainline Religion 17-18 (1987), quoted in Putnam, supra note 27, at 73. Roof and McKinney also discuss the fact that the "changing face of religion in America" involved a number of different aspects, including "demographic, cultural, [and] psychological." Id. at 7-8. All of these factors led to increased religious individualism and less conformity during this period. Id. at 32-33.

63. See Postman, Childhood, supra note 53, at 140, 150-52. Postman suggests that educators no longer know what they want to teach or are supposed to teach. He writes, "[A] knowledge of history, literature, and art, which once was tbe mark of an educated adult, recedes in importance." Id. at 140.

64. See Postman, Education, supra note 37, at 13-14 (describing the vision of schools at tbis country's founding as one that assumed that the educator's task included teaching children about "The American Creed," and about the centrality of liberty in American life).

65. Putnam, supra note 27 , at 55-57. Putnam reports a "shocking" decline in tbe number of parents who joined PTAs, beginning in 1960. Id. He reports: "On average, every year throughout the quarter century after 1960 another 1.2 percent of all American families with kids-more than 250,000 families a year-dropped out of the PTA." Id. at 56.

66. Id. at 55-57.

67. See, e.g., Coontz, Really Are, supra note 26, at 143 (noting that spending on schools "has not kept up with needs for the past twenty years," and that "[i]nternational 
[T] here is more talk than ever about schools' being nineteenthcentury inventions that have outlived their usefulness. Schools are expensive; they don't do what we expect of them; their functions can be served by twenty-first-century technology. Anyone who wants to give a speech on this subject will draw an audience, and an attentive one. An even bigger audience can be found for a talk on [a] second point: that the idea of a "public school" is irrelevant in the absence of the idea of a public; that is, Americans are now so different from each other, have so many diverse points of view, and such special group grievances that there can be no common vision or unifying principles. ${ }^{68}$

The educational significance of this decline in national interest in schools is indicated by the many studies that show that the success of schools correlates decisively with community (especially parental) involvement. ${ }^{69}$

Paralleling the institutional decline of schools and churches, a wide set of voluntary community organizations regarded by Alexis de Tocqueville as central to the sustenance of the American moral order ${ }^{70}$ have dwindling memberships. Americans still create organizations and maintain those already created, but David Horton Smith discovered that only about half of the groups listed in the 1988 Encyclopedia of Associations have any individual members. ${ }^{71}$ Most of these organizations have little or no "grassroots participation," and some of those with apparently burgeoning memberships, such as the American Association of Retired Persons, demand no expenditure of time or effort beyond signing a check annually. ${ }^{72}$ Robert Putnam concluded at the turn of the twenty-first century that for three decades Americans' "active involvement in face-to-face organizations ... plummeted, whether we consider organizational records, survey reports, time diaries, or consumer expenditures." ${ }^{33}$ Similarly, membership in professional organizations such as the American Bar Association and the American Medical Association declined absolutely even though the number of people in these professions mushroomed. ${ }^{74}$ The erosion of community organizations facilitated growing disenchantment,

comparisons reveal that education is simply not a national priority in the United States the way it is in many countries").

68. Postman, Education, supra note 37, at 195-96. Postman, though clearly concerned that these predictions may be well founded, nevertheless chooses-almost as an act of faith-to predict that schools, and public schools in particular, will endure. Id. at I97.

69. Putnam, supra note 27 , at $302-03$.

70. Lawrence's de Tocqueville, supra note 60 , at $485-88$.

71. David Horton Smith, National Nonprofit, Voluntary Associations: Some Parameters, 21 Nonprofit \& Voluntary Sector Q. 81, 88 (1992), cited in Putnam, supra note 27 , at 450 n.5.

72. Putnam, supra note 27 , at $49-51$.

73. Id. at 63 .

74 . Id. at 85 . 
especially among young adults, with religion, patriotism, and traditional family forms and values (such as marriage).$^{75}$

Thus, all in all, Americans, increasingly beset with practical and theoretical questions about the scope and meaning of family and of kin relationships, are increasingly bereft of institutional settings to which they might turn for assistance. The weakening authority and bent of church and school leaders to direct public responses to the shifting forms of family life, and the general dissolution of voluntary associations of all types, have pushed Americans to seek an alternative arbiter of domestic matters. They thus have turned to the law, not only to settle particular familial disputes, but, more generally, to arbitrate the widespread debate about family. ${ }^{76}$ Moreover, in imploring the law to decipher the shifting forms that define the domestic sphere, Americans have turned to the federal courts, asking them to apply constitutional law to establish the legitimate parameters of contemporary family life.

\section{Changes in Family Law: A Response to Changes in Society}

Of the institutions that directed the development of nineteenth-and early-twentieth-century families, most were of help only to small pockets of the American population by the end of the twentieth century. As a result, more and more people have asked the law to establish broad policies about the scope and meaning of family relationships-to direct the evolving parameters of the domestic sphere. ${ }^{77}$ But traditionally, family law served-and continues to serve-largely to reflect, rather than to construct, family mores. As the family lost its moorings in nineteenth-century notions of domestic life, even the comparatively flexible family law system that developed to serve the interests of the Industrial Revolution proved a poor substitute for the institutional moral arbiters of an earlier age.

Until the second half of the twentieth century, the legal system relied almost exclusively on principles of state law to resolve domestic disputes. ${ }^{78}$ The contradictions underlying the effort of state courts to sus-

75. Schulman, supra note 27 , at 11,16 (describing increasing popularity of counterculture in U.S. during 1970s).

76. See Rubin, supra note 1, at 183-99 (summarizing contemporary role of Supreme Court in making family policy).

77. See, e.g., id. at 11 (noting that "[i]n recent years the Supreme Court of the United States has been inundated with social and family issues").

78. The U.S. Supreme Court has long restricted federal courts from granting divorces, awarding alimony, or deciding the custody of children in the context of parental divorce. See, e.g., In re Burrus, 136 U.S. 586, 594, 597 (1890) ("As to the right to the control and possession of this child, . . it is one in regard to which neither the Congress of the United States nor any authority of the United States has any special jurisdiction."); Barber v. Barber, 62 U.S. (21 How.) 582, 584 (1858) ("We disclaim altogether any jurisdiction in the courts of the United States upon the subject of divorce, or for the allowance of alimony, either as an original proceeding in chancery or as an incident to divorce a vinculo, or to one from bed and board."); Homer H. Clark, Jr., The Law of Domestic Relations in the United States 414-20 (2d ed. 1987) (considering federal 
tain traditional understandings of childhood, ${ }^{79}$ while providing for a very different understanding of adults within families, have widened and become increasingly transparent. At the same time, family litigants, lawyers, and courts seek methods of resolving domestic disputes other than those traditionally provided by state-based family law. Thus, among other things, ${ }^{80}$ family disputants have increasingly turned to constitutional principles to resolve questions about the meaning and scope of domestic relationships.

This Part reviews the development of family law as a separate sphere of legal regulation soon after the founding of the American Republic, and suggests that the bedrock assumptions undergirding American family law have begun to erode. Additionally, this Part discusses the early development of mechanisms within family law-such as the "best interest" standard-that accommodated social change while appearing to safeguard stability and value tradition. It then considers contemporary state lawmakers' difficult struggle to mediate among alternative visions of family, and suggests that mechanisms constructed in the nineteenth century to resolve family disputes have begun to fail as contradictory understandings of family life proliferate. Finally, this Part examines the increasing resort by both state and federal courts to constitutional principles as they try to construct a new framework within which to understand and regulate family relationships.

\section{A. State Law Defined the "Traditional" Family}

Family law emerged as an identifiable and separate area of law in the decades surrounding the turn of the nineteenth century. ${ }^{81}$ During most of its history, American family law responded to and reinforced evolving cultural patterns. ${ }^{82}$ For the most part, family law did not initiate shifts in

jurisdiction in domestic relations cases). Moreover, federal courts generally "stayed out of family law" more broadly until the last half of the twentieth century. Rubin, supra note 1, at 12-15 (describing changes that presaged increasing involvement of federal courts in family matters by last decades of twentieth century). A crucial shift in this pattern occurred in 1974 when Congress provided for federal financial and procedural help to states in enforcing child support claims. Clark, supra, at 262.

79. See supra note 17 and accompanying text (describing David M. Schneider's ethnographic account of American families at mid-twentieth century).

80. Alternative Dispute Resolution (including arbitration, mediation, and negotiated settlements) provides another comparatively recent alternative for resolving family disputes within legal settings. California, for instance, has mandated mediation in custody and visitation disputes since 1981. Harris \& Teitelbaum, supra note 31, at 420 . Since then, other states have followed California's model and either require or encourage mediation before litigants can be heard in court. Id. See generally Trina Grillo, The Mediation Alternative: Process Dangers for Women, 100 Yale L.J. 1545, 1551 n.14, 1551-55 (1991) (tracing rise of mandatory custody mediation in California and noting its spread to other states).

81. Grossberg, supra note 11 , at 3-4.

82. Ira Mark Ellman et al., Family Law: Cases, Text, Problems 5 (3d ed. 1998) (noting "family law traditionally reflected core cultural norms"). 
understandings of family life. But, until recently, it often proved able to respond quickly and ingeniously to shifting understandings of family within the wider society, and thus to establish guideposts and limits that directed and channeled the transformation of American family life. ${ }^{83}$

The creation of the so-called "best interest" standard illustrates the ability of nineteenth- and twentieth-century family law to solidify, though generally not to design, social mores. The standard has been applied to resolve disputes about children's custody and living arrangements, and sometimes even about their parentage. ${ }^{84}$ Development of the best interest standard in the early nineteenth century followed a long period of common law rule which almost always gave custody of children to fathers in contested cases. ${ }^{85}$ The standard, which encourages courts to focus on children's welfare in rendering custody decisions, has been widely criticized as vague and nondirective. ${ }^{86}$ Yet it has flourished, directing courts

Family law is not always progressive, however. In the late nineteenth century, family law provided a rigid institutional opposition to shifts in traditional forms of family. In particular, abortion was first defined by state law as an offense in the 1820s. Grossberg, supra note 11, at 161. And in the last decades of the nineteenth century, tolerance of "informal matrimony" was opposed by lawmakers and others who instituted reforms that provided for greater state intervention in marriage. 1d. at 83 .

For the most part, family law continues to respond to evolving social patterns. For example, Mary Ann Glendon notes that " $[\mathrm{m}]$ uch of family law is no more-and no less-than the symbolic expression of certain cultural ideals," and that " $[t]$ oday, modernized versions of [codes about spousal behavior] tell husbands and wives that they are equal partners in running a household." Mary Ann Glendon, Abortion and Divorce in Western Law 10 (1987). However, as those patterns increasingly diverge from patterns established in the early decades of the Industrial Revolution, family law is less and less able to respond consistently to emerging disputes. See Ellman et al., supra, at 6 (noting that family law is "placed under great stress when the culture is itself under pressure or in transition," and then noting decline in families reflecting traditional family values and changing visions of gender roles in contemporary society).

83. See Grossberg, supra note 11 , at 12 (describing law's response to shift in postRevolutionary America from a "relatively stable, homogeneous agrarian society" to a "bustling, bourgeois nineteenth-century nation").

84. In a set of recent cases occasioned by reproductive technology, courts have premised decisions about parentage on "parental intent," and have then justified that approach by concluding that "the interests of children, particularly at the outset of their lives, are '[un]likely to run contrary to those of adults who choose to bring them into being." Johnson v. Calvert, 851 P.2d 776, 783 (Cal. 1993) (alteration in original) (quoting Marjorie M. Shultz, Reproductive Technology and Intent-Based Parenthood: An Opportunity for Gender Neutrality, 1990 Wis. L. Rev. 297, 397).

85. Rex v. Manneville, 102 Eng. Rep. 1054 (K.B. 1804), is frequently cited to show the strength of the common law rule even at the start of the nineteenth century. The court in Manneville granted custody of an infant to the father despite the mother's uncontested testimony about the father's great cruelty. Id. at 1054-55.

86. Robert Mnookin's I975 critique of the best interest standard has provided inspiration for many others who have criticized the standard. See Robert H. Mnookin, Child-Custody Adjudication: Judicial Functions in the Face of Indeterminacy, Law \& Contemp. Probs., Summer 1975, at 226, 249-62; see also Jon Elster, Solomonic Judgments: Against the Best Interest of the Child, 54 U. Chi. L. Rev. 1, 1I-16 (1987) (arguing that the principle that the "best interest of the child ought to be the sole, main, or first and 
to a developing set of social presumptions for settling disputes among adults about children's custody and lives.

The standard's indeterminacy, while broadly criticized, has allowed courts to accommodate the changing shape of the domestic arena while ostensibly adhering with remarkable steadfastness to one widely accepted rule. ${ }^{87}$ Concerned with the resolution of specific family disputes, the interpretive responses of state courts reflected shifting cultural patterns and beliefs. Over time, the effects of such cultural shifts on the standard's evolution became obvious. For example, applications of the standard initially resulted in custody determinations favoring mothers. ${ }^{88}$ Later, however, courts relied on the standard to effect other presumptions and preferences that variously favored a child's same gender parent, ${ }^{89}$ a "primary caretaker," 90 a "psychological parent, ${ }^{91}$ and joint parental custody. ${ }^{92}$ In effect, the standard allowed local judges to focus on family disputants' concrete problems through reference to local mores and beliefs. Further, by providing a legal anchor, it helped judges anxious to bypass the abstract philosophical and jurisprudential quandaries that undergirded disputants' specific family dilemmas. For about two centuries, the ap-

paramount consideration in custody decisions" is indeterminate); Martha L. Fineman \& Anne Opie, The Uses of Social Science Data in Legal Policymaking: Custody Determinations at Divorce, 1987 Wis. L. Rev. 107, 118-24 (discussing the difficulty in applying the best interest standard).

87. In part, the best interest standard has survived because it has presumed a central concern with children and their welfare during two centuries that venerated childhood and espoused-even if far more often in theory than in fact-the protection of particular children. In short, the standard has reflected an ideology that defined childhood as sacred and that envisioned family life as serving children's welfare. As a result, the best interest standard represented the preservation of a moral order. See Janet L, Dolgin, Why Has the Best-Interest Standard Survived?: The Historic and Social Context, 16 Child. Legal Rts. J. 2, 6-8 (1996).

88. Courts in the United States first focused on the interests of children in custody disputes in the early nineteenth century. These cases began to reverse a long-standing preference for fathers in custody disputes. See Lewis Hochheimer, The Law in Its Relation to the Child, 67 Cent. L.J. 395, 395-96 (1908). In 1840, a New York court granted custody of a young child to a divorcing mother on the ground that " $t]$ he interest of the infant is deemed paramount to the claims of both parents." Mercein v. People ex rel. Barry, 25 Wend. 64, 102 (N.Y. 1840). For a description of the assumptions about children's best interests that developed in the nineteenth century, see Jamil S. Zainaldin, The Emergence of a Modern American Family Law: Child Custody, Adoption, and the Courts, 1796-1851, $73 \mathrm{Nw}$. U. L. Rev. 1038, 1072-74 (1979) (delineating assumptions about children's best interests that developed in nineteenth century).

89. See, e.g., Warner v. Warner, 534 N.E.2d, 752, 754 (Ind. Ct. App. 1989) (relying in part on psychologist's report that paternal custody served best interests of male child); In re Marriage of Clement, 627 P.2d 1263, 1265 (Or. Ct. App. 1981) (stressing significance of female role model in granting maternal custody of female child).

90. See, e.g., Garska v. McCoy, 278 S.E.2d 357, 360-61 (W. Va. 1981) (applying primary caretaker presumption to establish custody for young child).

91. See, e.g., Bennett v. Jeffreys, 356 N.E.2d 277, 283-85 (N.Y. 1976) (granting custody to child's psychological parent despite availability of "fit" mother).

92. See, e.g., Taylor v. Taylor, 508 A.2d 964, 966-68 (Md. 1986) (listing factors relevant to grant of joint custody). 
proach allowed state judges to construct pliable rules, responding to the evolving concerns of the domestic arena. Those rules and their application successfully displaced the need for philosophical inquiry and thus served a society with a broad penchant for solving practical problems without engaging in extended theorizing. ${ }^{93}$

Consistently, however, throughout the two centuries of family law's reliance on the standard, one central belief remained essentially inviolable: protecting children is essential to the survival of the family and thus ultimately to the survival of society. ${ }^{94}$ That presumption in turn depended on an understanding of children as vulnerable, innocent, and special. ${ }^{95}$ In short, the best interest standard, though indeterminate and

93. Alexis de Tocqueville commented on this penchant in the nineteenth century, and contrasted it with a more long lasting commitment in Europe to philosophical speculation:

Less attention, I suppose, is paid to philosophy in the United States than in any other country of the civilized world. The Americans have no school of philosophy peculiar to theinselves, and they pay very little attention to the rival European schools. ... .

Seeing that they are successful in resolving unaided all the little difficulties they encounter in practical affairs, [Americans] are easily led to the conclusion that everything in the world can be explained and that nothing passes beyond the limits of intelligence.

Lawrence's de Tocqueville, supra note 60, at 393-94.

94. Children were not always understood as essential to family life. Indeed the notion of a stage of life separating infancy (until about age seven) from adulthood only began to develop in the early modern period of Western history. See Philippe Aries, Centuries of Childhood: A Social History of Family Life I5-25 (Robert Baldick trans., Vintage Books 1962) (1960) (dating the development of the notion of childhood to the sixteenth and seventeenth centuries). Development of the notion of childhood was essential to the understanding of families that developed in the nineteenth century as moral units dedicated to the care and protection of innocent children. Id. at 4I I-I5 (stating that postfeudal conception of childhood allowed society to view families as having a "moral and spiritual function" at their core).

In the colonial period, children "seem to have been loved" by their parents, but they were not appreciated as "unique individuals." Coontz, Social Origins, supra note I I, at 87.

95. Many children came to the United States as indentured servants, and until the middle of the nineteenth century, children were often hired out as indentured servants within the United States. See Grossberg, supra note 11, at 259-68; Mason, supra note 14, at 1-2. During the nineteenth century, the elaboration of the best interest standard reflected the development of a new, romanticized view of women and children.

At first, the best interest standard served to justify judicial orders that preferred mothers to fathers in custody disputes. Grossberg, supra note 11, at 237-38 (explaining that concern with importance of nurturing young children displaced " $[t]$ raditional male authority"). Social understandings of mothers as inherently nurturing and protective developed simultaneously with shifts in understandings of children from "object[s] of utility" to "object[s] of sentiment." Zelizer, supra note 13, at 7. Zelizer notes that in nineteenth-century America, "[a]s instrumental ties weakened [within families], the emotional value of all family members--including children-gained new saliency." Id. at 8-9 (footnote omitted). Zelizer further remarks that " $t \mathrm{t}]$ he increasing domestication of middle-class women in the nineteenth century. . . "went hand in hand with the new conception of children as precious." Id. at 9 (quoting Carl N. Degler, At Odds: Women and the Family in America from the Revolution to the Present 73-74 (I980)). 
flexible, consistently presumed that children are defined through their status and are not autonomous individuals to whom rights should be assigned by the law. Should this presumption and the beliefs that surround it be undermined - as may now be happening - the best interest standard and the rule of family law it has served will likely be rendered marginal or perhaps even discarded.

The approach to solving family disputes by reference to shared societal values, as represented by the best interest standard, began to falter visibly in the last decades of the twentieth century as the broad agreement about family that had characterized the nineteenth and early twentieth centuries began to fade among many groups in society. ${ }^{96}$ Consequently, a set of legal rules that regulated American family life for almost two centuries-along with the local courts that had crafted and applied themalso began to waver in confusion and uncertainty. ${ }^{97}$ Lawmakers, reflecting society more broadly, seem overwhelmed by contradictory images of family, each of which is rendered reasonable with a shift in perspective. ${ }^{98}$

The confusion resulting from this societal sea change has become apparent as state courts have constructed a series of tentative responses to conflicting images of adults and of children within families. Some courts have presumed that adults' familial choices need not entail consequences for children. For instance, courts attempting to discern legal parentage in cases of gestational surrogacy have relied on parental intent as the ground on which to identify a child's "real" parents. ${ }^{99}$ Other courts have presumed that traditional forms and structures-and thus traditional understandings of family-can be safeguarded, even as those forms and structures serve unfamiliar ends. For instance, a number of state court decisions involving custody and visitation cases involving nonmarital and nonbiological parents are illustrative. In E.N.O. v. L.M.M., the lesbian lover of a child's biological mother sought visitation with the child to whom she had related as a second mother. ${ }^{100}$ The Massachusetts court "acknowledge[d] that the 'best interests' standard is somewhat amor-

96. See supra Part 11.A (describing move toward veneration of individualism within domestic settings in late twentieth century).

97. See supra notes 47-50 and accompanying text (describing how in the late 1960s the law began to provide for no-fault divorce, prenuptial agreements, the paternity of unmarried fathers, and a constitutional right to make reproductive decisions).

98. See infra Part V (discussing the appearance of multiple images of the family in the Court's plurality opinion in Troxel v. Granville, 530 U.S. 57 (2000)); infra Part VI (analyzing the consequences of such contradictory images in the Troxel Court's plurality opinion).

99. These courts have then presumed that replacing biology with intention as the ground on which parentage is established need not have important consequences for the children involved. See, e.g., Johnson v. Calvert, 851 P.2d 776, 782-83 (Cal. 1993) (affirming that because the genetic mother intended to raise the child as her own, she was the natural mother of a child gestated by another); see also Dolgin, Defining the Family, supra note 46, at 126-33, 185-94 (analyzing decisions of California courts in Johnson).

100. 711 N.E.2d 886, 889 (Mass. 1999). 
phous."101 The court concluded that the welfare of the child was best served by ensuring a continuing relationship between the child and the nonbiological ("de facto") mother. ${ }^{102}$ The court thus recognized a family that reflected adults' nontraditional familial choices and that presumptively remained "traditional" in protecting a child's welfare. ${ }^{103}$ And, finally, in other cases, lawmakers, unable to preserve traditional understandings of children, have viewed at least certain children as autonomous individuals. Lawmakers have recognized children's individuality in cases involving children in seriously dysfunctional families ${ }^{104}$ and in cases that involved children accused of offenses that would be crimes if committed by an adult. ${ }^{105}$

The contradictions and confusions underlying these responses have been especially significant because state courts, applying state laws to questions of family law, had provided one of the few remaining institutional voices widely willing and able to presume a moral order and to effect it within domestic settings. As the questions posed by family litigants increasingly began to surprise, and often to overwhelm, a legal system established to safeguard the traditional family-which was constructed to serve the goals of the Industrial Revolution-litigants and lawmakers have been encouraged to seek alternative modes of responding to domestic disputes. ${ }^{106}$ These new modes seem less antithetical to the recognition of autonomous individuality within familial settings than do traditional legal responses to family matters. ${ }^{107}$

101. Id. at 890 .

102. 1d. at 893 .

103. See also infra Part VI.B (considering de facto parentage cases decided after Troxel).

104. See, e.g., In re the Appeal in Pima County Juvenile Severance Action No. S113432, 872 P.2d 1240, 1246 (Ariz. Ct. App. 1993) (granting four children right to petition in their own right for termination of their father's paternity); Gregory K. v. Ralph K., No. CI92-5127, 1992 WL 551488, at*1 (Fla. Cir. Ct. July 20, 1992) (granting young boy standing to petition in own right for termination of mother's legal maternity). Although Cregory $K$. was reversed on appeal, Kingsley v. Kingsley, 623 So. 2d 780, 783 (Fla. Dist. Ct. App. 1993), the trial court decision was widely publicized and discussed and was even pictured in two made-for-television movies. Andrew L. Shapiro, Children in Court-The New Crusade, Nation, Sept. 27, 1993, at 301, 301.

105. More and more, states are treating such juvenile offenders as adult criminals. See, e.g., Richard E. Redding, Juveniles Transferred to Criminal Court: Legal Reform Proposals Based on Social Science Research, 1997 Utah L. Rev. 709, 713-16.

106. See infra notes 113-123 and accompanying text (describing law's increasing readiness to define family members as autonomous individuals and to grant them the right to enter into contracts that define the terms of their familial relationships); see also supra note 80 and accompanying text (noting reliance of American legal system both on constitutional principles and on alternative dispute resolution in responding to family disputes).

107. See, e.g., Janet L. Dolgin, The Family in Transition: From Griswold to Eisenstadt and Beyond, 82 Geo. L.J. 1519, 1553-55 (1994) [hereinafter Dolgin, The Family] (analyzing Eisenstadt v. Baird, 405 U.S. 438 (1972), as an unprecedented recognition of adults within families as autonomous individuals). 


\section{B. Constitutional Principles Redefine the Family}

Prodded by litigants seeking respite from state family law's growing inability to decide their disputes satisfactorily, courts have turned to constitutional jurisprudence (and the rights it extends to individuals treated unequally and unfairly) for help in understanding and resolving disputes within, and about, families. Just as their search for resolution of questions of the family led them to embrace a different body of law, litigants have also begun to press their claims in a different system of tribunals. With constitutional rights suddenly at stake, domestic litigants found a modus operandi for seeking resolutions in federal court. 108

This strategic shift was encouraged by a search for answers to new questions about family relationships, and was facilitated by a related and broader shift in constitutional law more generally that also occurred in the second half of the twentieth century. In this period, the Supreme Court acknowledged and advanced new understandings of personhood through the development of a constitutional jurisprudence of individual rights premised largely on the Fourteenth Amendment, though sometimes on other amendments, including the First. ${ }^{109}$ This jurisprudence,

108. A federal cause of action was critical to domestic litigants seeking access to federal courts, as diversity jurisdiction is unavailable in domestic cases. Ankenbrandt v. Richards, 504 U.S. 689, 698-99 (1992). Thus, because of the "domestic relations exception" to diversity jurisdiction, family disputants can be heard in federal court only when a federal statute or a federal constitutional question is at stake. Originally, the domestic relations exception to diversity jurisdiction was justified through reference to dicta in Barber v. Barber, 62 U.S. (21 How.) 582, 584 (1859) ("We disclaim altogether any jurisdiction in the courts of the United States upon the subject of divorce, or for the allowance of alimony, either as an original proceeding in chancery or as an incident to divorce $a$ vinculo, or to one from bed and board."). Nonetheless, in 1992 the Court found the exception to be grounded in the Judiciary Act of 1789. Ankenbrandt, 504 U.S. at 698-99; see also Ellman et al., supra note 82, at 794-95 (considering domestic relations exception to diversity jurisdiction).

Litigants have been quick to avail themselves of the open federal forum. See Rubin, supra note 1, at 11-13 (noting that " $[i] n$ recent years the Supreme Court of the United States has been inundated with social and family issues" and that "[u]ntil recently federal courts have stayed largely out of family law"). A recent issue of Family Advocate, a journal of the ABA Family Law Section, is devoted to examining "The Federalization of Family Law." Family Advocate, Spring 2001. An article in the issue lists fifty-three U.S. Supreme Court cases involving family matters. Laura W. Morgan, Supreme Court Cases, Family Advocate, Spring 2001, at 15, 15-17. The earliest case on the list, Reynolds $v$. United States, declared constitutional a state law prohibiting bigamy that was challenged on First Amendment grounds by a Mormon. 98 U.S. 145, 168 (1878), cited in Morgan, supra, at 17.

109. In Griswold v. Connecticut, Justice Douglas located a "right to privacy" in a host of constitutional amendments, writing:

By Pierce $v$. Society of Sisters, the right to educate one's children as one chooses is made applicable to the States by the force of the First and Fourteenth Amendments. ...

... Various guarantees create zones of privacy. The right of association contained in the penumbra of the First Amendment is one. . . The Third Amendment in its prohibition against the quartering of soldiers "in any house" in 
developed apart from any express concern with domestic questions, aimed primarily to protect individuals' personhood regardless of historic categorizations based on status (including categorizations reflecting differences in race, national origin, and gender). ${ }^{110}$ The first, and probably still most important, case reflecting this new trend was Brown v. Board of Education. ${ }^{111}$

Thus, two socio-legal shifts-one entailing the transformation of American families and the other entailing the elaboration of a constitutional jurisprudence of personhood-encouraged the examination of domestic disputes through constitutional principles. These changes coalesced in two sets of Supreme Court decisions, each predicated on a different understanding of "family." The first set primarily involved adults' familial decisions. For the most part, these cases sketch a set of constitutional protections for reproductive choices by adults, including choices about contraception and abortion. ${ }^{112}$ Although the jurisprudential ground on which these cases rest has been vociferously debated, ${ }^{113}$ the cases as a group reflect a coherent social theme. That theme repre-

time of peace without the consent of the owner is another facet of that privacy. The Fourth Amendment explicitly affirms the "right of the people to be secure in their persons, houses, papers, and effects, against unreasonable searches and seizures." The Fifth Amendment in its Self-Incrimination Clause enables the citizen to create a zone of privacy which government may not force him to surrender to his detriment. The Ninth Amendment provides: "The enumeration in the Constitution, of certain rights, shall not be construed to deny or disparage others retained by the people."

381 U.S. $479,482-84$ (1965).

110. See, e.g., Gerald Gunther \& Kathleen M. Sullivan, Constitutional Law 662-749 (13th ed. 1997) (describing constitutional jurisprudence of "suspect classifications," including those based on race, gender, alienage, and sexual orientation).

111. 347 U.S. 483 (1954). Brown was clearly more deeply rooted in the text of the Constitution than later cases delineating rights within domestic contexts, but Brown encouraged the subsequent development of Fourteenth Amendinent rights that undermined social inequalities based on race, gender, and marital status, among other things. See, e.g., Trimble v. Gordon, 430 U.S. 762, 776 (1977) (invalidating 1llinois law precluding illegitimate children from inheriting from their fathers by intestate succession); Loving v. Virginia, 388 U.S. 1, 12 (1967) (invalidating Virginia statute prohibiting interracial marriage).

112. See, e.g., Roe v. Wade, 410 U.S. 113, 164-66 (1973) (extending limited constitutional right to abortion); Eisenstadt v. Baird, 405 U.S. 438, 454-55 (1972) (invalidating state prohibition on the distribution of contraceptives to unmarried individuals); Gristuold, 381 U.S. at 485-86 (invalidating state prohibition on the distribution of contraceptives to married individuals).

113. The debate about the jurisprudence underlying these cases poses the interpretivists against the noninterpretivists. The first group argues that the cases as a set are misguided because nothing in the Constitution's text supports a right to privacy, to familial autonomy, or to marriage. The noninterpretivists, in contrast, argue that constitutional jurisprudence should not be limited by the document's explicit text. See, e.g., Developments in the Law: The Constitution and the Family, 93 Harv. L. Rev. 1156, 1169 (1980) [hereinafter The Constitution and the Family]. John Hart Ely provides additional definitions: Interpretivist review is limited to safeguarding "norms that are stated or clearly implicit in the written Constitution," whereas noninterpretivist review 
sents the position, now widely reflected in state laws regulating adults in families, that an adult's autonomous individuality does not cease to exist at the family hearth. Indeed, this theme represents the notion that adults should be free to construct their own domestic relationships within a fairly wide range of options, including the options of nonmarital cohabitation, divorce without accusations of fault, and reproductive planning. ${ }^{114}$

For instance, cases such as Griswold, ${ }^{115}$ and even more so Eisenstadt, ${ }^{116}$ unequivocally supported the rights of family members (in Griswold as family members and in Eisenstadt as separate individuals) ${ }^{117}$ to make intimate familial choices without state interference. Those decisions and others that followed altered the shape of domestic jurisprudence by ensuring the right of adults to design and negotiate the terms of their family relationships. ${ }^{118}$ These cases were controversial when they

safeguards "norms that cannot be discovered within the four corners" of the Constitution. John Hart Ely, Democracy and Distrust 1 (1980) [hereinafter Ely, Democracy].

114. See supra Part II.A (describing shifts in the family law concerning adults in families that occurred in the second half of the twentieth century).

At least initially, virtually all of the Court's substantive due process responses to domestic issues were widely disputed as a jurisprudential matter. See, e.g., The Constitution and the Family, supra note 113, at 1168-69 (describing debate between interpretivists and noninterpretivists over substantive due process). However, there was far less opposition to the practical consequences of these decisions. The exception is the Court's abortion jurisprudence. The difference is evident in the quantity of contemporary legal scholarship that focuses on the contraception cases (Griswold and Eisenstadt) as compared with the much greater quantity of legal scholarship that focuses on cases involving the right to abortion. For instance, Erwin Chemerinsky's 2001 treatise on constitutional law devotes about eight pages to constitutional decisions involving contraception, Erwin Chemerinsky, Constitutional Law 730-38 (2001), and about fortyseven pages to constitutional decisions involving abortion, id. at 738-85. The opposition to the Court's abortion decisions (the so-called right-to-life movement) is largely grounded, at least ostensibly, on the notion of the fetus's personhood as well as on the right, vel non, of individual women to make choices about their intimate relationships. See, e.g., John T. Noonan, Jr., The Root and Branch of Roe v. Wade, 63 Neb. L. Rev. 668, 673 (1984) (arguing that the Roe Court incorrectly viewed the fetus as "pure potentiality or a mere theory before viability"). This movement stems from a set of churches (including, chiefly, the Catholic Church) that represent the vestiges of a world that once widely valued relationships based on notions of status. See, e.g., Dolgin, The Family, supra note 107, at 1526-30 (describing significance of status in medieval, Christian world).

115. 381 U.S. at $485-86$ (invalidating state prohibition on the distribution of contraceptives to married couples).

116. 405 U.S. at 454-55 (invalidating state prohibition on the distribution of contraceptives to unmarried individuals).

117. See Dolgin, The Family, supra note 107, at 1545-56 (analyzing different ideological perspectives in Griswold and in Eisenstadt).

I18. See, e.g., Carey v. Population Servs. Int'l, 43I U.S. 678, 686 (1977) (invalidating state law restricting advertising and the distribution of contraceptives because law infringed on "protected individual choices"); Roe v. Wade, 410 U.S. 113, 164-66 (1973) (extending limited constitutional right to abortion). But see Bowers v. Hardwick, 478 U.S. 186, I89 (1986) (upholding state statute criminalizing sodomy). 
were decided. ${ }^{119}$ However, they reflected a coherent position that was being internalized within society ${ }^{120}$ as the debate about family took shape around the decisions themselves. ${ }^{121}$ But the implications of those decisions for children born to or socialized by adults enjoying (or suffering from) far-reaching domestic choices were not, when the decisions were rendered, completely acknowledged or understood. ${ }^{122}$ In fact, they are

The assumption that individuals retain their personal autonomy within a family was expressly stated in Eisenstadt. See 405 U.S. at 453 (defining "marital couple" as "an association of two individuals each with a separate intellectual and emotional makeup"). It was not express in Griswold. However, commentators widely have read Griswold to protect the behavior of individual adults within intimate settings. See, e.g., Anita L. Allen, Autonomy's Magic Wand: Abortion and Constitutional Interpretation, 72 B.U. L. Rev. 683, 688 (1992) (characterizing Griswold as providing a "broad protection of what is appropriately considered private life"); Phyllis Coleman, Who's Been Sleeping in My Bed? You and Me, and the State Makes Three, 24 Ind. L. Rev. 399, 404 (I99I) (asserting that the Griswold line of cases recognized "an individual's right to intimate associations without interference from the State").

119. The jurisprudential debate centered around the legitimacy vel non of substantive due process review. See generally Ely, Democracy, supra note II3, at I4-2I (discussing doctrine of substantive due process); The Constitution and the Family, supra note II3, at I161-62 (noting that the ultimate basis of protection of "fundamental" rights such as "activities relating to marriage, procreation, contraception, abortion, family relationships, and the rearing and education of children" is the doctrine of substantive due process (citations omitted)). Beyond a basic disagreement between originalists and nonoriginalists lies a series of suggestions for, and debates about, how best to discern fundamental rights. See generally Moore v. City of E. Cleveland, 431 U.S. 494, 503 (1977) (plurality opinion) (asserting that fundamental rights include liberties "deeply rooted in this Nation's history and tradition"); Chemerinsky, supra note 114, at 698-99 (describing debate about fundamental rights); Harry V. Jaffa, Judicial Conscience and Natural Rights, in Harry V. Jaffa et al., Original Intent and the Framers of the Constitution 237, 237-67 (1994) (arguing for focus on "natural law" in discerning fundamental constitutional rights); Harry H. Wellington, Common Law Rules and Constitutional Double Standards: Some Notes on Adjudication, 83 Yale L.J. 221, 284 (1973) (asserting that fundamental rights should be discerned through focus on moral consensus).

120. In the same era that the Court decided Griswold and Eisenstadt, state courts validated prenuptial agreements in contemplation of divorce, see, e.g., Scherer v. Scherer, 292 S.E.2d 662, 666 ( $\mathrm{Ga}$. I982) (relying on contract law to decide whether to enforce prenuptial agreement); courts recognized contracts between nonmarital cohabitants, see, e.g., Marvin v. Marvin, 557 P.2d 106, 114-16 (Cal. 1976) (upholding contract between domestic partners as long as consideration is other than sexual services); and legislatures in every state provided for some type of no-fault divorce, see Freed, supra note 47 , at 421-23 (listing grounds for divorce by state).

121. With regard to understandings of adults within families, even traditionalists, who presume to counteract the effects of modernity, now rely widely on modern tools. For instance, so-called "covenant" marriage illustrates an effort to protect tradition with modern tools. The statutes allow couples contemplating marriage to choose between a "no-fault" marriage and a "covenant" marriage. Those choosing the second are far more limited in their right to divorce than those choosing the first. See, e.g., Ariz. Rev. Stat. $\S \S 25-90 \mathrm{I}-25-906$ (2000); La. Rev. Stat. Ann. $\$ \S 9: 272-9: 275.1$ (West 2000). Covenant marriage statutes aim to preclude or limit divorce (understood as a modern evil), but in doing so they rely on self-conscious choice (thus exemplifying modernity).

122. See, e.g., Dolgin, Defining the Family, supra note 46, at 213-44 (considering consequences of reproductive technology for children born as a result of assisted 
still not: constitutional cases involving children still do not rest on a coherent jurisprudential base. ${ }^{123}$

The second set of cases is quite different. These cases involve children in families and raise questions about the scope of childhood and the character of the parent-child relationship. The Court, reflecting society, has been far more uncertain and confused in these cases than in those involving adults in families discussed above. ${ }^{124}$ In consequence, judicial decisions involving children are especially difficult to interpret and, as a group, fail to reflect a coherent understanding of the essential issues at stake. Sometimes the Court has relied on the centrality of autonomous individuality to contemporary notions of personhood and has protected children's rights just as it protects the rights of adults in comparable situations. ${ }^{125}$ At other times the Court has viewed children as society routinely did a century ago: unequal dependents who require adult protection, not autonomous individuals whose rights to equality, freedom, and privacy the Constitution protects. ${ }^{126}$ And at still other times, as in cases involving the legal paternity of unwed fathers, ${ }^{127}$ or the right of minor girls

reproduction); Whitehead, supra note 4 , at 107-28 (describing consequences of divorce for children).

123. See John O. McGinnis, Reviving Tocqueville's America: The Rehnquist Court's Jurisprudence of Social Discovery, 90 Cal. L. Rev. (forthcoming 2002) (manuscript at 1, on file with the Columbia Law Review) (analyzing jurisprudence of Rehnquist Court). Professor McGinnis's article largely praises the Rehnquist Court's federalism for its revivification of the sort of "mediating institutions" that de Tocqueville viewed as distinctive of American society. 1d. (manuscript at 4). Yet, McGinnis is uncertain that Troxel furthers that broad end. He asserts:

The world of the family has changed since 1787 , and, absent evidence that the

Framers wanted to enshrine the common law baseline, the Constitution should not bar states from establishing another framework, particularly in order to vindicate the rights of other family members for whom the common law may well have worked better in that era.

1d. (manuscript at 75 n.354).

124. The Court has not been completely without hesitation and ambivalence in cases involving adults' familial choices. In particular, decisions implicating the abortion debate have been revisited and reanalyzed. However, the majority of these cases have involved questions about the right of a minor girl to abort a pregnancy. See infra note 128 and accompanying text (describing such cases).

125. See, e.g., Tinker v. Des Moines 1ndep. Cmty. Sch. Dist., 393 U.S. 503, 511-14 (1969) (recognizing First Amendment rights of high school students); In re Gault, 387 U.S. 1, 30-31 (1967) (extending constitutional protection to children in delinquency proceedings); see also infra note 143 (discussing Tinker and Gault).

126. See, e.g., Parham v. J.R., 442 U.S. 584, 620 (1979) (upholding Georgia statute allowing parents to place their children in state mental hospitals).

127. See, e.g., Michael H. v. Gerald D., 491 U.S. 110, 129-30 (1989) (upholding state statute presuming mother's husband to be father of her child and denying biological father right to rebut the presumption); Lehr v. Robertson, 463 U.S. 248, 264-65, 267-68 (1983) (upholding New York statute that required that notice of a child's adoption be given only to certain groups of men, such as men who had enrolled in the state's putative father registry); Caban v. Mohammed, 441 U.S. 380, 394 (1979) (invalidating, on equal protection grounds, statute that allowed adoption of child over objection of unwed father if adoption was deemed to be in child's best interests); Quilloin v. Walcott, 434 U.S. 246, 
to abort pregnancies, ${ }^{128}$ the Court appears self-conscious about its own hesitancy and confusion. With regard to each set of issues, the Court has examined essentially the same issue again and again and consequently has produced a peculiar, involuted jurisprudence, which suggests a Court motivated by some deeply human interest in creating order from chaosby a sense that if only it could examine the issue once more, clarity would emerge. ${ }^{129}$ So far, it has not.

The reason for this opacity is plain: Neither the text of the Constitution nor settled cultural patterns effectively determine the scope of childhood or the parameters of the parent-child relationship. The Constitution itself does not expressly address the issues at stake and thus provides little explicit, substantive help. ${ }^{130}$ And the body politic as a whole is as

254-56 (1978) (upholding state statute depriving unwed father of right to veto adoption of his children); Stanley v. 1llinois, 405 U.S. 645 , 658-59 (1972) (invalidating state statute that deprived unwed father of paternal rights based on presumption that such fathers were unfit parents).

These cases can be interpreted as consistent. In particular, fathers who established relationships with their children that in some way involved the children's mothers as well were protected. Fathers who did not, were not. However, the Court itself seemed never to recognize this theme underlying its unwed father cases. See Janet L. Dolgin, Just a Gene: Judicial Assumptions About Parenthood, 40 UCLA L. Rev. 637, 647-72 (1993).

128. See, e.g., Planned Parenthood v. Casey, 505 U.S. 833, 899-900 (1992) (upholding provision of state statute requiring pregnant girl seeking abortion to obtain "informed consent" of one parent or guardian or seek judicial bypass of parental consent requirement); Hodgson v. Minnesota, 497 U.S. 417, 450-55, 497 (1990) (invalidating state statute's two-parent consent requirement but upholding same requirement with bypass option); Ohio v. Akron Ctr. for Reprod. Health (Akron II), 497 U.S. 502, 515-16 (1990) (upholding state's one-parent notification statute with judicial bypass option requiring girl to establish her maturity by clear and convincing evidence, or, if unable to do so, to show that her best interests would be served by abortion); Hartigan v. Zbaraz, 484 U.S. 171, 172 (1987) (affirming, by an equally divided Court, lower court's validation of twenty-four hour wait before abortion after parental notification in a statute that also provided for judicial bypass option); Akron v. Akron Ctr. for Reprod. Health, Inc. (Akron I), 462 U.S. 416, 439-42 (1983) (invalidating one-parent consent requirement in municipal ordinance), overruled in part by Casey, 505 U.S. at 870; Planned Parenthood Ass'n v. Ashcroft, 462 U.S. 476, 490-93 (1983) (decided on same day as Akron I, but upholding Missouri one-parent consent requirement with judicial bypass option); H.L. v. Matheson, 450 U.S. 398, 405-07 (1981) (upholding state parental notification statute on ground that minor plaintiff did not have standing to challenge statute as being overbroad because she did not allege that she or any member of her class was mature or emancipated); Bellotti v. Baird (Bellotti II), 443 U.S. 622, 651 (1979) (invalidating state statute requiring two-parent consent without adequate judicial bypass option); Bellotti v. Baird (Bellotti I), 428 U.S. 132, 151-52 (1976) (certifying questions about state two-parent consent statute to state's highest court for interpretation); Planned Parenthood v. Danforth, 428 U.S. 52, 74 (1976) (invalidating Missouri's one-parent consent requirement).

129. For a wonderful statement about the human interest in effecting order, see, e.g., George Santayana, Soliloquies on Masks, in Classic Essays in English 314, 315 (Josephine Miles ed., 2d ed. 1961) (" $[\mathrm{A}] \mathrm{rt}$ and happiness lie in pouring and repouring the molten metal of existence through some such tenable mold.").

130. See, e.g., Rubin, supra note 1, at 4 ("Constitutional doctrine does not provide the Court much guidance in handling family cases ....”). 
confused about them as is the Court. ${ }^{131}$ Thus, the Court, reflecting society, proceeds through implication and innuendo. ${ }^{132}$

The Court's reliance on substantive due process in cases involving disputes about children-even in cases such as Troxel $v$. Granville that focus primarily on adults' comparative rights to relate to and control children in families ${ }^{133}$ - has resulted in a set of decisions grounded in virtually no consistent and coherent understanding of the relationships at issue. ${ }^{134}$ Troxel is especially telling because Justice O'Connor's plurality opinion invokes at least three different, often contradictory, models of the parent-child relationship. ${ }^{135}$ Indeed, although the plurality's holding privileges one of these models over the others, ${ }^{136}$ it is unable to explain why it does so.

In cases involving adults within families-especially cases involving adults' reproductive ${ }^{137}$ and marital choices ${ }^{138}$ - the Court has been far more successful in producing a coherent response to family matters, even though its substantive due process approach has provoked debate on jurisprudential grounds. ${ }^{139}$ This is largely the case because society has broadly accepted an understanding of adults as autonomous individuals, even in domestic settings, and thus has increasingly regarded adults as fit objects for the extension of individualist constitutional rights. ${ }^{140}$

131. See, e.g., id. at 12 (describing "family-related cases on the Court's docket" as "provid[ing] a sampling of the social problems generated by major changes taking place in the structure of American life" during period of socio-cultural confusion).

132. See infra Part V (analyzing Court's approach in Troxel v. Granville, 530 U.S. 57 (2000)).

133. See 530 U.S. at $65-66$ (plurality opinion).

134. See supra notes $127-128$ (delineating Supreme Court decisions involving rights of unwed fathers and cases involving rights of female minors to make abortion decisions).

135. See infra Part V.B (considering the models of family underlying Troxel).

136. See infra Part V.B.4 (describing the plurality's preference for one of the models).

137. See supra notes 112-123 and accompanying text (discussing decisions relating to reproductive choice).

138. For example, in Zablocki $v$. Redhail, the Court defined marriage as a fundamental right and, thus invalidated a Wisconsin statute, which (1) required state residents with support obligations to noncustodial children to obtain a court order before marrying, and (2) prohibited such an order from issuing but on proof of the applicant's compliance with the support obligation and proof that the children covered by the support order were not or were not likely to become charges of state. 434 U.S. 374, 375, 377, 383-91 (1978).

139. See, e.g., John Hart Ely, The Wages of Crying Wolf: A Comment on Roe v. Wade, 82 Yale L.J. 920, 935 (1973) (claiming that "[w]hat is frightening about Roe" is the fact that its "super-protected right is not inferable from the language of the Constitution"); Paul G. Kauper, Penumbras, Peripheries, Emanations, Things Fundamental and Things Forgotten: The Criswold Case, 64 Mich. L. Rev. 235, 252 (1965) (noting that the "right to associate" seems "to be implied from the first amendment" but that "it is quite another thing . . . to [transform] a freedom from unreasonable police searches into a fundamental substantive right").

140. The apparent, lingering debate between advocates of "tradition" and advocates of "modernity" about the limits of adults" familial choices is largely illusory insofar as traditionalists have widely relied on choice as a presumptive tool for recreating more 
A similar consensus has not emerged with regard to children. 1n many contexts, the Court-and the legal system more widely-continue to view children as vulnerable and naive. ${ }^{141}$ ln other contexts, lawmakers provide that children may be granted rights generally accorded to adults if the children involved can prove their maturity. ${ }^{142}$ In still other contexts, lawmakers have redefined large groups of children for various legal purposes as entitled to rights granted adults in similar situations. ${ }^{143}$

traditional forms of family. Covenant marriage statutes are a good example. See supra note 121 (describing these statutes).

141. See, e.g., Bellotti v. Baird (Bellotti II), 443 U.S. 622, 635 (1979) (describing children as vulnerable, lacking in "experience, perspective, and judgment" and in need of parental guidance).

142. See, e.g., id. at 643-44 (requiring female minor seeking abortion without parental involvement to convince court that she is mature enough to choose abortion option or, if not able to prove adequate maturity, to prove that abortion is in her best interest).

143. Lawmakers have viewed children as legally indistinguishable from adults in cases involving First Amendment claims. See, e.g., Tinker v. Des Moines lndep. Cmty. Sch. Dist., 393 U.S. 503, 506-07, 511 (1969) (relying on First Amendment to protect right of students and teachers to enjoin regulation barring wearing of arm bands and noting that students "may not be confined to the expression of those sentiments that are officially approved" because "[i]n the absence of a specific showing of constitutionally valid reasons to regulate their speech, students are entitled to freedom of expression of their views"). But see Vernonia Sch. Dist. 47J v. Acton, 515 U.S. 646, 664-66 (1995) (rejecting Fourth Amendment claims of junior high school student and upholding school's random drugtesting of student athletes participaung in interscholastic sports).

Even more, lawmakers have widely redefined children in criminal contexts as autonomous individuals. See, e.g., In re Gault, 387 U.S. 1, 55 (1967) (extending constitutional protection to children involved in delinquency proceedings). I am grateful to Professor Martin Guggenheim of New York University Law School for referring me to Robert A. Burt's article, The Constitution of the Family, which suggests that the Court's major concern in Gault was exerting control over children. See Robert A. Burt, The Constitution of the Family, 1979 Sup. Ct. Rev. 329, 345. Guggenheim and Burt are clearly correct in suggesting that the Court's jurisprudence involving children in the $1970 \mathrm{~s}$ was largely instrumental. Yet, cases such as In re Gault, and Bellotti II encouraged a general tendency within society to redefine children in certain contexts.

In recent years, state lawmakers have begun to dismantle a juvenile justice system, constructed over a century ago, that presumed that disorderly children should be protected and rehabilitated, rather than punished, by the state. In place of that system and that presumption, lawmakers are now placing young offenders in the adult criminal justice system and redefining them as indistinguishable from adult criminals. See, e.g., Mo. Rev. Stat. \$211.071.1 (1996) (providing juvenile court with discretion to transfer minor charged with committing a felony to a court of general jurisdiction for trial as an adult); see also Jacqueline Cuncannan, Note, Only When They're Bad: The Rights and Responsibilities of Our Children, 51 Wash. U. J. Urb. \& Contemp. L. 273, 274 n.7 (1997) (analyzing changes in Missouri law on juvenile waiver hearings). The 1996 Missouri statute lowered from fourteen to twelve the age at which a child could be eligible for a waiver hearing (and thus eligible to be tried as an adult). Id. The law also makes waiver hearings mandatory with regard to a set of serious crimes including murder, rape, and assault. Id. A few states do not limit by age or by type of crime the prosecution of a minor as an adult. See, e.g., Alaska Stat. $\$ 47.12 .100$ (Lexis 2000); Wyo. Stat. Ann. $§ 14-6-237$ (Lexis 2001). 
More specifically, the Court has sometimes presumed that extending constitutional rights to children serves their best interests. Yet, in other, similar cases, the Court has refused to extend constitutional rights to children. For instance, in Tinker v. Des Moines Independent Community School District, the Court safeguarded the right of children in school to wear armbands symbolizing opposition to U.S. involvement in Vietnam. ${ }^{144}$ Yet, in Vernonia School District 47J v. Acton, the Court treated school children differently than it treats adults and concluded that it was constitutional for a school district to perform random drug tests on certain groups of children because of the "government's responsibilities . . . as guardian and tutor of children entrusted to its care."145 Similarly, inconsistent understandings of children emerge from comparing Bellotti $v$. Baird (Bellotti II) ${ }^{146}$ with Parham v.J.R.147 These cases were decided in the same year. Nonetheless, in Bellotti II, the Court recognized the right of mature minors to make medical decisions without parental consent. ${ }^{148}$ In contrast, in Parham, the Court invoked the presumption that "parents generally do act in the child's best interests" 149 and upheld a state statute that allowed parents to commit a child to a state mental hospital. ${ }^{150}$ In sum, raising constitutional questions about the meaning and parameters of childhood has resulted in a murky, inconsistent jurisprudence of childhood.

\section{Troxel v. GRANVille: The Facts and the LAW}

Troxel v. Granville, decided by the Supreme Court in 2000, illustrates the confused state of the Court's constitutional jurisprudence respecting children in families. In Troxel, the Court found Washington State's nonparental visitation statute unconstitutional as applied to one mother. ${ }^{151}$ For a variety of reasons-some unintentional, some probably intentional-the decision provides little practical guidance to legislatures or lower courts considering the construction or interpretation of nonparental visitation statutes. Indeed, the significance of the Court's decision in Troxel lies largely in what it fails to do, and in what it thereby implies about the law's confused understanding of family. Troxel does not reflect a coherent vision of family (or of the parent-child relationship, in particular). Instead, it reflects a set of disharmonious assumptions about domestic matters. These assumptions structure the ideological dynamic

144. Tinker, 393 U.S. at 504-14.

145. Acton, 515 U.S. at 665.

146. 443 U.S. 622 (1979).

147. 442 U.S. 584 (1979).

148. 443 U.S. at 651.

149. 442 U.S. at $602-03$.

150. 1d. at 620-21. The specific question at issue in Parham was whether or not the Constitution required an adversary hearing for a child whose parent sought admission of the child to a state administered mental health facility. Id. at 587.

151. 530 U.S. 57,73 (2000). 
in terms of which Americans widely understand families (however confusedly), and in terms of which they respond to questions about specific families or about families in general. Moreover, the Court's plurality opinion, written by Justice O'Connor, articulates no general legal rules or clear guide for lower courts confronting the same type of legislation that was at issue in Troxel. Finally, the absence of a majority opinion gives additional leeway to legislatures and lower courts to interpret the decision inconsistently.

Despite its flaws as a legal decision, however, the case provides a set of texts of great use to analysts of the American family. The social and legal facts at issue in Troxel illuminate many of the contradictions that have come increasingly to define the domestic arena in the United States, and in the Western world more broadly, in the last several decades. The six separate opinions (two concurring with the plurality and three dissenting) that compose Troxel reveal a great deal about the shifting ideological parameters of familial relationships in American society. The opinions also illustrate the inability of constitutional law to resolve most family disputes because that task necessitates a much more coherent theory of childhood and of the parent-child relationship than the Court (and society more generally) has developed. Far more than cases involving familial choices by adults, cases involving children and the parentchild relationship have resisted satisfactory resolution by constitutional principles because they involve precisely those aspects of the larger "debate about family" that most bewilder Americans.

Troxel developed from a family dispute in Washington between the mother of two young girls and their paternal grandparents. ${ }^{152}$ Washington had unusually broad nonparental visitation statutes that permitted any person to petition at any time for visitation privileges with any child, and that did not require that the petitioner show that the child or children involved would be harmed should visitation not be ordered. ${ }^{153}$

152. Id. at 60-61.

153. Wash. Rev. Code Ann. $\$ 26.10 .160$ (3) (West 1997); Wash. Rev. Code Ann. $\$ 26.09 .240$ (West 1995) (amended 1996). These statutes "allow[ed] 'any person' to petition for forced visitation of a child at 'any time' with the only requirement being that the visitation serve the best interest of the child. There [was] no threshold requirement of a finding of harm to the child as a result of the discontinuation of visitation." In re Custody of Smith, 969 P.2d 21, 30 (Wash. 1998) (quoting $\$ \S 26.10 .160(3), 26.09 .240$ ). Only section 26.10.160(3) was at issue before the United States Supreme Court. That statute read, in relevant part: "Any person may petition the court for visitation rights at any time including, but not limited to, custody proceedings. The court may order visitation rights for any person when visitation may serve the best interest of the child whether or not there has been any change of circumstances." Wash. Rev. Code Ann. $\$ 26.10 .160$ (3). Due to an amendment, the language of section 26.09 .240 , beginning in 1996, was similar to that of section 26.10.160(3). Before section 26.09.240 was amended in 1996, it read:

The court may order visitation rights for a person other than a parent when visitation may serve the best interest of the child whether or not there has been any change of circumstances. A person other than a parent may petition the court for visitation rights at any time. The court may modify an order granting or 
This Part provides background to Troxel. First, it reviews the history of nonparental visitation statutes in the United States. Next, it describes the Troxel/Granville/Wynn family and the relationships of those involved in the litigation to each other. Finally, this Part summarizes the responses of the Washington state courts to the nonparental visitation statute at issue in the case and to the Troxel family.

\section{A. Statutory History}

The history of nonparental (and especially grandparent) visitation statutes suggests that, in drafting them, legislators responded directly to shifts in the demographics of family life during the last decades of the twentieth century. Common law provided no protection even to grandparents seeking relationships with grandchildren if the parents of those children opposed such relationships. ${ }^{154}$ The first state statutes providing for grandparent and other "third party" visitation were promulgated in the mid-1960s. ${ }^{155}$ By the end of the twentieth century, nonparental visitation statutes existed in every state. ${ }^{156}$ These statutes vary widely. Some provide exclusively for grandparent visitation; ${ }^{157}$ others, such as that at issue in Troxel, are much broader. ${ }^{158}$ Some take effect only when a parent is unmarried, divorced or dead. ${ }^{159}$ All require courts to consider the best interests of the child or children involved; the vast majority do not require a showing of harm to the child. ${ }^{160}$

As a group, these statutes reflect several specific shifts in the demographics of domestic life as well as a less concrete transformation in the meaning of family after the middle of the twentieth century. First, the traditional nuclear family-always less prevalent than society's por-

denying visitation rights whenever modification would serve the best interests of the child.

Id. $\$ 26.09 .240$ (amended 1996).

154. Maegen E. Peek, Note, Grandparent Visitation Statutes: Do Legislatures Know the Way to Carry the Sleigh Through the Wide and Drifting Law?, 53 Fla. L. Rev. 321, 324 (2001).

155. Sara Elizabeth Culley, Troxel $v$. Granville and its Effect on the Future of Grandparent Visitation Statutes, 27 J. Legis. 237, 238 (2001).

156. Id. at 238-39.

157. See M. Kristine Taylor Warren, Grandparent Visitation Rights: A Legal Research Guide 3-18 (2001) (comparing the nonparental visitation statutes of various states). In addition to state statutes, Congress amended the Parental Kidnaping Prevention Act of 1980, 28 U.S.C. $\$ 1738$ A (1994), by passing the Visitation Rights Enforcement Act of 1998, Pub. L. No. 105-374, 112 Stat. 3383. The amendment made it clear that grandparents should be included among those who may have custodial or visitation rights, and that any such court-ordered rights should be enforced in any state to which a child is moved. Id.

158. See supra note 153 (describing the statute at issue in Troxel).

159. Warren, supra note 157 , at 1 .

160. AARP Foundation Litigation, Comparison of Grandparent Visitation Statutes Nationwide, at http://www.aarp.org/litigation/table.html (last visited Oct. 17, 2001) (on file with the Columbia Law Review). Georgia's statute conditions court-ordered grandparent visitation on a showing of harm to the "health or welfare of the child" if visitation is not granted. Ga. Code Ann. $§ 19-7-3$ (c) (1999). 
trait of an ideal family often suggested-is clearly not the norm any longer. ${ }^{161}$ lncreasing rates of divorce and separation, and an increasing incidence of nonmarital families, have contributed to this shift.162 Nonparental visitation statutes reflect these demographic changes in that they diminish parental authority to regulate a child's relationships with grandparents and other "third parties." Moreover, they reflect the shift toward "blended" families within which children may be raised by parents, step-parents, older siblings (including step-siblings), and others, including grandparents.

Further leading to the promulgation of such statutes, relationships between children and their grandparents have been affected by patterns of residential mobility that often result in children living significant distances from their grandparents. This mobility has often precluded the development and sustenance of traditional grandchildren-grandparent relationships. ${ }^{163}$ In fact, the work of organized groups of grandparents such as the American Association of Retired People (AARP) ${ }^{164}$ has provided a strong lobby that has convinced state legislators to promulgate nonparental, and especially grandparent, visitation statutes in order to counter the threat geographic mobility and other factors present to relationships between grandparents and their grandchildren. ${ }^{165}$

Not only were such nonparental visitation statutes appealing to the legislatures that enacted them, they were also found constitutional by most of the state courts that considered them before the Supreme Court

161. Culley, supra note 155 , at 239. Results of the 2000 Census show that less than twenty-five percent of U.S. households are composed of married couples and their children. See, e.g., Whatever Happened to the Nuclear Family?: 2000 Census Report on Families, Food Processing, Aug. 2001, LEXIS, News Library ALLNWS File.

162. Warren, supra note 157, at xiii-xiv; Culley, supra note 155, at 239.

163. Warren, supra note 157 , at xiii. In 1986, Nebraska State Senator Lowell Johnson declared:

The rapid social changes affecting our families over several decades threaten the generation bond as most of us have known it. Today's increased mobility and high divorce rates, separations and family abuse problems have tended to separate millions of children from relatives of an older generation who have traditionally served as the emotional buffers between generations as well as custodians of family history and culture.

Rochelle Bobroff, The Survival of Grandparent Visitation Statutes, 34 Clearinghouse Rev. 284, 287 (quoting Hearing on L.B. 105 Before the Senate, 89th Leg., lst Sess. 88-89 (Neb. 1985) (statement of Sen. Lowell Johnson)).

In addition, increases in life expectancy have contrihuted to the number of living grandparents. See id. at 284.

164. See Bobroff, supra note 163 , at 285-87. Several groups representing grandparents presented amicus briefs to the Supreme Court in Troxel. See, e.g., Amicus Curiae Brief, AARP and Generations United in Support of Petitioners, Troxel v. Granville, 530 U.S. 57 (2000) (No. 99-138) [hereinafter Troxel AARP Amicus Brief]; Amicus Curiae Brief, Grandparent Caregiver Law Center of the Brookdale Center on Aging, Troxel v. Granville, 530 U.S. 57 (2000) (No. 99-138); Amicus Curiae Brief, Grandparents United for Children's Rights, Inc., Troxel v. Granville, 530 U.S. 57 (2000) (No. 99-138).

165. Peek, supra note 154 , at 324-26. 
decided Troxel. ${ }^{166}$ Moreover, of the courts that invalidated such statutes before Troxel, most either suggested expressly or implicitly that amended versions of the statutes-reflecting more careful drafting in light of the specific interests at stake-would be constitutional, ${ }^{167}$ or issued narrow rulings that often suggested this same conclusion. ${ }^{168}$

The widespread acceptability to legislators and state courts of ordering nonparental visitation despite parental resistance clearly indicates a significant shift in conceptions of the family, and of the parent-child relationship in particular, since the middle of the twentieth century. Such statutes would have been anathema to an earlier age that presumed the ideal, if not the uniform, existence of traditional nuclear families, and in tune with that presumption assumed, even if not always correctly, that two married parents, if fit, would be better able to raise their biological children within nuclear households without interference from other family members or the state. ${ }^{169}$ In that earlier age, only such parents were to decide with whom their children would, and would not, associate. ${ }^{170}$

\section{B. The Troxel "Family"}

The disputants in Troxel themselves further illustrate the background of shifting family structures against which legislatures have promulgated nonparental visitation statutes. Family members relevant to the litigation included Tommie Granville, mother of Isabelle and Natalie Troxel, and

166. See, e.g., In re Graville, 985 P.2d 604, 611 (Ariz. Ct. App. 1999) (upholding grandparent visitation statute and noting that "the majority of the courts in the nation ... have upheld similar grandparent visitation statutes"); Ridenour v. Ridenour, 901 P.2d 770, 774 (N.M. Ct. App. 1995) (noting in case involving nonparental visitation statute that "[a] majority of courts which have considered this issue have rejected similar or related constitutional challenges"); Peek, supra note 154, at 353 (describing judicial responses to grandparent visitation statutes before Supreme Court decision in Troxel).

167. See, e.g., Hoff v. Berg, 595 N.W.2d 285, 291 (N.D. 1999) (noting that “[m] ethods to promote grandparental visitation can be more narrowly tailored and still reasonably accomplish the legislative purpose behind [the state's statute]"); Peek, supra note 154, at 353 ("Even in cases finding the statutes unconstitutional, those courts . . make narrow rulings ... or indicate a willingness to approve more narrowly tailored statutes ...."). Hoff involved a North Dakota grandparent visitation statute that directed state courts to order grandparent visitation with unmarried minors "unless a finding is made that visitation is not in the best interests of the minor." 595 N.W.2d at 287 (quoting N.D. Cent. Code $\$ 14$ 09-05.1 (1997)). The statute further presumed that grandparent visitation was "in the best interests of the minor child." Id. at 291.

168. See, e.g., Hawk v. Hawk, 855 S.W.2d 573, 577 (Tenn. 1993) (invalidating statute under state constitution). The court in Hawk concluded that providing for a child's "best interests" was not a compelling state interest in the context of nonparental visitation. Id. The court limited its holding, however, to this case of a "married couple, whose fitness as parents is unchallenged." Id.; see also Peek, supra note 154, at 353 (considering general readiness of state courts to uphold grandparent visitation statutes).

169. Ellman et al., supra note 82 , at 724 (considering custody disputes involving parents and nonparents).

170. See supra Part I (describing assumptions about family in nineteenth century and first half of twentieth century). 
the girls' paternal grandparents, Jenifer and Gary Troxel. ${ }^{171}$ The "family" at issue in the case also involved Brad Troxel, the girls' dead father, who had committed suicide in 1993. ${ }^{172}$

Tommie and Brad had lived together for several years, beginning in $1988^{173}$ or $1989 .{ }^{174}$ Natalie was born in late $1989 .{ }^{175} \mathrm{Brad}$ and Tommie separated six months before Isabelle's birth in late 1991. ${ }^{176}$ Between 1991 and 1993 (when he killed himself), Brad lived with his parents. Isabelle and Natalie spent weekends with them. ${ }^{177}$ These visitations continued for five months after Brad's death. ${ }^{178}$ Then, in October 1993, Tommie decided to limit the time her daughters spent with their paternal grandparents. ${ }^{179}$ Two months later, the Troxels commenced litigation, asking a Washington superior court to order Tommie Granville to arrange visits between her daughters and the Troxels two weekends each month and two weeks each summer. ${ }^{180}$ By this time, Tommie had married Kelly Wynn, ${ }^{181}$ who adopted the Troxel girls in $1996 .{ }^{182}$ The Wynn family now included six children in addition to Natalie and Isabelle (three from Tommie's first marriage, two from Kelly's prior marriage, and one born to Tommie and Kelly). ${ }^{183}$

Tommie was willing to allow Natalie and Isabelle to see their father's parents, but opposed overnight visits during the girls' childhood years. ${ }^{184}$ She was concerned that the Troxels saw Natalie and Isabelle as a substitute for their dead son. ${ }^{185}$ There were apparently no other major disagreements between the parties about how the girls should be raised, and the Troxels did not question Tommie's fitness as a mother. ${ }^{186}$

171. Troxel v. Granville, 530 U.S. 57, 60 (2000).

172. Id.

173. Brief for Petitioners at 2, Troxel v. Granville, 530 U.S. 57 (2000) (No. 99-138) [hereinafter Troxel Brief for Petitioners].

174. Brief for Respondent at 8, Troxel v. Granville, 530 U.S. 57 (2000) (No. 99-138) [hereinafter Troxel Brief for Respondent].

175. Troxel Brief for Petitioners, supra note 173 , at 2.

176. Id.; Troxel, 530 U.S. at 60.

177. Troxel, 530 U.S. at 60 .

178. 1d. at $60-61$.

179. Troxel Brief for Petitioners, supra note 173, at 2.

180. Troxel, 530 U.S. at 61.

181. Id. at 62. Tommie Granville changed her name to Tommie Wynn after her marriage to Kelly Wynn. For the sake of consistency, however, this Article will refer to her throughout as Tommie Granville.

182. Troxel Brief for Respondent, supra note 174 , at 10 .

183. James V. Grimaldi, Justices Question Grandparents' Rights Argument, Seattle Times, Jan. 12, 2000, at A1.

184. Troxel Brief for Petitioners, supra note 173 , at 3.

185. Grimaldi, supra note 183.

186. Troxel Brief for Petitioners, supra note 173, at 3-4. 


\section{The Troxel Dispute in the State Courts}

The Troxel dispute was first argued before Judge Rickert of the Washington Superior Court of Skagit County. The trial court, choosing a middle ground between Tommie's visitation proposal and that sought by the Troxels, ordered visitation one weekend each month, one week in the summer, and on the grandparents' birthdays. ${ }^{187}$ The court concluded that such visitation was in the best interests of the children:

The court took into consideration all factors regarding the best interest of the children and considered all the testimony before it. The children would be benefitted from spending quality time with the Petitioners, provided that that time is balanced with time with the childrens' [sic] nuclear family. The court finds that the childrens' [sic] best interests are served by spending time with their mother and stepfather's other six children. ${ }^{188}$

Ms. Granville appealed. On appeal, the state appellate court reconstrued the relevant statute to preclude what it described as an "absurd result." 189 Could one imagine, the court asked, that the legislature intended to grant " any person'" "standing to petition 'at any time' for visitation with a child?" 190 The court continued: "For example, could a member of the state Legislature who has displeased a constituent find herself faced with the considerable expenditure of time, money, and emotional energy to oppose a wholly frivolous petition by that constituent?" 191 In light of such possibilities, the appellate court concluded that the state legislature "could not have intended such an absurd and potentially pernicious result." 192 Thus, despite the clear language of the nonparental visitation statute, the appellate court read it to limit petitions for visitation to cases involving custody proceedings. ${ }^{193}$

187. Troxel, 530 U.S. at 61; In re Visitation of Troxel, 940 P.2d 698, 699 (Wash. Ct. App. 1997), corrected, 971 P.2d 56 (Wash. Ct. App. 1998).

188. Findings of Fact and Conclusions of Law Dated and Filed January 3, 1996, in re Visitation of Troxel (Wash. Super. Ct. Dec. 14, 1994) (No. 93-3-00650-7), reprinted in Joint App., at 68a, 70a, Troxel v. Granville, 530 U.S. 57 (2000) (No. 99-138).

The original trial court decision was rendered orally. Granville appealed, and the Washington Court of Appeals remanded for written findings of fact and conclusions of law. Troxel, 530 U.S. at 61.

For consideration of the decision of the Troxel trial court in greater depth, see infra Part V (analyzing United States Supreme Court's decision in Troxel).

189. In re Visitation of Troxel, 940 P.2d at 699.

190. Id. (quoting Wash. Rev. Code Ann. $\$ 26.10 .160(3)$ (West 1997)).

191. Id.

192. Id. at 700 .

193. Id. at 701. The appellate court also noted that a parallel statute, section 26.09.240 of the Revised Code of Washington, was amended in 1996 so as to limit petitions for visitation to cases in which "the child's parent or parents have commenced an action under this chapter." Id. at 700 (quoting Wash. Rev. Code $\$ 26.09 .240$ ). The amendment required a court to dismiss a proceeding under the provision unless the petitioner "can demonstrate by clear and convincing evidence that a significant relationship exists with the child with whom visitation is sought." $1 \mathrm{~d}$. (quoting Wash. Rev. Code $\$ 26.09 .240$ ). The 
On appeal, the Washington Supreme Court consolidated the Troxels' petition with two other visitation cases. ${ }^{194}$ The court refused to reconstrue the "plain language" of the statute, and thus concluded that the statute, as written, provided petitioners with standing to seek visitation with the children involved. ${ }^{195}$ The court, however, also found the statute to be an unconstitutional violation of a parent's fundamental right to raise children free from state interference. ${ }^{196}$ In particular, the state supreme court focused on the statutory absence of a "threshold requirement of a finding of harm to the child as a result of the discontinuation of visitation." 197 "Short of preventing harm to the child," the court explained, "the standard of 'best interest of the child' is insufficient to serve as a compelling state interest overruling a parent's fundamental rights." 198

Dissenting, Justice Talmadge focused on the shifting "realities and complexities" of contemporary family life. ${ }^{199} \ln$ particular, the dissent asserted that the majority's conclusions presumed a traditional nuclear family. ${ }^{200}$ Justice Talmadge argued that as that form of family becomes the exception rather than the norm, the law must heed the rights of children to preserve "close extra parental relationship [s]"201 forged in families that differ from those representative of most of the nineteenth and twentieth centuries.

Grandparents Jenifer and Gary Troxel next appealed the state supreme court judgment to the U.S. Supreme Court. The Court granted certiorari in $1999^{202}$ and ruled on the appeal in June 2000. ${ }^{203}$

appellate court concluded that the legislative failure to amend section $26.10 .160(3)$ of the Revised Code of Washington in a similar fashion "was the result of an unintentional oversight." Id.

194. In re Custody of Smith, 969 P.2d 21, 23 (Wash. 1998); see also Troxel v. Granville, 530 U.S. 57, 62 (2000) (noting consolidation). In one of the cases heard with Troxel, the cohabitant of a young boy's mother petitioned for visitation with the child after the relationship between the adults ended. Smith, 969 P.2d at 23 . In the second, relatives of a child's dead father petitioned for visitation with the child. 1d. at 24. This case involved atypical facts, and was complicated for several reasons. First, the child, conceived through artificial insemination, was not the husband-father's biological child. Id. Second, this man was shot by the child's maternal grandmother, whom he, in turn shot. Both died as a result of the shootings. Id.

195. Smith, 969 P.2d at $26-27$.

196. Id. at $30-31$.

197. Id. at 30 .

198. Id. The court further opined that, to pass constitutional review, nonparental visitation statutes should require petitioners to show "a substantial relationship with the child" and require courts to consider "the parents' reasons for restricting visitation with the petitioner or any allegations of past physical or mental abuse by petitioner." Id. at 31 .

199. Id. at 38 (Talmadge, J., dissenting).

200. Id. (Talmadge, J., dissenting).

201. Id. at 39 (Talmadge, J., dissenting).

202. Troxel v. Granville, 527 U.S. 1069, 1069 (1999).

203. Troxel v. Granville, 530 U.S. 57, 75 (2000). 


\section{The Supreme Court's Opinions in Troxel: Illuustrating the Limitations of Constitutional Law as an Arbiter of Disputes Involving Children and Childhood}

The Court's plurality decision in Troxel reflects both a set of assumptions about family that justifies the promulgation of nonparental visitation statutes and a set of contrary assumptions that challenges such statutes as essentially disadvantageous to the preservation of healthy families. In justifying its conclusion, the plurality invoked a fairly long set of prior Supreme Court decisions interpreting the Fourteenth Amendment's Due Process Clause to protect parents' "liberty interests" in the "care, custody, and control of their children."204 Yet the Troxel plurality refrained from examining the implications of that protection for nonparental visitation statutes in general. Instead, the plurality focused on one aspect of the Troxel-Granville narrative, and concluded that Washington's visitation statute, "as applied," infringed on Tommie Granville's fundamental right to make decisions about which relatives could spend time with her daughters. ${ }^{205}$

This Part considers Troxel in detail in order to show the inability of constitutional law adequately to confront the questions defining the contemporary debate about family (especially with respect to children in families). This Part presents three broad arguments in support of that conclusion. First, Troxel gives minimal guidance to lower courts and legislatures. The decision, read as a set of six contrasting opinions, ${ }^{206}$ is susceptible to diverse, even contradictory, interpretations. No majority coalesced, and the decision as a whole is comprised of six significantly different views of the social and jurisprudential issues under consideration. ${ }^{207}$ Second, the plurality itself failed to establish a firm jurisprudential frame within which to judge the constitutionality of nonparental visitation statutes. Its opinion presents three contrasting models of family and then vacillates among them before finally relying on one to resolve the issues at stake in the case. Third, the plurality's support for the nuclear model of family it ultimately chooses is confused and inconsistent.

204. Id. at 65-66 (plurality opinion); see infra note 274 (delineating cases cited by plurality).

205. Troxel, 530 U.S. at 75 (plurality opinion).

206. Justice O'Connor's plurality opinion was joined by Chief Justice Rehnquist, Justice Ginsburg, and Justice Breyer. Id. at 60 (plurality opinion). Justice Souter wrote a concurring opinion, id. at 75 (Souter, J., concurring), as did Justice Thomas, id. at 80 (Thomas, J., concurring). Separate dissents were authored by Justice Stevens, id. (Stevens, J., dissenting), Justice Scalia, id. at 91 (Scalia, J., dissenting), and Justice Kennedy, id. at 93 (Kennedy, J., dissenting).

207. As Justice Thomas noted in his concurring opinion, Troxel does not, for instance, even indicate the Court's position with regard to the continuing viability of a substantive due process approach, since none of the parties argued that issue. ld. at 80 (Thomas, J., concurring). 


\section{A. The Opinions}

The Court held Washington's nonparental visitation statute unconstitutional as applied to Tommie Granville. ${ }^{208}$ The plurality concluded that the Washington State Superior Court interfered unconstitutionally with Tommie Granville's fundamental right as a parent to make decisions about who could associate with her children. ${ }^{209}$ In particular, the decision focused on the trial court's failure to presume that the decisions of a fit mother served the best interests of her children. ${ }^{210}$ The plurality expressly declined to decide more broadly when, if ever, nonparental visitation statutes would pass constitutional muster or to define the limits of the parental due process right in the context of nonparental visitation statutes. ${ }^{211}$

Justices Souter and Thomas concurred in the plurality's judgment, though only Justice Souter supported the plurality's reasoning. Reflecting the plurality's ostensible approach, ${ }^{212}$ Justice Souter framed the case in terms of protections extended by the Court under the umbrella of substantive due process rights. ${ }^{213}$ Unlike the plurality, however, he would have affirmed the decision of the state supreme court that invalidated the statute on its face because of the statute's overly broad sweep (authorizing "any person" at "any time" to seek visitation). ${ }^{214}$ Justice Thomas concurred on the ground that the Court's substantive due process precedents necessitated his doing so, but he expressly noted the possibility that those precedents were wrongly decided and should be reexamined in an appropriate context. ${ }^{215}$

Three Justices wrote dissenting opinions. ${ }^{216}$ Justice Stevens agreed with Justice Souter that the plurality's "as applied" decision was inappropriate because it depended on "a guess" about the state court's application of the relevant statute, and on the Justices' "assessment of the facts in this case." 217 In Justice Stevens's view, both tasks should have been left to

208. Id. at 75 (plurality opinion).

209. Id. at 63 (plurality opinion)

210. Id. at 72 (plurality opinion) (noting failure of Washington Superior Court "to accord the determination of Granville, a fit custodial parent, any material weight").

211. Id. at 73 (plurality opinion) (noting Court's hesitation "to hold that specific nonparental visitation statutes violate the Due Process Clause as a per se matter").

212. Use of the phrase "ostensible approach" is intended to suggest that the approach followed by the Court is not deeply anchored in any clear jurisprudential frame. See infra notes 273-279 and accompanying text (considering implications of Court's invocation of substantive due process in Troxel).

213. Troxel, 530 U.S. at 77 (Souter, J., concurring).

214. 1d. at 76-77, 79 (Souter, J., concurring).

215. 1d. at 80 (Thomas, J., concurring) (noting that "neither party has argued that our substantive due process cases were wrongly decided and that the original understanding of the Due Process Clause precludes judicial enforcement of unenumerated rights under that constitutional provision").

216. See supra note 206.

217. Troxel, 530 U.S. at 81-82 (Stevens, J., dissenting). 
state courts. ${ }^{218}$ Unlike Justice Souter, however, Justice Stevens rejected the state supreme court's interpretation of the U.S. Constitution. According to Justice Stevens, a facial challenge to the statute could not be countenanced because of the statute's "plainly legitimate sweep."219 In addition, Justice Stevens found no basis for the state supreme court's conclusion that court-ordered nonparental visitation must be premised on a showing that the child would, or might, be harmed if visitation were denied.220 Thus, Justice Stevens would have remanded the case, asking the state court to construe the statute's meaning (and, in particular, to discern the meaning of the phrase "best interest of the child"), and then to reexamine the trial court's disposition in light of its own statutory construction. 221

In contrast, Justice Scalia's dissent called for overturning the state supreme court decision on the ground that the judiciary lacks a constitutional mandate to identify and enforce parental rights. ${ }^{222}$ Finally, Justice Kennedy's dissent called for vacating and remanding the case. ${ }^{223}$ He disagreed with the lower court's conclusion that the Constitution mandates a requirement of harm or potential harm to the child before a court can order nonparental visitation. ${ }^{224}$ Justice Kennedy would, therefore, have asked the Washington Supreme Court to reconsider the case in light of the protections afforded the parties by the trial court. ${ }^{225}$

The multifaceted disagreements among members of the Courtabout whether to consider the case, how to consider it, and what the Court was obliged to decide or to leave undecided-reflect wider disagreements within society, not only about familial matters but, far more broadly, about the viability of a set of social institutions and institutionalized beliefs that anchored American society in an earlier age.

\section{B. The Three Models of Family Underlying Troxel}

The confusion in society and the law about the changing scope of families is illuminated, not only by the many opinions and visions of family comprising Troxel, but also by the appearance of several distinct conceptions of family in the plurality opinion itself. 226 Three distinct per-

218. 1d. at 80-81 (Stevens, J., dissenting).

219. 1d. at 85 (Stevens, J., dissenting) (quoting Washington v. Glucksberg, 521 U.S. 702,740 n.7 (1997) (Stevens, J., concurring) (quoting Broadrick v. Oklahoma, 413 U.S. $601,615(1973)))$.

220. Id. at 85-86 (Stevens, J., dissenting).

221. Id. at 83-85 (Stevens, J., dissenting).

222. Id. at 91-92 (Scalia, J., dissenting).

223. Id. at I02 (Kennedy, J., dissenting).

224. 1d. at 94-96 (Kennedy, J., dissenting).

225. Id. at 94-95, 102 (Kennedy, J., dissenting).

226. At the start of its substantive discussion, the plurality described an unstable social reality that motivated legislators to provide for nonparental visitation. Id. at 63-64 (plurality opinion). Concern about the implications of that reality is reflected as well in the Court's own divided and confused responses to the issues raised by Troxel. 
spectives about family underlie that opinion. Each perspective is reflected as well in some or all of the concurring and dissenting opinions in the case. Justice O'Connor invoked and gave credence to each of three perspectives: the individualist model of family, the nuclear model of family, and the model of family as an extended network of loving kin. Each model provides the ideological frame within which the Court responded to at least some questions about family matters in cases that preceded Troxel. Nonetheless, the plurality did not seriously analyze the contradictions among the models. The Court's judgment reflects one perspective, and thus implicitly rejects, or at least downplays, the significance of the other perspectives. However, nowhere in its opinion did the plurality expressly consider its choice among perspectives as a choice.

This Section examines the three models of family that appear in Troxel and the dialogue the plurality constructed in order to illustrate the presumed superiority of one model over the others.

1. The Individualist Model of Family. - An individualist model of family assumes the autonomy of family members vis-à-vis one another and values the right of each individual to make familial choices, unfettered by tradition or by state interference. This model is central to the debate about family within American society and to a set of Supreme Court decisions involving the rights of adults to negotiate their own reproductive choices. ${ }^{227}$

The Troxel plurality acknowledged this model as an increasingly accurate representation of contemporary family life, but did not present it as a reasonable model with which to regulate the scope of relationships among parents and other family members, such as grandparents and children. The plurality did acknowledge that social changes consistent with this model explained the proliferation of nonparental visitation statutes among the states; but it encapsulated the individualist model of family as mere background material:

The demographic changes of the past century make it difficult to speak of an average American family. The composition of families varies greatly from household to household. While many children may have two married parents and grandparents who visit regularly, many other children are raised in single-parent households. In 1996, children living with only one parent accounted for 28 percent of all children under age 18 in the United States. Understandably, in these single-parent households, persons outside the nuclear family are called upon with

227. See, e.g., Roe v. Wade, 410 U.S. 113, 164-66 (1973) (extending limited constitutional right to abortion); Eisenstadt v. Baird, 405 U.S. 438, 454-55 (1972) (invalidating state prohibition on the distribution of contraceptives to unmarried adults); Griswold v. Connecticut, 381 U.S. 479, 485-86 (1965) (invalidating state prohibition on the distribution of contraceptives to married individuals); see also supra notes 112-123 and accompanying text (describing these decisions). 
increasing frequency to assist in the everyday tasks of child rearing. ${ }^{228}$

As did the plurality, Justice Kennedy, in his dissent, referred to the significance of recent changes in the shape of the American family for the law's regulation of family matters. "For many boys and girls," he noted, "a traditional family with two or even one permanent and caring parent is simply not the reality of their childhood."229 In large part, the specific changes in the lives of children to which Justices O'Connor and Kennedy referred have resulted from the widespread redefinition of adults within families as autonomous individuals because, inevitably, new choices appropriated by adults in families have shaped and redefined the lives of their children. ${ }^{230}$

Despite acknowledging its significance, the plurality clearly considered the individualist model to be disruptive to families, and in particular to children in families, and thus the plurality turned, almost immediately, to the task of correcting-or at least discerning how best to live with-the disruptions in traditional understandings of family effected by individualism. ${ }^{231}$

2. The Nuclear Model of Family. - The second (nuclear) model of family ideally includes two parents of opposite genders and their dependent, treasured biological or adopted children. ${ }^{232}$ This model provides

228. Troxel, 530 U.S. at 63-64 (plurality opinion) (citation omitted).

229. Id. at 98 (Kennedy, J., dissenting).

230. For example, Whitehead comments that in the second half of the twentieth century:

Americans began to change their ideas about the individual's obligations to family and society. Broadly described, this change was away from an ethic of obligation to others and toward an obligation to self. . .

This ethical shift had a profound impact on ideas about the nature and purpose of the family. ... Once the domain of the obligated self, the family was increasingly viewed as yet another domain for the expression of the unfettered self.

Whitehead, supra note 4 , at 4-5.

231. After alluding to the individualist model (through reference to its role in effecting broad shifts in the demographics of American family life), the plurality avoided considering the model further. In particular, the opinion did not consider the implications of the shifting scope of childhood in American society, and did not consider the place, if any, for children's voices in familial decisions of the sort at stake in Troxel. Justice Kennedy's dissenting opinion referred to the child as the often-forgotten third party in cases such as Troxel:

Cases like this do not present a bipolar struggle between the parents and the State over who has final authority to determine what is in a child's best interests. There is at a minimum a third individual, whose interests are implicated in every case to which the statute applies-the child.

Troxel, 530 U.S. at 86 (Kennedy, J., dissenting).

232. The nuclear family is sometimes referred to as a "modern" family as compared with "postmodern" families. In that use, the term "modern" reflects the universe of the nineteenth and early twentieth centuries within which the Industrial Revolution developed and flourished. Judith Stacey describes "an intact nuclear household unit" as composed of "a male breadwinner, his full-time homemaker wife, and their dependent children." 
no place for children's voices or for recognition of children's personhood except insofar as that personhood is implied and encompassed by the broad status that defines all children similarly. Thus, within the frame established by this model, it was unnecessary to differentiate the voice of any child from that of any other; and the voice of children as a group was subordinated to that of their presumptively caring, affectionate parents. ${ }^{233}$ The nuclear model undergirds the opinions of the Court in both Meyer $v$. Nebraska, ${ }^{234}$ decided in 1923, and Pierce v. Society of Sisters, ${ }^{235}$ decided in 1925. ${ }^{236}$ In both cases, the Court endorsed and reinforced parental authority vis-à-vis both children and the state. ${ }^{237}$

3. The Extended-Kin Model of Family. - A third model of family involves an extended network of presumptively loving kin. This model stresses the significance of a rich, loosely structured community of relatives, including especially grandparents and siblings, along with parents, who love and care for one another. The model resembles the nuclear model in that it does not value autonomous choice and marketplace negotiations within families.

Judith Stacey, Backward Toward the Postmodern Family: Reflections on Gender, Kinship, and Class in the Silicon Valley, in Rethinking the Family: Some Feminist Questions 91, 93 (Barrie Thorne \& Marilyn Yalom eds., rev. ed. 1992). Stacey further notes:

In 1950, three-fifths of American households contained male breadwinners and full-time female homemakers, whether children were present or not. By 1986, in contrast, more than three-fifths of married women with children under the age of eighteen were in the labor force, and only 7 percent of households conformed to the "modern" pattern of breadwinning father, homemaking mother, and one to four children under the age of eighteen. By the middle of the 1970 s, moreover, divorce outstripped death as the source of marital dissolutions, generating in its wake a complex array of family arrangements ....

1d. (footnotes omitted).

233. See Barhara Bennett Woodhouse, "Who Owns the Child?": Meyer and Pierce and the Child as Property, $33 \mathrm{Wm}$. \& Mary L. Rev. 995, 1001 (1992) (explaining that "the reverse side of the coinage of family privacy and parental rights" was "the child's voicelessness, objectification, and isolation from the community").

234. 262 U.S. 390 (1923); see also infra notes 257-265 and accompanying text (considering Meyer).

235. 268 U.S. 510 (1925); see also infra notes 257-265 and accompanying text (considering Pierce).

236. Before the second half of the twentieth century, the Supreme Court entertained few family law cases. See supra note 78 and accompanying text. Pierce and Meyer, both exceptions to that general pattern, have become important precedents for most of the later constitutional cases involving family matters, particularly those relating to parents and children. Pierce and Meyer might be seen as early indications of the Court's readiness to serve as a moral arbiter in matters involving children and kin relationships. Both cases resulted in clear statements by the Court about the strong, continuing power of parents, not the state, to make fundamental decisions involving children's schooling and socialization. See Pierce, 268 U.S. at 534-35; Meyer, 262 U.S. at 399-403.

237. See Woodhouse, supra note 233, at 997 (analyzing ideology underlying Court's decisions in Meyer and Pierce). 
The Court premised its 1977 decision in Moore v. City of East Cleveland on this third model of family. ${ }^{238}$ "Ours," the Court explained in Moore, "is by no means a tradition limited to respect for the bonds uniting the members of the nuclear family. The tradition of uncles, aunts, cousins, and especially grandparents sharing a household along with parents and children has roots equally venerable and equally deserving of constitutional recognition." 239 In theory, this model presents a reasonable response to widespread disruptions in traditional family life that Justice O'Connor described in Troxel. ${ }^{240}$ It has not, however, been widely reinforced by courts, including the Supreme Court, probably because it is not consonant with either the nuclear model of family-the most widely valued model of family before the second half of the twentieth century-or with America's increasing concern for autonomous individuality and choice. Furthermore, the sorts of families posited by Moore are difficult to define and thus difficult to regulate.

4. The Dialogue Between "Traditional" Models of Family: The Nuclear Model Versus the Extended-Kin Model. - Ultimately, the plurality preferred the nuclear-family model to that based around a network of extended kin. The plurality found wanting the trial court decision that favored a family of extended kin because that choice failed to defer adequately to the decision of a fit mother about her children's familial relationships. ${ }^{241}$ The plurality's conclusion that the trial court failed to pay adequate deference to Tommie Granville's preferences may, as Justice Stevens suggested, have been misplaced. ${ }^{242}$ But neither the relevance of the Court's

238. See 43I U.S. 494, 504 (plurality opinion) (1977). In Moore, the Court invalidated a city housing ordinance that defined "family" narrowly, depicting this third model as traditional. See id. (plurality opinion). The Court's depiction notwithstanding, the extended-kin model does not actually replicate the traditional ideal of a nuclear family so important to assessments of family life after the start of the nineteenth century. Yet, both the nuclear and the extended-kin models of family contrast with the individualist model in that they value families as holistic social units rather than as collections of autonomous individuals.

239. Id. (plurality opinion).

240. See Troxel v. Granville, 530 U.S. 57, 63 (2000) (plurality opinion) (describing "demographic changes of the past century [that] make it difficult to speak of an average American family").

24I. Id. at 69-70 (plurality opinion).

242. Id. at 82 n.2 (Stevens, J., dissenting). Justice Stevens expressly disagreed with Justice O'Connor's assessment of the trial court's presumptions about the benefits of grandparent visitation for the Troxel children. "I find no suggestion in the trial court's decision in this case," opined Justice Stevens, "that the court was applying any presumptions at all in its analysis, much less one in favor of the grandparents." Id. at 82 n.3 (Stevens, J., dissenting). Justice Stevens further explained:

The first excerpt Justice O'Connor quotes from the trial court's ruling . . . says nothing one way or another about who bears the burden under the statute of demonstrating "best interests." There is certainly no indication of a presumption against the parents' judgment, only a "commonsensical' " estimation that, usually but not always, visiting with grandparents can be good for children. The second quotation, "I think [visitation] would be in the best interest of the children and I 
legal claim, as a broad theoretical matter, nor the accuracy of the claim in Troxel specifically, seems central to the plurality's opinion, especially if that opinion is read not just as a legal text, but as a social text as well.

In effect, the Troxel plurality constructed a dialogue between these two "traditional" alternatives to the individualist model of family. The plurality focused on the trial court's having contravened a parental decision for the sake of "cousins and music." 243 So framed, Judge Rickert's analysis appears thoughtless, even inane. That portrait served an essential, though implicit, end for the plurality. It enabled the plurality to compare two models of family and to assert that one of them was significantly better than the other.

In comparing the models, the plurality focused in detail on Judge Rickert's decision for the Washington trial court, in effect constructing a dialogue between proponents of a nuclear model of family (presented sometimes through the voice of Tommie Granville and sometimes in the plurality's own voice) on one side, and proponents of a view of family as an extended network of kin (a view presented in Judge Rickert's voice) on the other side. ${ }^{244}$ The resulting dialogue constitutes the rhetorical dynamic around which the plurality explained its decision to declare Washington's nonparental visitation statute unconstitutional "as applied" to Tommie Granville. ${ }^{245}$

Justice O'Connor set the terms of the dialogue, between the Supreme Court (and Tommie Granville) on one side and the trial court on the other, with a summary of her own conclusions about Judge Rickert's decision. She focused on Judge Rickert's explanation of his best interest determination and portrayed differences between Tommie Granville and the judge as if they constituted some part of a larger familial dispute. ${ }^{246}$ In effect, the plurality merged the voice of Judge Rickert with the voices

haven't been shown it is not in [the] best interest of the children," sounds as though the judge has simply concluded, based on the evidence before him, that visitation in this case would be in the best interests of both girls. These statements do not provide us with a definitive assessment of the law the court applied regarding a "presumption" either way. Indeed, a different impression is conveyed by the judge's very next comment: "That has to be balanced, of course, with $\mathrm{Mr}$. and Mrs. Wynn [a.k.a. Tommie Granville], who are trying to put together a family that includes eight children ...."

Id. (Stevens, J., dissenting) (citations omitted) (quoting id. at 69 (plurality opinion) and Verbatim Report of Proceedings at 214, In re Troxel (Wash. Super. Ct. Dec. I4, 1994) (No. 93-3-00650-7)).

243. Id. at 62 (plurality opinion) (quoting Findings of Fact and Conclusions of Law Dated and Filed January 3, 1996, In re Troxel (Wash. Super. Ct. Dec. 14, 1994) (No. 93-300650-7), reprinted in Joint App. at 68a, 70a, Troxel v. Granville, 530 U.S. 57 (2000) (No. 99-138)).

244. Id. at $69-73$ (plurality opinion).

245. Id. at 75 (plurality opinion).

246. Id. at 72 (plurality opinion) ("[T]his case involves nothing more than a simple disagreement between the Washington Superior Court and Granville concerning her children's best interests."). 
of the Troxel grandparents in order to criticize the state for preferring grandparents to parents and the court for allowing the state to interfere with the relationships between a fit mother and her children. "The problem," Justice O'Connor explained, "is not that the Washington Superior Court intervened, but that when it did so, it gave no special weight at all to Granville's determination of her daughters' best interests. More importantly, it appears that the Superior Court applied exactly the opposite presumption."247 Justice O'Connor then pinpointed aspects of Judge Rickert's oral decision that, taken in isolation, seem insufficient to justify his visitation order, but that actually must be examined in light of a wider view of the trial court's understanding of the law and facts in order to be fairly evaluated. ${ }^{248}$

The preference of the plurality for Tommie Granville over Judge Rickert (and the Troxel grandparents) emerged clearly as the opinion portrayed the parties and their options. In examining Judge Rickert's decision through this dialogue, the Troxel plurality played several roles, acting on the one hand as referee between Tommie Granville's and Judge Rickert's competing visions of the family, and on the other hand not as referee, but as arbiter/judge. ${ }^{249}$ In its posture as referee, the plurality seemed ready, as a social worker presumably would be, to redirect Judge Rickert's attention, and to convince him to acknowledge the perceptivity of Tommie Granville's conclusions about her daughters' welfare. ${ }^{250}$ Here the plurality seemed to assume its role was to mediate and enlighten. But then the plurality abandoned the role of mediator and (as judge) deemed the entire game to have been misguided. ${ }^{251}$ The text is worth examining in greater detail because it illustrates many of the confusions that underlie Americans' responses to family matters.

\section{Id. at 69 (plurality opinion).}

248. Justice Stevens made a similar point in dissent. He explained:

The task of reviewing a trial court's application of a state statute to the particular facts of a case is one that should be performed in the first instance by the state appellate courts. In this case, because of their views of the Federal Constitution, the Washington state appeals courts have yet to decide whether the trial court's findings were adequate under the statute. Any as-applied critique of the trial court's judgment that this Court might offer could only be based upon a guess about the state courts' application of that State's statute, and an independent assessment of the facts in this case-both judgments that we are ill-suited and illadvised to make.

Id. at 81-82 (Stevens, J., dissenting) (footnotes omitted).

249. See id. at 69-73 (plurality opinion).

250. See id. (plurality opinion) (detailing Judge Rickert's view of the Troxel girls' welfare and comparing it with Tommie Granville's view).

251. See id. at 71-73 (plurality opinion) (comparing Tommie Granville's and Judge Rickert's views of the children's welfare in detail and then concluding that Judge Rickert's view was precluded by the Due Process Clause, which "does not permit a State to infringe on the fundamental right of parents to make child rearing decisions simply because a state judge believes a 'better' decision could be made"). 
Granville was characterized as a fit mother,252 while the judge (and by implication the grandparents) were presented as shallow and ill-considered. The plurality quoted the trial court:

The burden is to show that it is in the best interest of the children to have some visitation and some quality time with their grandparents. I think in most situations a commonsensical approach [is that] it is normally in the best interest of the children to spend quality time with the grandparent, unless ... the grandparents ['] . . . lifestyles are going to impact adversely upon the children. That certainly isn't the case here from what I can tell. 253

The plurality recounted Judge Rickert's conclusion: "I think [visitation with the Troxels] would be in the best interest of the children and I haven't been shown it is not in [the] best interest of the children.' "254 The plurality further presented Judge Rickert's reasoning:

[T] he [Washington] Superior Court made only two formal findings in support of its visitation order. First, the Troxels "are part of a large, central, loving family, all located in this area, and the [Troxels] can provide opportunities for the children in the areas of cousins and music." Second, "the children would be benefitted from spending quality time with the [Troxels], provided that that time is balanced with time with the childrens' [sic] nuclear family." . . . The [Washington] Superior Court's announced reason for ordering one week of visitation in the summer demonstrates our conclusion well: "I look back on some personal experiences .... We always spen[t] as kids a week with one set of grandparents and another set of grandparents, [and] it happened to work out in our family that [it] turned out to be an enjoyable experience. Maybe that can, in this family, if that is how it works out."255

Against this corrective model of family as extended kin-favored by the Troxels, Judge Rickert, and Justices Stevens and Kennedy ${ }^{256}$ - the

252. Id. at $68-69$ (plurality opinion).

253. Id. at 69 (plurality opinion) (first alteration in original) (quoting Verbatim Report of Proceedings at 213, In re Troxel (Wash. Super. Ct. Dec. 14, 1994) (No. 93-300650-7)).

254. 1d. (plurality opinion) (alterations in original) (quoting Verbatim Report of Proceedings at 213, In re Troxel (Wash. Super. Ct. Dec. 14, 1994) (No. 93-3-00650-7)).

255. Id. at 72 (plurality opinion) (citations omitted) (alterations in original) (quoting, with respect to the first and second quotes, Findings of Fact and Conclusions of Law, Dated and Filed January 3, 1996, In re visitation of Troxel (Wash. Super. Ct. Dec. 14, 19994) (No. 93-3-00650-7), reprinted in Joint App. at 68a, 70a, Troxel v. Granville, 530 U.S. 57 (2000) (No. 99-138) and, with respect to the third quote, Verbatim Report of Proceedings at 220-21, In re Troxel (Wash. Super. Ct., Dec. 14, 1994) (No. 93-3-00650-7)).

256. Both Justice Kennedy and Justice Stevens voiced an understanding of family similar in several important respects to that preferred by the Troxels and by Judge Rickert. Justice Kennedy criticized the plurality for premising its understanding of parental authority (as a constitutional matter) on inaccurate assumptions about the social parameters of American family life: 
plurality posed another corrective model, the one it preferred-that of the traditional nuclear family. That model closely parallels the model underlying Meyer and Pierce, both decided in the 1920 s and invoked by the plurality. ${ }^{257}$ A popular understanding of those cases has reinterpreted them to stand primarily for liberty and choice within the domestic area. ${ }^{258}$ Each case provided parents with the right, as against the state, to make a set of educational decisions for their children. ${ }^{259}$ However, the vision of family underlying each decision has been widely forgotten or ignored. In fact, both cases assumed a "property-based notion of the private child" 260 that reflected an ideology that prized "private ownership, hierarchical structures, and individualist values against claims of collective governance."261

The invocation of Meyer and Pierce by the plurality in Troxel serves two contradictory ends. 1t reflects the law's commitment to protect familial relationships from excessive state intervention that is presumed by revisionists to be the popular conception of Justice McReynolds's decisions in those cases. ${ }^{262}$ But the invocation also reflects a vision of family that val-

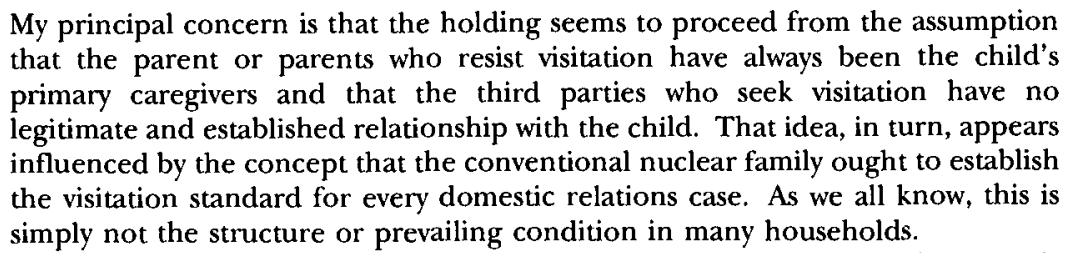

1d. at 98 (Kennedy, J., dissenting) (citing Moore v. City of E. Cleveland, 431 U.S. 494 (1977)).

Justice Stevens voiced a similar concern in his dissenting opinion: "The almost infinite variety of family relationships that pervade our ever-changing society strongly counsel[s] against the creation by this Court of a constitutional rule that treats a biological parent's liberty interest in the care and supervision of her child as an isolated right that may be exercised arbitrarily." Id. at 90 (Stevens, J., dissenting).

257. See id. at 65 (plurality opinion).

258. In a wonderful and provocative analysis of both Meyer and Pierce in their historic contexts, Barbara Bennett Woodhouse describes contemporary invocations of each case to reflect broad claims for "a liberal and libertarian spirit," and for "pluralism, family autonomy, and the right 'to heed the music of different drummers." Woodhouse, supra note 233, at 997 (quoting Laurence H. Tribe, American Constitutional Law $\$ 15-6$, at 1319 (2d ed. 1988)).

259. Pierce v. Society of Sisters, 268 U.S. 510, 536 (1925) (invalidating Oregon statute that required children to attend public schools); Meyer v. Nebraska, 262 U.S. 390, 403 (1923) (invalidating state statute precluding teaching elementary school children in foreign language).

260. Woodhouse, supra note 233 , at 1002 . This notion, in Woodhouse's view, "cuts off a more fruitful consideration of the rights of all children to safety, nurture, and stability." Id.

261. Id. at 1037.

262. Woodhouse describes this revisionist presumption:

We like to think of [Meyer and Pierce] as the good personal liberty gold of substantive due process left when the evil dross of economic due process was purged. They are the foundation cases for an entire constitutional theory of family. In spite of the fact that the several lines of precedent they generated cover 
ues hierarchy and the "isolation" of the child from a community of extended kin. ${ }^{263}$

In a complicated strategy, ${ }^{264}$ presumably less than fully self-conscious, the Troxel plurality thus justified its preferred vision of family (that reflected in the original message of Meyer and Pierce) by invoking Meyer and Pierce, as those precedents are almost always invoked by contemporary jurists, to justify protecting family relationships from excessive state intervention. In short, the plurality relied on Meyer and Pierce to paint the state court's decision in Troxel as an inexcusable intrusion into Tommie Granville's relationship with her daughters. But the plurality appears never to have considered that its decision was also an intrusion (from some perspectives, similarly inexcusable) into Natalie and Isabelle's family of extended kin. ${ }^{265}$

In contrast, Judge Rickert's decision for the trial court is premised upon a different model of family-one representing a vision of family much like that detailed and praised by the Court almost a quarter century

the most controversial territory of our times, the Court seems to accept Meyer and

Pierce themselves as pure and uncomplicated, virtual products of an immaculate conception.

Id. at 997-98. Woodhouse provides a compelling, revisionist interpretation of Meyer and Pierce. She demonstrates that the two cases, generally viewed as liberal icons that protected intellectual liberty primarily and family autonomy secondarily, id. at 1112, should instead be seen as having "constitutionalized a narrow, tradition-bound vision of the child as essentially private property," id. at 997 , and "announced a dangerous form of liberty, the right to control another human being," id. at 1001.

263. See id. at 1000-01.

264. The Court's approach is complicated because it simultaneously reflects deeply contradictory readings of Meyer and Pierce. In one reading-probably close to that intended by Justice McReynolds, who authored both decisions-the decisions grant parents enormous authority to raise their children and presume children's non-autonomy because children are viewed, in both decisions, as objectified parental property. See id. at 999-1001. In a second reading of Meyer and Pierce-one generally assumed by contemporary jurists and commentators-Justice McReynolds's decisions represent a modern attempt to protect family privacy, including parental rights, from state regulation. See id. at 1000-01. This reading focuses on the Court's protection of parental autonomy vis-à-vis the state. Justice O'Connor's use of Meyer and Pierce harmonizes with the likely view of Justice McReynolds in presuming a traditional (hierarchical, holistic) understanding of families. Yet, almost inevitably, because Meyer and Pierce have been so widely reinterpreted, Justice O'Connor's reading suggests a liberal approach to family, aimed at protecting privacy. Id; see also supra note 262 and accompanying text (considering Barbara Woodhouse's revisionist interpretation of Meyer and Pierce).

265. In some part, the plurality's strategy succeeded because Judge Rickert did not provide a careful analysis of the competing claims and interests presented by Tommie Granville, Natalie and 1sabelle Troxel, and Jenifer and Gary Troxel. Judge Rickert's original decision in the case was rendered orally. Troxel v. Granville, 530 U.S. 57, 61 (2000) (plurality opinion). And his "findings of fact and conclusions of law," drafted in response to the remand order of the state's intermediate appellate court, id. (plurality opinion), appears to have been drafted quickly to accomplish the task assigned, without any consideration that the case-so similar to many others Judge Rickert certainly entertained every week-would be reviewed by the country's highest court. 
earlier in Moore v. City of East Cleveland. ${ }^{266}$ His vision of family includes an extended collection of kin and provides for the involvement of grandparents, cousins, aunts, and uncles in children's lives. ${ }^{267}$ Such family networks, as portrayed by Judge Rickert, serve children's welfare by enriching their lives with the love and varied talents that parents alone cannot always bestow upon their children. ${ }^{268}$ Thus, Judge Rickert's justification for his decision-which appears irresponsible when a nuclear model of family is assumed-appears more reasonable when assessed in light of the model of family upon which he, in fact, relied. ${ }^{269}$

Notwithstanding the justifications for alternative models of family that may have seemed apparent to Judge Rickert, the plurality ostensibly safeguarded the nuclear model of family rather than other models by arguing that the Constitution protects a parent's right to socialize children, but not a grandparent's right to do the same. That justification was disingenuous and has been since the Court's decisions three-quarters of a century ago in Meyer and Pierce. Each of the "traditional" models of family (the nuclear model and the extended-kin model) could be understoodthough in quite different ways-as an antidote to the growing social and legal tendency to recognize family members as autonomous individuals,

266. See 431 U.S. 494, 504-06 (1977) (plurality opinion) (invalidating city housing ordinance that defined "family" narrowly).

267. See Troxel, 530 U.S. at 61-62, 69-72 (plurality opinion).

268. See id. at 72 (plurality opinion).

269. Similarly, in presenting their case to the Supreme Court, Jenifer and Gary Troxel stressed the advantages for both children and adults of large networks of loving kin. Troxel Brief for Petitioners, supra note 173, at 39-46. Disputing the validity of the state supreme court's decision, the Troxels' brief to the Court asserted:

The Washington court's analysis of the familial relationships at issue in this case focused exclusively on the parent-child relation between [Tommie Granville] and her daughters. In common parlance, however, petitioners and their granddaughters would also be described as being part of the same "family," albeit in a somewhat broader sense. Grandparent visitation statutes are grounded on a recognition that grandparents are part of a child's family.

ld. at 39-40. Contending that the law should protect relationships between grandparents and grandchildren, the Troxels invoked Moore as well as a set of state court decisions. Id. at 40 \& n.55 (citing Moore, 431 U.S. at 504-05; Sightes v. Barker, 684 N.E.2d 224, 230 (Ind. Ct. App. 1997) ("Grandparents are members of the extended family whom society recognizes as playing an important role in the lives of their grandchildren ...."); Herndon v. Tuhey, 857 S.W.2d 203, 209 (Mo. 1993) (“[G]randparents are members of the extended family whom society has traditionally recognized as playing an important role in the raising of their grandchildren."); id. at 41 \& n.57 (citing In re Lippincott, 124 A. 532, 533 (N.J. Ch. 1924) in support of proposition that "the opportunity for developing a relationship with a grandparent may have passed" if relationship is not cemented during child's early years). The Troxels argned that the vision of family as a collection of kin underlying these decisions provided a salutary response to the hurtful consequences for children of " the disintegration of the nuclear family.'" Id. at 43 (quoting Campbell v. Camphell, 896 P.2d 635, 643 (Utah Ct. App. 1993)). They then cited Campbell in support of their assertion that state legislatures should be applauded for countering family disintegration by "attempt[ing] to strengthen intergenerational ties as an alternative or supplementary source of family support for children." ld. (quoting Campbell, 896 P.2d at 643). 
free to define their roles and relationships as they choose. Indeed, the extended-kin model, actualized in nonparental visitation statutes, was proposed by many as a "traditional" response to the erosion of the nuclear family and the recent trend in the law of supporting adults' autonomous choices within families. ${ }^{270}$ Moreover, even adherents of modernity, who prize autonomous individuality for adults in domestic contexts, often hesitate to apply a comparable understanding of personhood to children or to regulate the parent-child relationship as if each party were an autonomous individual, free to negotiate the terms of relationship. ${ }^{271}$ Thus, insofar as children's interests are concerned, the search for alternative understandings of family has become a central component of the wider social debate about family. ${ }^{272}$

\section{Misuse of Precedent}

Finally, the fragility of Troxel is suggested by the plurality's misuse of precedent. Justice O'Connor set the stage for her comparison of a nuclear model of family with an extended-kin model, and for her ultimate choice in favor of the former, by invoking a set of substantive due process precedents presumed to protect the "fundamental right" of parents "to make decisions concerning the care, custody, and control of their children." 273 Though she listed nine cases, ${ }^{274}$ she did so without analysis, commenting neither on the cases nor on their relevance to Troxel. In lieu of analysis, the plurality quoted a sentence or two from each case. The recitation is familiar and formulaic. ${ }^{275}$ In Troxel, the recitation was of-

270. The American Association of Retired People and other amici argued in their Troxel briefs that nonparental (and especially grandparent) visitation statutes represented

a national response to increasing rates of parental drug use, teen pregnancy, divorce, single-parent households, crime, and child abuse. The legislative history of grandparent visitation statutes around the country is replete with examples of legislators and their constituents testifying about the need for such statutes to promote the well being of children who are facing challenges unprecedented in this nation's history. Troxel AARP Amicus Brief, supra note 164, at 2-3.

271. See Whitehead, supra note 4 , at 142-51 (describing contemporary ideology of family that presumes divorce need not harm children if emotional bonds are encouraged between children and various adults, including grandparents, teachers, and "fictive kin").

272. See id, at 147-48 ("In the world of family magazines the idea that a family is defined by its affections rather than by its structure has become widely diffused.").

273. Troxel v. Granville, 530 U.S. 57, 66 (2000) (plurality opinion).

274. Id, at 65-66. These cases include: Meyer v. Nebraska, 262 U.S. 390 (1923); Pierce v. Society of Sisters, 268 U.S. 510 (1925); Prince v. Massachusetts, 321 U.S. 158 (1944); Stanley v. 1llinois, 405 U.S. 645 (1972); Wisconsin v. Yoder, 406 U.S. 205 (1972); Quilloin v. Walcott, 434 U.S. 246 (1978); Parham v. J. R., 442 U.S. 584 (1979); Santosky v. Kramer, 455 U.S. 745 (1982); and Washington v. Glucksberg, 521 U.S. 702 (1997). Glucksberg did not directly concern a dispute involving the scope or meaning of parental authority or of childhood; rather it involved a Washington state statute that made physician-assisted suicide illegal. Glucksberg, 521 U.S. at 707.

275. Justice Souter, concurring in Troxel, referred to a similar set of cases. He noted that the Court has "long recognized that a parent's interests in the nurture, upbringing, companionship, care, and custody of children are generally protected by the Due Process 
fered as the key that resolved the central questions at stake, but, in effect, it substituted enumeration for analysis. It thus displaced most of the difficult questions raised by the case ${ }^{276}$ with the assertion that the Court knew, because it had long known, how best to define families and to protect children in families.

Further, at a more concrete level, it is not clear that the plurality even demonstrated that the precedents cited are determinative of the proper outcome in Troxel. Indeed, Justice Scalia asserted, in his dissenting opinion, that most of the precedents on which the plurality relied are only peripherally relevant to the conclusion that parents enjoy a substantive right to control their children's upbringing. ${ }^{277}$ Additionally, the plurality failed to mention a set of cases, beginning with Bellotti v. Baird (Bellotti II), ${ }^{278}$ that speaks directly to the character of the parent-child relationship and suggests presumptions about children and the parentchild relationship that are at odds with the presumptions undergirding the cases the plurality invoked. ${ }^{279}$ In short, the precedents on which Jus-

Clause of the Fourteenth Amendment." 530 U.S. at 77 (Souter, J., concurring) (citing Meyer, 262 U.S. at 399, 401; Pierce, 268 U.S. at 535; Stanley, 405 U.S. at 651; Yoder, 406 U.S. at 232; Quilloin, 434 U.S. at 255; Parham, 442 U.S. at 602; Santosky, 455 U.S. at 753; Glucksberg, 521 U.S. at 720 ).

276. Among these are questions about the status of and appropriate role for children in families increasingly shaped by adults' individualist choices; the consequences of insisting upon traditional understandings of the parent-child relationship in a time when we have largely abandoned traditional forms of family life; and the scope and implications of childhood itself.

277. Troxel, 530 U.S. at 92 (Scalia, J., dissenting). Justice Scalia argues: "Only three holdings of this Court rest in whole or in part upon a substantive constitutional right of parents to direct the upbringing of their children-two of them from an era rich in substantive due process holdings that have since been repudiated." ld. (Scalia, J., dissenting) (citing Meyer, 262 U.S. at 399, 401; Pierce, 268 U.S. at 534-35; and Yoder, 406 U.S. at 232-33). Justice Scalia concludes that those holdings had not induced substantial reliance and that: "The sheer diversity of today's opinions persuades me that the theory of unenumerated parental rights underlying these three cases has small claim to stare decisis protection." Id. (Scalia, J., dissenting).

278. 443 U.S. 622, 651 (1979) (declaring Massachusetts parental consent requirement for abortions by minors unconstitutional for failure to provide minors with judicial bypass option). Bellotti $I I$ and the cases that followed it involving the abortion right of female minors do not define girls as autonomous but do allow girls the choice of displacing parental authority by instead turning to the judiciary for permission to abort a pregnancy. See, e.g., Planned Parenthood v. Casey, 505 U.S. 833, 899 (1992) (upholding Pennsylvania statute requiring minor girl seeking abortion to obtain "informed consent" of one parent or to seek judicial bypass); Hodgson v. Minnesota, 497 U.S. 417, 454-55 (1990) (invalidating Minnesota statute's two-parent consent requirement and upholding same requirement with a bypass option); Ohio v. Akron Ctr. for Reprod. Health (Akron II), 497 U.S. 502, 519-20 (1990) (upholding state's one-parent notification statute with judicial bypass option).

279. Bellotti $I I$ and subsequent decisions about the limits of a minor's right to terminate a pregnancy locate at least one context within which the state can legitimately displace parents in directing a child's upbringing. See supra note 278 (noting cases involving right vel non of minor girl to abortion). 
tice O'Connor relied in Troxel ${ }^{280}$ can be, and have been, variously interpreted; they are often self-contradictory; and, as a group, they rest on disputed jurisprudential ground. Yet these precedents constitute the plurality's chief arguments for invalidating the reasoning of the state trial court in the case.

\section{Implications for Post-Troxel Decisions in Cases Involving Nonparental Visitation Statutes}

Troxel represents the product of a Court as confused as the society it serves about both the contours of "family," and the implications for children of contemporary understandings of adults within families as autonomous individuals. The tone of Justice O'Connor's plurality opinion sides firmly with an old-fashioned understanding of family, but the message of the opinion is garbled because the plurality's conception of family is largely unrelated to actual families-especially those families, such as the Troxel-Wynn family, affected by death or divorce, and engaged in painful, internal disputes about children. In short, the insistence that families be governed through reference to a conception of family not reflected in the reality of modern family life renders the Court's judgments about family matters increasingly out of step with life beyond the courtroom.

The reasoning of the plurality in Troxel depends on a set of traditional, and increasingly problematic, presumptions about parents and children. For example, the presumption that fit parents-even parents experiencing great tensions and instability in their domestic lives-serve their children's interests better than any one else, ${ }^{281}$ which was invoked

280. See 530 U.S. at 65-66 (plurality opinion).

281. The presumption was expressly stated by the Supreme Court in Parham v. J.R., 442 U.S. 584, 602 (1979). Chief Justice Burger, relying on Blackstone to support his understanding of family, delineated and relied on the presumption in a case that involved a class action by children whose parents had arranged their "voluntary" institutionalizations in Georgia mental hospitals. Id. at 602 ("[H]istorically it has been recognized that natural bonds of affection lead parents to act in the best interests of their children.") (citing 1 William Blackstone, Commentaries *447; 2 James Kent, Commentaries on American Law *190). The presumption seems especially troubling in light of the facts of Parham itself which, as portrayed by Justice Brennan's dissent, involved a "break in family autonomy" that "actually resulted in the parents' decision to surrender custody of their child to a state mental institution." Id. at 631 (Brennan, J., concurring in part and dissenting in part). The presumption seems preposterous when applied, as it was by the Court in Parham, to the state in its role as guardian for children who had become "wards of the state." Id. at 618 . The Court explained:

Contrary to the suggestion of the dissent, however, we cannot assume that when the State of Georgia has custody of a child it acts so differently from a natural parent in seeking medical assistance for the child. No one has questioned the validity of the statutory presumption that the State acts in the child's best interest. Nor could such a challenge be mounted on the record before us.

Id. The Court further opined:

Indeed, if anything, the decision with regard to wards of the State may well be even more reasonable in light of the extensive written records that are compiled about each child while in the State custody. In J. R.'s case, the admitting 
in Troxel ${ }^{282}$ (as it has been in other Supreme Court and lower federal court decisions involving children ${ }^{283}$ ), reflects nostalgia for a safer, more stable past. ${ }^{284}$ Yet, the plurality in Troxel-more aware or, perhaps, simply more desperate than the Court was in 1979 when it voiced the presumption in Parham v.J.R.285 - recognized that the conception of family it preferred (and then proceeded to assume in rendering its decision) is widely challenged by alternative understandings of family and, more concretely, by "demographic changes ... [that] make it difficult to speak of an average American family." 286 Thus, in some significant part, the plurality decision represents a yearning for the resurrection of a disintegrating social universe. And so, it is not surprising that Troxel, read as a set of six responses to disputes about nonparental visitation, reveals disagreement and confusion among the Justices about the scope of the domestic arena, and about the extent to which the law can or should intervene as

physician had a complete social and medical history of the child before even beginning the diagnosis. ...

Since the state agency having custody and control of the child in loco parentis has a duty to consider the best interests of the child with respect to a decision on commitment to a mental hospital, the State may constitutionally allow that custodial agency to speak for the child.

Id. at $618-19$.

The Court's attempts to qualify the application of the presumption to the state hardly weaken the sense that the Court lost its collective sense in this case. The Court asserted by way of qualification:

It is possible that the procedures required in reviewing a ward's need for continuing care should be different from those used to review the need of a child with natural parents. As we have suggested earlier, the issue of what process is due to justify continuing a voluntary commitment must be considered by the District Court on remand.

Id. at 619 .

282. See 530 U.S. at 69 (plurality opinion) (noting the "traditional presumption that a fit parent will act in the best interest of his or her child").

283. See, e.g., Hodgson v. Minnesota, 497 U.S. 417, 484 (1990) (Kennedy, J., concurring in part and dissenting in part) ("A State may seek to protect and facilitate the parent-child bond on the assumption that parents will act in their child's best interests."); Ohio v. Akron Ctr. for Reprod. Health (Akron II), 497 U.S. 502, 523 (1990) (noting Parham's "presumption that parents act in the best interests of their child" (quoting Parham, 442 U.S. at 610)); H.L. v. Matheson, 450 U.S. 398, 423 \& n.1 (1981) (Stevens, J., concurring) ("A state legislature may conclude that most parents will be primarily interested in the welfare of their children.' (citing Parham and quoting Planned Parenthood v. Danforth, 428 U.S. 52, 103-04 (1976) (Stevens, J., concurring.))); Halderman v. Pennhurst State Sch. \& Hosp. 707 F.2d 702, 708 (3d Cir. 1993) (invoking presumption as described in Parham); Colon v. Collazo, 729 F.2d 32, 34 (lst Cir. 1984) (same); In re Baby K, 832 F. Supp. 1022, 1030 (E.D. Va. 1993) (same), aff'd, 16 F.3d 590 (4th Cir. 1994); Heichelbech v. Evans, 798 F. Supp. 708, 713-14 (M.D. Ga. 1992) (discussing Parham but finding it to be inapplicable).

284. See Coontz, Never Were, supra note 5, at 1-2 (arguing that even that past was largely constructed after-the-fact as a product of nostalgia).

285. See supra note 281 (describing and considering Parham).

286. Troxel, 530 U.S. at 63 (plurality opinion). 
moral arbiter - a task that once belonged to priests, educators, poets, and leaders of community institutions.

As a consequence, Troxel not only obfuscates the ideological context within which American families are being redesigned, but also fails to provide legislators and lower court judges with a clear set of guidelines for composing and interpreting nonparental visitation statutes. Thus, the decision leaves lower courts with wide interpretive flexibility and legislators with little direction. 1ndeed, the Court expressly refrained from "defin[ing] ... the precise scope of the parental due process right in the visitation context," 287 and reached no conclusion about whether nonparental visitation statutes must premise visitation on a showing of harm or potential harm to the child if visitation were prohibited. ${ }^{288}$

For instance, even the analysis in Justice O'Connor's opinion adds to the confusion emanating from Troxel. O'Connor claimed to have rested her decision "on the sweeping breadth" of Washington's nonparental visitation statute and its application in the case of the Troxels. ${ }^{289}$ Yet, the case itself involved a petition for visitation by people who would enjoy that right under the most restrictive nonparental visitation statutes. Not only were the petitioners the grandparents of the children involved, the children they were seeking to visit were those of a deceased son. ${ }^{290}$ Belying O'Connor's assertion about the breadth of the statute's application in Troxel, in reality the narrowest nonparental visitation statutes limit potential petitioners to grandparents in situations involving parental death, divorce, or separation. ${ }^{291}$

The multiplicity of opinions, the absence of a majority position, and O'Connor's confusing characterization of the statute give lower courts resolving nonparental visitation disputes even greater latitude in responding to disputes about nonparental visitation. It is thus not surprising that post-Troxel judicial decisions about nonparental visitation are almost as various as they were before Troxel. ${ }^{292}$ Many state court decisions about

287. Id. at 73 (plurality opinion).

288. Id. (plurality opinion).

289. Id. (plurality opinion).

290. Id. at 60 (plurality opinion).

291. See, e.g., Ark. Code Ann. \$9-13-103(a)(1) (Michie 1998) (providing for grandparent visitation petitions if child was born out of wedlock or child is not in custody of parent); Ind. Code Ann. § 31-17-5-1 (a) (1997) (allowing grandparent visitation petitions if parent of child is dead, parents' marriage was dissolved by state, or child was born outside marriage); Neb. Rev. Stat. \$ 43-1802(1) (1998) (allowing grandparent visitation petitions with minor grandchild if child's parent or parents are dead, parents are divorced, or parents never married but paternity was established legally).

292. Before Troxel there was wide disagreement among state courts about nonparental visitation questions. See John DeWitt Gregory, Blood Ties: A Rationale for Child Visitation by Legal Strangers, 55 Wash. \& Lee L. Rev. 351, 388-97 (1998) (noting variety of conclusions in state high court decisions about nonparental visitation before (roxel). In 1996, Joan Bohl, surveying "selected grandparent visitation cases," concluded: "Challenges brought in different jurisdictions to the constitutionality of open-ended grandparent visitation statutes have been answered with wildly inconsistent judicial pronouncements." 
nonparental visitation rendered after June 2000 have invoked Troxel and presumed (as, in theory, they must) to follow its rule. ${ }^{293}$ But there is no agreement-as there cannot be-about the dictates of that rule. And thus the potential uses of Troxel are almost as diverse as the intuitions and insights of the many judges who have entertained the wide variety of narratives about nonparental visitation that have arrived in court since June 2000.

One set of these narratives has concerned grandparent visitation. Some state courts considering this set of narratives have invalidated nonparental visitation statutes; most have not. A second set of narratives about nonparental visitation has arisen from petitions by third parties, not related to the children in question through marriage or birth, but intimately involved, at least for some time, in raising them. In these cases, a number of state courts have displaced the implications of Justice O'Connor's cry for the resurrection of tradition by framing the petitioners as "de facto" or "psychological" parents. ${ }^{294}$

Troxel has not significantly altered lower courts' responses to nonparental visitation disputes and the statutes at issue in those disputes. ${ }^{295}$ Now, however, lower courts are beholden to a hazy rule, imposed by a confused and divided Court. In effect, Troxel has become a deus ex machina for lower court judges who disapprove of court ordered nonparental visitation, and an easily surmounted hurdle for those who approve of such visitation. Thus, it obfuscates the social and legal parameters of American family life.

This Part first considers the effect of Troxel on nonparental visitation decisions by reviewing post-Troxel decisions in New York and California.

Joan C. Bohl, The "Unprecedented Intrusion": A Survey and Analysis of Selected Grandparent Visitation Cases, 49 Okla. L. Rev. 29, 31 (1996). Bohl illustrated that conclusion by comparing King v. King, 828 S.W.2d 630 (Ky. 1992), decided by Kentucky's highest court in 1992, and Hawk v. Hawk, 855 S.W.2d 573 (Tenn. I993), decided by Tennessee's highest court a year later. The facts of the two cases are similar. Each involved a grandparent petition for the right to visit with the child of a son and his wife (in each case, the son's wife was also the mother of the child involved). King, 828 S.W.2d at 630-31; Hawk, 855 S.W.2d at 575-76. The relevant statutes were "functionally identical." Bohl, supra, at 32. In Kentucky, five of seven justices found the statute constitutional. King, 828 S.W.2d at 633 . In contrast, Tennessee's supreme court invalidated the statute as "a virtually unprecedented intrusion into . . f family life." Hawk, 855 S.W.2d at 577. Moreover, Bohl describes the two "irreconcilable assessments" of grandparent visitation statutes as representative of "two prototypical judicial responses." Bohl, supra, at 33.

293. See infra Part VI.A-B (discussing visitation cases decided since Troxel).

294. The terms de facto parent, psychological parent, and functional parent may be used interchangeably to refer to someone who is not a child's legal parent (through biology or adoption) but who has served in the parental role for a child by living with the child, bonding with the child, and performing parental tasks. See A.F. v. D.L.P., 771 A.2d 692, 697 \& n.2 (N.J. Super. Ct. App. Div. 2001) (citing V.C. v. M.J.B., 748 A.2d 539, 546 n.3 (N.J. 2000)).

295. See infra Part VI.A. (demonstrating that, even in the wake of Troxel, lower courts have been able to reach contrary conclusions about the legality of nonparental visitation statutes-thus suggesting the limited impact Troxel has had). 
This review reveals a variety of conflicting responses within each state. This Part then considers cases from other states that, by relying on the notion of "de facto" parentage to evade Troxel, further demonstrate the elasticity of Troxel's standard.

\section{A. Grandparent Visitation ${ }^{296}$}

A review of court responses to grandparent visitation petitions since Troxel reveals that, even within the same state, lower courts have reached contrary conclusions about the continued constitutionality of state nonparental visitation statutes. For instance, in both New York and California, ${ }^{297}$ courts have not responded uniformly to cases involving grandparent visitation petitions.

1. New York Cases. - In New York, four reported post-Troxel decisions considered the constitutionality of the state's grandparent visitation statute. ${ }^{298}$ The statute, narrower than that at stake in Troxel, allows grandparents to petition for visitation in two situations: where either one or both of the child's parents are dead, or where grandparents can demonstrate that "equity would see fit to intervene." ${ }^{299}$ ln one case, a New York court found the state's statute unconstitutional under Troxel. ${ }^{300}$ ln the other three, however, the statute was upheld. Each court focused on some dimension of Troxel that served its purpose, but none seemed compelled by Troxel to reach its decision.

In the first of these decisions, Smolen $v$. Smolen, Judge Klim, for New York's family court, denied a fit mother's ${ }^{301}$ request to dismiss the visitation petition of her parents, Frank and Cynthia Smolen, requesting a con-

296. The following discussion considers only reported decisions of New York and California state courts involving grandparent visitation petitions. It is likely that other forms of petitions have been entertained or decided in both states.

297. A comprehensive review of relevant post-Troxel decisions within state and lower federal courts would be instructive with regard to the uses and perceived implications of Troxel. That review is beyond the scope of this Article.

298. Hertz v. Hertz, 717 N.Y.S.2d 497 (Sup. Ct. 2000); Davis v. Davis, 725 N.Y.S.2d 812 (Fam. Ct. 2001); Fitzpatrick v. Youngs, 717 N.Y.S.2d 503 (Fam. Ct. 2000); Smolen v. Smolen, 7I3 N.Y.S.2d 903 (Fam. Ct. 2000).

A fifth decision involved a petition for visitation by the biological mother of an adopted child. Chaya S. v. Frederick Herbert L., 725 N.Y.S.2d 576, 576 (App. Div. 200I). The court denied the petition and deemed Troxel irrelevant because the best interests of the fourteen-year old child were deemed best served by denying the request of the biological mother. Id. Finally, a New York appellate court affirmed a lower court order denying visitation to the grandmother of an infant in the custody of an aunt and uncle (respondents in the case) pursuant to a custody arrangement agreed to by the infant's mother. Lawrence v. Lawrence, 7I3 N.Y.S.2d 4I8, 4 I9 (App. Div. 2000).

299. N.Y. Dom. Rel. Law $\$ 72$ (McKinney 1999).

300. Hertz, $7 \mathrm{I} 7$ N.Y.S.2d at 500.

30I. Judge Klim noted the absence of allegations as to the mother's unfitness. Smolen, 713 N.Y.S.2d at 908. 
tinued relationship with their granddaughter. ${ }^{302}$ Noting that Troxel did not require a showing of harm in cases such as Smolen, Judge Klim concluded that New York's nonparental visitation statute was not invalidated by Troxel. ${ }^{303}$ Supporting this conclusion, he further explained that New York courts "generally . . . interpreted" the state's visitation statute so as "to require substantial deference to the authority of parents." 304

In contrast, the next post-Troxel decision in New York about grandparent visitation, Hertz $v$. Hertz, relied on Troxel to invalidate the state's visitation law. ${ }^{305}$ The case involved a grandfather's petition to visit with fifteen grandchildren, the children of his two sons and one daughter. ${ }^{306}$ All three of Sheldon Hertz's children opposed his visitation petition. ${ }^{307}$ Judge Harkavy noted that New York's statute was narrower than that at stake in Troxel, but decided that that did not save the statute since the petitioners in Troxel were also grandparents. ${ }^{308}$ He concluded that New York's statute allowed courts to "substitute [their] own judgment for that of the parent" and, quoting Troxel, further concluded that the law thus "violate[d] the [parents'] due process rigbts, specifically their 'fundamental right [. . . ] to make decisions concerning the care, custody, and control of their children." 309

Then, in Fitzpatrick $v$. Youngs, ${ }^{310}$ a New York family court judge read Troxel to protect New York's grandparent visitation statute from invalidation. Judge McGuire wrote:

This Court views the New York Legislature, and many of the comments in Troxel, as telling parents and grandparents alike that, given the apparent disappearance of the traditional family, children's best interests require the opportunity for participation by siblings and grandparents to be sure that the moral obligations of familial relationships are carried out. What used to be known as the common law is not so common any more. Nonbiologic care givers are assuming previous strictly parental roles more and more frequently. ${ }^{311}$

302. Id. Judge Klim ordered an evidentiary hearing to determine whether the grandparents, as the mother alleged, "engaged in any improper conduct toward [the child]." Id.

303. Id. at $907-08$.

304. Id. at 906.

305. Hertz, 717 N.Y.S.2d at 500.

306. Id. at 498.

307. Id. at 499.

308. Id. at 500 .

309. Id. (quoting Troxel v. Granville, 530 U.S. 57, 66 (2000) (plurality opinion)).

310. 717 N.Y.S.2d 503 (Fam. Ct. 2000).

311. Id. at 506-07. Judge McGuire also noted that " $[t]$ o this point, biologic relationships are mandated by New York, but given the dynamics of present personal relationships, the rules may not be standing on sturdy ground, notwithstanding Troxel." Id. at 507 . 
To support its conclusion, the Fitzpatrick court relied on assertions in Troxel-explicit in the plurality opinion ${ }^{312}$ as well as in the dissents by Justice Stevens ${ }^{313}$ and Justice Kennedy ${ }^{314}$-about the changing shape of the American family. Yet, that conclusion is essentially at odds with the conclusion the Court reached in Troxel. Judge McGuire's decision thus demonstrates that courts can invoke Troxel to support diverse and even contradictory conclusions.

Finally, in Davis v. Davis, ${ }^{315}$ Judge Burns of New York's family court distinguished Troxel despite the similarity of the relevant facts in Davis and Troxel. The Supreme Court, explained Judge Burns, "held that the Washington statute unconstitutionally violated the substantive due process rights of parents to the care, custody, and control of their children." 316 The court failed to differentiate Justice O'Connor's "as applied" decision from a facial invalidation of the Washington statute. But that notwithstanding, the court construed New York's statute so as to render it constitutional. Judge Burns explained: "[C]ourts can remove doubt as to the constitutionality of DRL Sec. 72 [New York's grandparent visitation statute] by requiring that special weight be accorded the preference of parents. If a parent opposes grandparent visits, this preference must be respected absent extraordinary circumstances." 317 The Davis court found such circumstances in the paternal grandmother's "loving and devoted" relationship with her granddaughter ${ }^{318}$ and in particular, in the fact that she "maintain[ed] a link between the child and [her] ... father's side of the family," including "her paternal aunt and cousins," while the child's father was in jail. ${ }^{319}$ Thus the Davis court, which read Troxel broadly to invalidate nonparental visitation statutes, found the facts in Davis exceptional enough to override parental preference even though those facts closely resemble the facts of Troxel itself. ${ }^{320}$ Indeed, the Davis court's invocation of the child's need for continuing relationships with her paternal aunt and cousins parallels the reasoning-virtually mocked by Justice O'Connor-of the trial court judge in Troxel.

312. Troxel, 530 U.S. at 63 (plurality opinion) (referring to difficulty in speaking "of an average American family").

313. Id. at 90 (Stevens, J., dissenting) (referring to " $[t]$ he almost infinite variety of family relationships that pervade our ever-changing society").

314. Id. at 98 (Kennedy, J., dissenting) (noting that "conventional nuclear family" is "simply not the structure or prevailing condition in many households").

315. 725 N.Y.S.2d 812, 815 (Fam. Ct. 2001).

316. Id. at 813 .

317. Id. at 814 .

318. Id.

319. Id. at $815-16$.

320. As in Troxel, visitation was sought by a parent or parents of an unavailahle father (through death in Troxel and through imprisonment in Davis). Troxel v. Granville, 530 U.S. 57, 60 (2000); Dazis, 725 N.Y.S.2d at 812-13. Moreover, as in Troxel, the mother in Davis had married-though her new hushand had not adopted his step-daughter; and as in Troxel the mother did not oppose all visitation between the grandparent and the child. Troxel, 530 U.S. at 60-61; Davis, 725 N.Y.S.2d at 813. 
In New York alone, then, in the year following the Supreme Court's decision in Troxel, courts reached divergent conclusions about the meaning of Troxel. One court invalidated the state's statute as a violation of parents' due process rights; ${ }^{321}$ a second court allowed a grandparent visitation petition to go forward despite Troxel, because state courts generally exhibit "deference to the authority of parents"; ${ }^{322}$ and a third read Troxel to justify the state's statute in light of the "apparent disappearance of the traditional family." ${ }^{293}$ Finally, a fourth court, though purporting to read Troxel strictly, upheld New York's statute by construing it to require deference to parental preferences except in the case of "extraordinary circumstances." 324 This court, however, promptly allowed visitation contrary to parental wishes through reference to facts that hardly seem "extraordinary" and, in truth, closely resemble the facts of Troxel. ${ }^{325}$ Troxel has thus left confusion in its wake.

2. Califormia Cases. - California courts have rendered decisions in three post-Troxel cases involving grandparent petitions for visitation. One court concluded by way of dicta that California's grandparent visitation statute was constitutional under Troxel. ${ }^{326}$ Two other courts found the statute unconstitutional "as applied." ${ }^{27}$

In Lopez v. Martinez, decided in December 2000, the second appellate district terminated court-ordered grandparent visitation pursuant to the state visitation statute, which required such action upon adoption of the child in question by the spouse of the child's parent. ${ }^{328}$ The mother did

321. Hertz v. Hertz, 717 N.Y.S.2d 497, 500 (Sup. Ct. 2000).

322. Smolen v. Smolen, 713 N.Y.S.2d 903, 906 (Fam. Ct. 2000).

323. Fitzpatrick v. Youngs, 717 N.Y.S.2d 503, 507 (Fam. Ct. 2000).

324. Davis, 725 N.Y.S.2d at 814 (citing Bennett v. Jeffreys, 356 N.E.2d 277, 280 (1976), in which New York's highest court allowed a nonparent to be granted custody of a child despite the availability of a parent on the basis of "extraordinary circumstances").

325 . See id. at 814,816 .

326. See Lopez v. Martinez, 102 Cal. Rptr. 2d 71, 77-78 (Ct. App. 2000).

327. Punsly v. Ho, 105 Cal. Rptr. 2d 139, 142, 147 (Ct. App. 2001); Kyle O. v. Donald R., 102 Cal. Rptr. 2d 476, 485-88 (Ct. App. 2000).

328. 102 Cal. Rptr. 2d at 75-76, 78. California statutory law provided that a petition for grandparent visitation:

may not be filed while the natural or adoptive parents are married, unless one or more of the following circumstances exist: (1) The parents are currently living separately and apart on a permanent or indefinite hasis. (2) One of the parents has been ahsent for more than one month without the other spouse knowing the whereabouts of the absent spouse ....

Id. at 73 n.l. (alteration in original) (quoting Cal. Fam. Code $\$ 3104$ (b) (West 1994)).

The court further concluded that the child's adoption by his mother's husband constituted a "change of circumstance" such that the mother was empowered to petition for termination of the grandparents' visitation rights. ld. at 74 .

The Lopez court regretted the consequences of its holding, but found no other option available to it under the relevant state statutory scheme. "We recognize," the judge explained, "this may be one of those relatively rare cases where adherence to a statutory rule may work an injustice in the particular case. Indeed it may prove to be inconsistent with the best interest of this particular child." Id. at 78 . 
not challenge the constitutionality of California's grandparent visitation statute. However, in dicta, the court considered the implications of Troxel for that statute. Judge Johnson read Troxel to have invalidated Washington's comparable statute on the basis of its "breathtakingly broad" scope and its failure to accord adequate deference to parental rights. ${ }^{329}$ On the other hand, the judge explained, California's statute was neither so broad nor so intrusive on parental rights as to require its invalidation. ${ }^{\mathbf{3 3 0}}$

In contrast, two other state appellate courts found the statute unconstitutional "as applied." In Kyle O. v. Donald R., California's third appellate district concluded that the state's grandparent visitation statute was unconstitutional in light of facts similar to those underlying Troxel. ${ }^{331}$ The court read Troxel to require that a nonparental visitation statute be invalidated "as applied" in any case involving a fit parent willing to provide for at least some visitation, and compelled by court order to provide for more extensive visitation than he or she deemed reasonable and sufficient. ${ }^{332}$

329. Id. at 77 .

330. Judge Johnson wrote:

It can hardly be said the California statute at issue in this case comes even close to being so "breathtakingly broad" as to be unconstitutional. On the contrary, it explicitly limits the situations and circumstances in which grandparents can petition for visitation rights. Even when grandparents are statutorily given standing to petition for visitation rights, there is always a rebuttable presumption in favor of the parents when the parents conclude visitation is not in the best interests of the child.

Id.

331. Kyle O., 102 Cal. Rptr. 2d at 477-78.

332. 1d. at 485-86. The court summarized Troxel:

Three factors weighed heavily in the court's analysis: (1) the "sweeping breadth" of the statute that "effectively permits any third party seeking visitation to subject any decision by a parent concerning visitation of the parent's children to statecourt review," (2) the fact there was no allegation or finding that the mother of the children was an unfit parent, and (3) the fact there was no allegation or finding that the mother ever sought to cut off visitation entirely.

Id. at 485 (citations omitted) (quoting Troxel v. Granville, 530 U.S. 57, 66 (2000) (plurality opinion)). The first factor was of no apparent relevance to California's much narrower statute, which only provided for visitation petitions by specific relatives in certain situations:

(a) If either parent of an unemancipated minor child is deceased, the children, sihlings, parents, and grandparents of the deceased parent may be granted reasonable visitation with the child during the child's minority upon a finding that the visitation would be in the best interest of the minor child.

Cal. Fam. Code $\$ 3102$ (West Supp. 2001). The statute further provided:

(b) In granting visitation pursuant to this section to a person other than a grandparent of the child, the court shall consider the amount of personal contact between the person and the child before the application for the visitation order.

(c) This section does not apply if the child has been adopted by a person other than a stepparent or grandparent of the child.

Id. 
Similarly, in Punsly v. Ho, the state's fourth appellate district held California's statute unconstitutional "as applied." 333 Much like Troxel and Kyle O., Punsly involved a visitation petition by grandparents attempting to arrange more extensive visits with the child of their deceased child than the surviving parent of the grandchild desired. ${ }^{334}$ Though the Punsly decision parallels that in Kyle $O$, the Punsly court erroneously read Troxel to have applied strict scrutiny review to Washington's nonparental visitation statute. ${ }^{335}$ Accordingly, the Punsly court found California's statute invalid as applied to the mother because it failed to meet the rigorous demands that form of review imposes. ${ }^{336}$ Moreover, the Punsly court expressly found California's statute overly broad, even though it limited those eligible to petition for visitation to kin of a child's deceased parent. $^{337}$ The court explained:

[S]imilar to the Washington statute, [the relevant California statute] authorizes a court to grant such visitation to a child's grandparents solely upon finding it is in the best interests of the child. 1t is when a court exercises this discretion to substitute its own judgment of a child's best interests for that of a competent custodial parent, that a parent's fundamental rights are threatened. ${ }^{338}$

In sum, state courts in California, like those in New York, interpret Troxel in contradictory ways. One California court distinguished the statute at issue in Troxel and concluded (in dicta) that California's statute was constitutional. ${ }^{339}$ Nonetheless, two other courts analogized the facts of grandparent visitation cases before them to the facts at issue in Troxel and concluded that, as in Troxel, court-ordered visitation constituted an "as applied" violation of the Constitution. ${ }^{340}$ Thus, in California as in New York, Troxel has left ambiguity as its legacy.

\section{B. Visitation by De Facto Parents}

The malleability of Troxel is demonstrated not just by the grandparent visitation cases discussed above, but also by a number of cases in which state courts have at least partially circumvented or have easily dis-

333. 105 Cal. Rptr. 2d 139, 142-47 (Ct. App. 2001).

334. Id. at 141.

335. See id. at 145. While the Troxel plurality did not apply strict scrutiny, Justice Thomas, in his concurrence, argued that it should have: "I would apply strict scrutiny to infringements of fundamental rights. Here, the State of Washington lacks even a legitimate governmental interest-to say nothing of a compelling one-in second-guessing a fit parent's decision regarding visitation with third parties. On this basis, I would affirm the judgment below." Troxel, 530 U.S. at 80 (Thomas, J., concurring).

336. See Punsly, 105 Cal. Rptr. 2d at 145, 147.

337. See id. at $144 \&$ n.6.

338. Id. at 144.

339. Lopez v. Martinez, 102 Cal. Rptr. 2d 71, 77 (Ct. App. 2000).

340. Punsly, 105 Cal. Rptr. 2d at 141; Kyle O. v. Donald R., 102 Cal. Rptr. 2d 476, 478 (Ct. App. 2000). 
tinguished Troxel through reliance on the notion of "de facto" parentage. ${ }^{341}$ Some of these cases have involved grandparent visitation petitions; others have involved petitions by people who were not related to the child, especially former nonmarital cohabitants of a child's legal parent. ${ }^{342}$

In applying the de facto parent notion, some courts have stressed the relationship between the child and the adult involved, and have thus focused primarily on the best interests of the child. Relevant post-Troxel cases of this sort generally have involved visitation petitions by grandparents who acted as parents or even served as exclusive custodians. So, for instance, in Rideout $v$. Riendeau, Maine's highest court upheld the state's grandparent visitation statute. ${ }^{343}$ The court found the statute served "a compelling interest" because, unlike the grandparents in Troxel, the Rideout grandparents had "functioned" as parents. ${ }^{344}$ The court expressly framed its conclusion through reference to the constitutional interests of the children. ${ }^{345}$ The Supreme Court of Georgia similarly distinguished Troxel in two consolidated child custody disputes. ${ }^{346}$ The court upheld the state's "best-interest-of-the-child" custody provision in application to cases involving a custody dispute between a noncustodial parent and a nonparent. ${ }^{347}$

In another set of cases involving application of the notion of de facto parentage, courts stressed-sometimes expressly, sometimes implicitlythe importance of the intentions of, and relationship between, the adults involved, rather than the relationship between the children and the adults seeking visitation. This perspective is illustrated by Rubano $v$. DiCenzo, decided by Rhode Island's highest court a few months after the Supreme Court's decision in Troxel. ${ }^{348}$ Maureen Rubano sought visitation with the biological son of her former lover, Concetta DiCenzo. ${ }^{349}$ Rubano had not adopted the child, but she had lived together with DiCenzo and the boy for four years, serving as a parent to the child. ${ }^{350}$ After the couple separated, Rubano attempted to establish "de facto parental status." 351 1n remanding and directing the lower court to consider

341. See supra note 294 (describing notion of "de facto" parentage).

342. Although, in some part, analysis of these cases falls outside the scope of this Article, it is essential, in the effort to understand Troxel and its socio-legal implications, to note the parallel development within the law of the notion of de facto parentage.

343. 761 A.2d 291, 303 (Me. 2000).

344. 1d. at 301-02.

345. 1d. at 302 (citing Troxel v. Granville, 530 U.S. 57, 86 (2000) (Stevens, J., dissenting)).

346. Clark v. Wade, 544 S.E.2d 99, 106 (Ga. 2001).

347. 1d. at 107. The court interpreted the statute "to mean that the third party must prove by clear and convincing evidence that the child will suffer physical or emotional harm if custody were awarded to the biological parent." Id. at 108.

348. Rubano v. DiCenzo, 759 A.2d 959 (R.I. 2000).

349. 1d. at 962-63.

350. Id. at 961 .

351. Id. at 962. 
Rubano's visitation request, the state supreme court distinguished the issues at stake in Troxel from those at issue in Rubano:

Thus, in contrast to the situation in ... Troxel v. Granville, ... in which the Court invalidated a state statute allowing "any person" to petition for visitation rights "at any time," here we construe [the state statute's] "[a]ny interested party" language much more narrowly, requiring an alleged parent-like relationship with the child before a party who is neither the child's biological parent nor a legal representative of the child can seek relief . . . . ${ }^{352}$

In justifying its conclusion that Rubano had the "requisite parent-like relationship" to seek court-ordered visitation with the child, the court noted three facts. ${ }^{353}$ Rubano's participation with DiCenzo in the decision to conceive a child and the visitation agreement entered into by Rubano and DiCenzo after the couple's relationship ended reflected, in the opinion of the court, the intentions of and relationship between the two adults. ${ }^{354}$ In addition Rubano's role in the child's upbringing reflected her concern for the child's welfare. ${ }^{355}$ In considering the parties' joint decision to have a child, the court noted:

Rubano was "involved with" the child's paternity in that DiCenzo's artificial insemination occurred only pursuant to her "joint decision [with Rubano] to bear a child and to raise said child together." Moreover, Rubano not only allegedly helped to plan and arrange for DiCenzo's conception of the child via artificial insemination from an anonymous donor, she also averred that she was primarily responsible for the financial costs associated with this procedure. On his birth certificate, DiCenzo and Rubano caused the child's last name to be listed as "RubanoDiCenzo" by compounding their surnames. ${ }^{356}$

Further, the court's invocation of the visitation agreement is especially suggestive of a focus on the adults' intentions. In that agreement, DiCenzo granted visitation privileges to Rubano, and Rubano agreed, in exchange, to forfeit her right to claim parentage of the child. ${ }^{357}$ The agreement thus suggests the two women expected to remain together and

352. Id. at 967 (quoting Troxel v. Granville, 530 U.S. 57, 60 (2000) (plurality opinion) (quoting Wash. Rev. Code Ann. $\$ 26.10 .160(3)$ (West 1997))).

353. Id.

354. Id. at 971,976 .

355. Id. at 971.

356. Id.

357. Id. at 967. Similarly, the Rubano court notes that under Pettinato v. Pettinato, Rhode Island family courts have jurisdiction to consider claims of "a person who, though he or she has no biological connection with a child, nonetheless has functioned as a parent in relation to that child and has been held out to the community as the child's parent by the biological parent." Id. at 969 (emphasis added) (invoking Pettinato v. Pettinato, 582 A.2d 909 (R.I. 1990)). 
jointly to be parents of a child to be conceived through the artificial insemination of one of them. ${ }^{358}$

Rhode 1sland's supreme court justified relying on Ruhano's alleged de facto parentage through express reference to U.S. Supreme Court precedents. ${ }^{359}$ ln doing so, the court quoted Justice O'Connor's assertion in Troxel that it has become "difficult to speak of an average American family." "360 The Rhode Island court declared: "[W]e also join with the high Court in recognizing that "persons outside the nuclear family are called upon with increasing frequency to assist in the everyday tasks of child rearing." "361 Invoking the Supreme Court's protection for "freedom of personal choice in matters of . . f family life" 362 as if that protection flowed obviously and smoothly from Troxel, the Rubano court concluded that DiCenzo's parental rights were not unqualified. ${ }^{363}$ Thus, the court balanced DiCenzo's "constitutional liberty interest" as the child's biological mother against the interests of "other parties asserting parental rights" and against the interests of the child. ${ }^{364}$

That Troxel can be invoked to justify both judicial reliance on the notion of de facto parentage (as in Rubano) and the courts' privileging of parents' interests above competing interests (as in Troxel itself) reflects the deep ambivalence and widespread confusion that underlie the Supreme Court's "family" jurisprudence-especially in cases involving children or the parent-child relationship.

\section{Conclusion}

The Court's confusion about family reflects widespread confusion about the erosion of a domestic arena constructed two centuries ago to serve the interests of the Industrial Revolution. ${ }^{365}$ In the second half of the twentieth century, society and the law assimilated new understandings of adults within families, while simultaneously presuming to safeguard traditional understandings of children. Specifically, the law came to recognize adults within families as autonomous individuals, increasingly undifferentiated from actors in the marketplace. However, the liberty extended to adults to make nontraditional family choices has inevitably altered relationships between children and parents. For instance, di-

358. Id. at 961 (describing relationship between the two women vis-à-vis the child).

359. Id. at 972-73.

360. Id. at 974 (quoting Troxel v. Granville, 530 U.S. 57, 63 (2000) (plurality opinion)).

361. Id. at 973 (quoting Troxel, 530 U.S. at 64 (plurality opinion)).

362. 1d. (alteration in original) (quoting Cleveland Bd. of Educ. v. LaFleur, 414 U.S. 632,639 (1974)).

363. ld. at 976 .

364. 1d. at 973 .

365. See supra Part 11.A (describing erosion of "traditional" family and increasing recognition by society and law of autonomous individuality within the domestic sphere). 
vorce, ${ }^{366}$ nontraditional reproductive decisions, ${ }^{367}$ nonmarital families, ${ }^{368}$ and the proliferation of households without a stay-at-home parent $^{369}$ significantly change children's lives and, in turn, change conceptions of childhood. Faced with these changes, society has not been able to decide whether to treat children in traditional terms or in modern, individualist terms. The irresolution of society is pervasive, and so, in consequence, are the contradictions in law.

As the American family has increasingly diverged from the nineteenth- and early-twentieth-century conception of family, institutions that once served as ideological beacons, guiding individuals and society in the construction of domestic relationships, have eroded. In consequence, society turns more often to constitutional law to provide practical and moral guidance. Unfortunately, constitutional jurisprudence cannot resolve the social debate about family. It cannot explain how to preserve traditional understandings of childhood, which reflect a universe of status, while at the same time envisioning families (and especially adults within families) as collections of autonomous individuals.

American constitutional jurisprudence presumes autonomous individuality in protecting people's rights and ensuring equal treatment. ${ }^{370}$ In consequence, it cannot easily serve groups defined by status-as women and African Americans, for example, once were and as children still are. For such groups, legal protection almost inevitably becomes synonymous with paternalism. ${ }^{371}$ Whether the premise (that children are defined through their status) and its consequence (that they thus are not protected by rights afforded to autonomous individuals) are good or bad for children, in particular, raises a host of complicated questions. These

366. See, e.g., Eleanor E. Maccoby \& Robert H. Mnookin, Dividing the Child: Social and Legal Dilemmas of Custody 31-32 (1992) (exploring the impact of divorce on children); Judith Wallerstein et al., The Unexpected Legacy of Divorce: A 25 Year Landmark Study xxvii (2000) (same); Whitehead, supra note 4, at 7-8 (same).

367. See, e.g., Dolgin, Defining the Family, supra note 46, at 213-44 (considering consequences of reproductive technology for children).

368. See, e.g., Rubano, 759 A.2d at 977 (ruling on visitation rights of former same-sex domestic partner of child's biological mother).

369. See, e.g., Mintz \& Kellogg, supra note 13, at xiv, 218, 223, 240-42 (noting that between 1970 and 1983 the proportion of three- and four-year-old children in daycare centers or nursery schools almost doubled).

370. This is especially so with regard to the constitutional principles most often invoked in cases involving questions about family relationships. These most often include the Equal Protection and Due Process Clauses of the Fourteenth Amendment. See Rubin, supra note 1, at 4 (noting reliance on Equal Protection and Due Process Clauses in family litigation that invokes constitutional law). Kenneth Karst, among others, has described the Fourteenth Amendment as extending a "principle of equal citizenship." Kenneth L. Karst, Citizenship, Race, and Marginality, 30 Wm. \& Mary L. Rev. 1, 1 (1988).

371. Society has widely concluded that paternalism is misplaced and morally suspect with regard to most groups of adults, including women and ethnic or racial minorities. It has not reached a similar conclusion with regard to children, but it seems at times to be tempted. As Professor Steven Shiffrin declared, children are the "Achilles heel" of liberalism. Steven Shiffrin, Government Speech, 27 UCLA L. Rev. 565, 647 (1980). 
questions cannot be adequately addressed by a jurisprudence deeply committed to the protection of autonomous individuality.

The increasing reliance of family disputants and of the judiciary on constitutional principles to settle family disputes raises a host of additional problems. For the most part, family disputants raising federal constitutional questions invoke the Fourteenth Amendment's Due Process or Equal Protection Clauses. ${ }^{372}$ Both clauses presume to protect the autonomous individuality of those treated unjustly in a variety of contexts. Thus, in disputes that involve the meaning of childhood and the dimensions of the parent-child relationship, the Court has often been hesitant to apply constitutional rules directly to protect children's rights. ${ }^{373}$ In such cases, however, in order to avoid openly ignoring or disdaining the interests of children, the Court, as in Troxel, has often responded by explicitly presuming that children's interests are cared for by the family as a uni-

372. Some Supreme Court decisions involving children's rights have been decided on other grounds, including the First Amendment. See, e.g., Tinker v. Des Moines Indep. Cmty. Sch. Dist., 393 U.S. 503, 506 (1969) (affirming, in case involving First Amendment claim by high school students, that students do not "shed their constitutional rights to freedom of speech or expression at the schoolhouse gate").

373. See, e.g., Parham v. J.R., 442 U.S. 584, 620-21 (I979) (upholding state statute allowing parents to place their children in state mental hospitals); Wisconsin v. Yoder, 406 U.S. 205, 234-36 (1972) (invalidating, as applied to the Amish and without seeking views of children involved, a state law that required children to attend high school). Justice Douglas, however, dissented from the Court's opinion in Yoder insofar as that opinion, in his view, ignored the voices of the children involved. 406 U.S. at 243-46 (Douglas, J., dissenting). Justice Douglas characterized the Court's decision as threatening "the future of the student, not the future of the parents." Id. at 245 (Douglas, J., dissenting).

There are exceptions to the Court's reluctance to provide constitutional protection to children, but they have generally been qualified and thus easily distinguished. For instance, In re Gault extended constitutional protection to children involved in delinquency proceedings. 387 U.S. 1, 57-59 (1967). In deciding what the Due Process Clause required of juvenile delinquency proceedings, the Court appeared motivated by a desire to protect children. Id. at 17-21, 28 ("Under our Constitution, the state of being a boy does not justify a kangaroo court."). Thus, In re Gault can be read to safeguard the rights of a status group (minors) rather than the rights of children as autonomous individuals. See Bruce C. Hafen, Children's Liberation and the New Egalitarianism: Some Reservations About Abandoning Youth to Their "Rights," 1976 BYU L. Rev. 605, 656 [hereinafter Hafen, Children's Liberation] (noting that preservation of "authority," "responsibility," and "duty" within family settings is essential correlate to broad "individual tradition ... [in] American culture"). In fact, commentators and courts are still uncertain about the practical and theoretical implications of In re Gault and its progeny, including In $r e$ Winship, under which a twelve-year old was entitled to benefit of "proof beyond a reasonable doubt" standard before confinement for theft. 397 U.S. 358, 368 (1970).

The holding in In re Gault is clear. Less clear, however, are the implications of the decision for understandings of children as autonomous individuals or as members of a status group. See, e.g., Hafen, Children's Liberation, supra, at 632-35 (concluding that Court has "not rejected the validity of a legal minority status, although it is willing to provide constitutional protection against the abuse of that status"). Four years after the Court decided Gault, it limited the decision's reach hy holding that juveniles do not have the right to a jury trial in delinquency proceedings. McKeiver v. Pennsylvania, 403 U.S. 528,551 (197I). 
verse of status within which parents are obligated to-and in fact donurture and safeguard their children. To the extent that presumption is unwarranted, constitutional jurisprudence leaves children unprotected. Moreover, the presumption-again as illustrated in Troxel-precludes the law from heeding the interests of grandparents and siblings and denies the benefits such relatives can provide to many children, especially those not living in stable family settings.

Whatever constitutionalists conclude about the uses and abuses of substantive due process review as a jurisprudential tool, ${ }^{374}$ unenumerated rights (such as those of family members vis-à-vis each other and the state) cannot be adequately protected apart from a coherent conception of society within which the rights at issue are applicable. Troxel rests on no such conception. In consequence, it exacerbates the social confusions it seeks to untangle.

The confusion underlying Troxel's approach to the domestic arena reflects society's confusion. But Troxel seems intent on masking social confusion with a set of unsupported preferences and presumptions about contemporary families that are in large part belied by the Court's own assertion that traditional understandings of family no longer apply to most families. And so, however jurists ultimately assess substantive due process review, the Supreme Court, in applying constitutional rules to family disputes, does not possess either the jurisprudential tools or the sociological insight needed to safeguard children and to provide an ideological anchor around which society can test evolving visions of family.

To the extent that the Court's readiness to entertain Troxel is part of a developing understanding of children as autonomous individuals, Troxel reflects the Court's ambivalence about participating in that effort. By attempting to resolve family disputes about children through recourse to the Constitution without adequately understanding the contradictions between competing conceptions of the domestic sphere, the Justices serve neither the evolving American family nor the institution they constitute.

374. See supra note 139 (describing debate over substantive due process review). 